Prepared in cooperation with the County of Maui Department of Water Supply and the Pacific Regional Integrated Sciences and Assessments Program

\title{
Estimated Groundwater Recharge from a Water-Budget Model Incorporating Selected Climate Projections, Island of Maui, Hawai'i
}
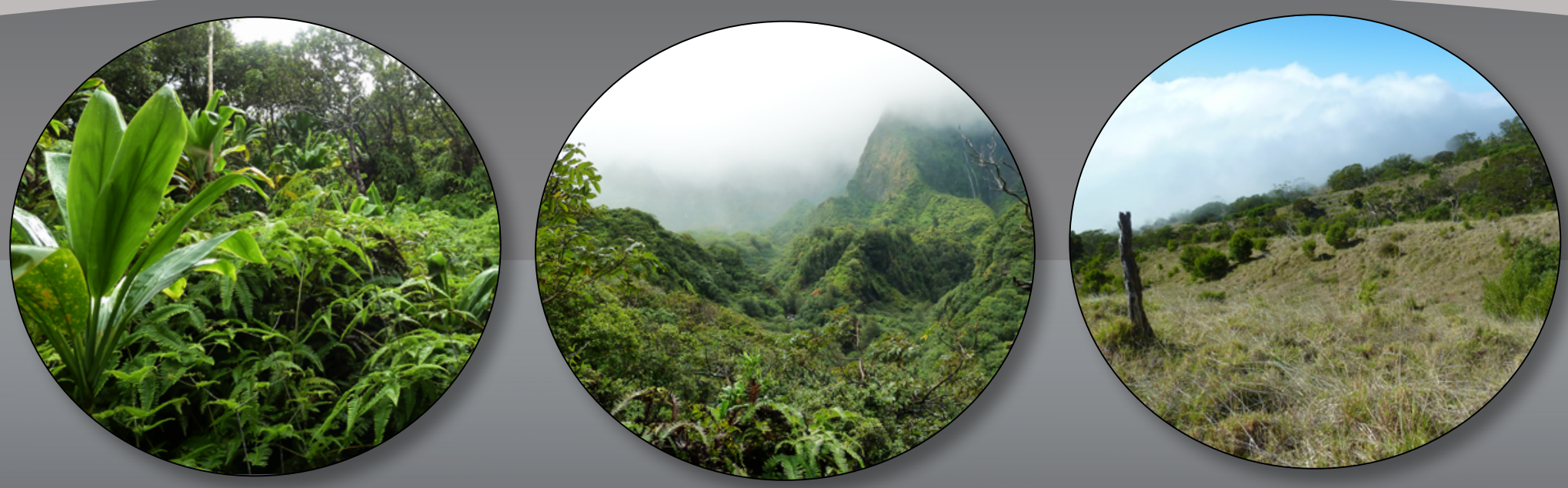

Scientific. Investigations Report 2019-5064

U.S. Department of the interior

U.S. Ceologicel Survey 
Cover. Left portal, Photograph of native forest in plateau near Kinihāpai Stream on eastern West Maui Mountain, Island of Maui, Hawaií. U.S. Geological Survey photograph by Alan Mair, December 2016. Center portal, Photograph of 'Tao Valley upland viewed from forested ridge near Kinihāpai Stream on eastern West Maui Mountain, Island of Maui, Hawai'i. U.S. Geological Survey photograph by Alan Mair, December 2016. Right portal, Photograph of Luala'ilua viewed from Wai'ōpae Gulch on southern Haleakalā, Island of Maui, Hawai'i. U.S. Geological Survey photograph by Joseph J. Kennedy, January 2018. Bottom, Photograph of Makamaka'ole Stream viewed from forest clearing near Kānoa Ridge on eastern West Maui Mountain, Island of Maui, Hawai'i. U.S. Geological Survey photograph by Alan Mair, December 2016. 


\section{Estimated Groundwater Recharge from a Water-Budget Model Incorporating Selected Climate Projections, Island of Maui, Hawai'i}

By Alan Mair, Adam G. Johnson, Kolja Rotzoll, and Delwyn S. Oki

Prepared in cooperation with the County of Maui Department of Water Supply and the

Pacific Regional Integrated Sciences and Assessments Program

Scientific Investigations Report 2019-5064 


\title{
U.S. Department of the Interior \\ DAVID BERNHARDT, Secretary
}

\author{
U.S. Geological Survey \\ James F. Reilly II, Director
}

U.S. Geological Survey, Reston, Virginia: 2019

For more information on the USGS—-the Federal source for science about the Earth, its natural and living resources, natural hazards, and the environment-visit https://www.usgs.gov or call 1-888-ASK-USGS.

For an overview of USGS information products, including maps, imagery, and publications, visit https://store.usgs.gov.

Any use of trade, firm, or product names is for descriptive purposes only and does not imply endorsement by the U.S. Government.

Although this information product, for the most part, is in the public domain, it also may contain copyrighted materials as noted in the text. Permission to reproduce copyrighted items must be secured from the copyright owner.

\section{Suggested citation:}

Mair, A., Johnson A.G., Rotzoll, Kolja, and Oki, D.S., 2019, Estimated groundwater recharge from a water-budget model incorporating selected climate projections, Island of Maui, Hawai'i: U.S. Geological Survey Scientific Investigations Report 2019-5064, 46 p., https://doi.org/10.3133/sir20195064.

ISSN 2328-0328 (online) 


\section{Acknowledgments}

This study was conducted in cooperation with the County of Maui Department of Water Supply and the Pacific Regional Integrated Sciences and Assessments (Pacific RISA) Program. The authors are grateful to the following people who contributed expertise and data to this study: Victoria Keener (East-West Center, Pacific RISA), Laura Brewington (East-West Center, Pacific RISA), Chunxi Zhang (University of Oklahoma), Oliver Elison Timm (State University of New York at Albany), Maoya Bassiouni (Oregon State University), Aly El-Kadi (University of Hawai'i at Mānoa), and Yuqing Wang (University of Hawai'i at Mānoa).

\section{Contents}

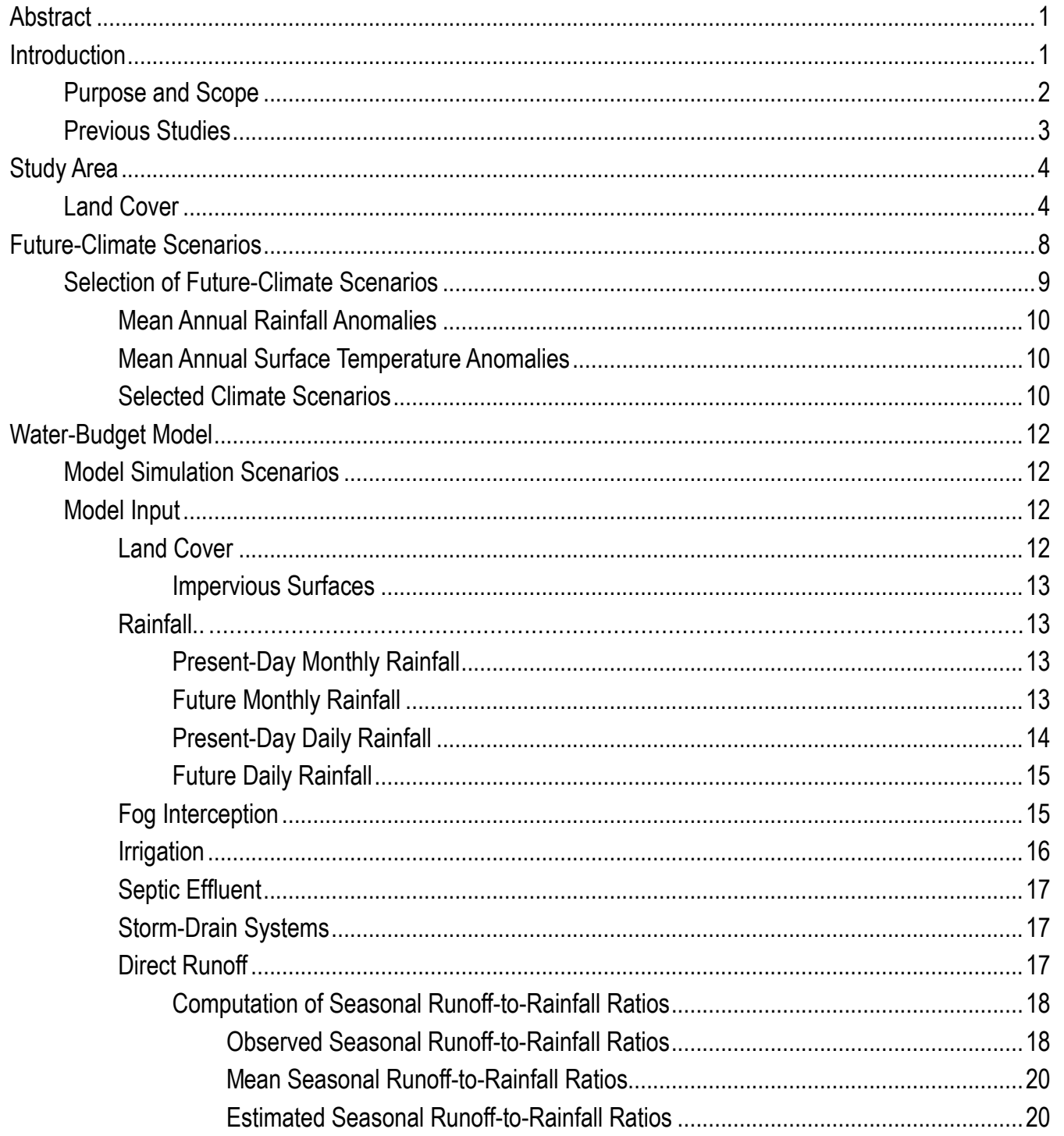




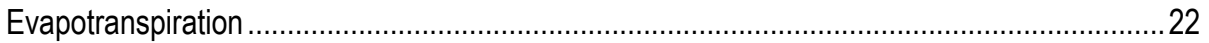

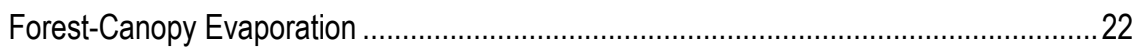

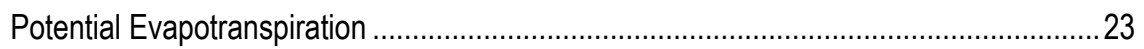

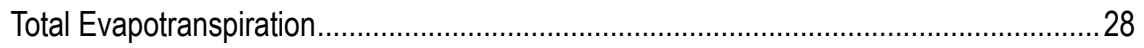

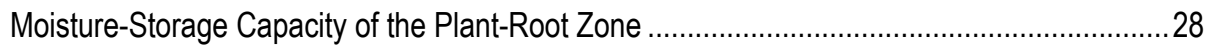

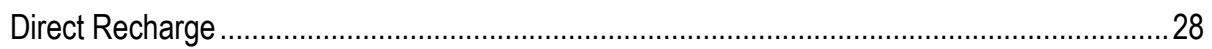

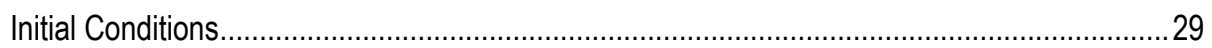

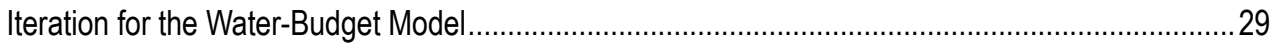

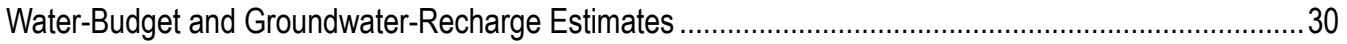

Water-Budget and Recharge Estimates for the 1978-2007 Present-Day Scenario ........................30

Water-Budget and Recharge Estimates for the SD RCP8.5 2071-99 Scenario ...............................30

Water-Budget and Recharge Estimates for the HRCM A1B 2080-99 Scenario............................... 37

Implications of Projected Changes on Groundwater Recharge ....................................................37

Assessing the Effects of Selected Climate Inputs on Estimated Recharge ......................................38

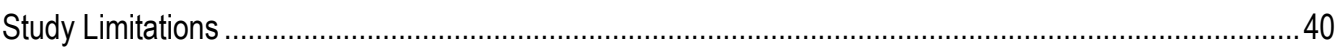

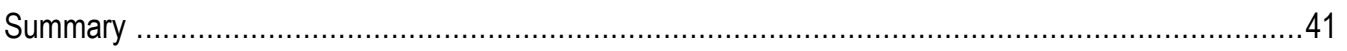

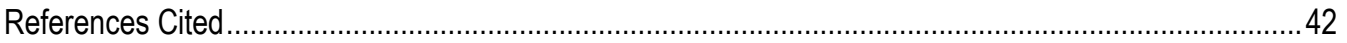

\section{Figures}

1. Map of aquifer systems and sectors, and major geographical features on the Island of Maui, Hawaili ..3

2. Map of major geographical features on the Island of Maui, Hawaili.

3. Map of mean annual rainfall (1978-2007) and locations of rain gages used in the water-budget calculations for the Island of Maui, Hawaili .....................................................................................

4. Map of land-cover classes for the Island of Maui, Hawaili, 2017 .......................................................7

5. Maps of projected mean annual rainfall anomalies of two future-climate scenarios for the Island of Maui, Hawai'i .

6. Maps of mean seasonal runoff-to-rainfall ratios for the Dry-season months: May through October and Wet-season months: November through April for drainage basins of selected stream-gaging stations and catchment zones on the Island of Maui, Hawaili.

7. Least-square fit curves of normalized rainfall and seasonal runoff-to-rainfall ratio values derived from 55 drainage basins on the islands of Kauai, O'ahu, and Maui

8. Projected anomaly map of the ratio of the mean evaporation rate to the mean precipitation rate during saturated conditions for the HRCM A1B 2080-99 scenario relative to the values from Johnson and others (2018) for the Island of Maui, Hawaii

9. Map of projected mean annual reference evapotranspiration anomalies computed for the HRCM A1B 2080-99 scenario, expressed as a fraction of the HRCM 1990-2009 simulation mean, for the Island of Maui, Hawai'i.

10. Graph of the absolute percentage change in island-wide recharge with each successive rechargemodel simulation for the Island of Maui, Hawaili

11. Map showing the distribution of mean annual groundwater recharge for present-day climate (1978-2007) and 2017 land-cover conditions for the Island of Maui, Hawaili..

12. Projected change in mean annual groundwater recharge for two future-climate scenarios for the Island of Maui, Hawai'i.

13. Projected change in mean annual groundwater recharge by aquifer system for two future-climate scenarios for the Island of Maui, Hawaii $i$ 


\section{Tables}

1. General types of land cover, as fraction of aquifer system area, Island of Maui, Hawaii i.

2. Summary of projected rainfall and temperature anomalies for available high-resolution down-scaled climate projections for the Island of Maui, Hawai'i.......

3. Periods of records used to compute observed seasonal runoff-to-rainfall ratios for drainage basins of selected stream-gaging stations in the study area on the Island of Maui, Hawaili, 1978-2007.

4. Coefficients for equation 7 that were used to estimate seasonal runoff-to-rainfall ratios for catchment zones on the islands of Kaua'i, O'ahu, and Maui, Hawai'i.

5. Land-cover parameters used in the water-budget calculations for study area on the Island of Maui, Hawaiii

6. Mean annual water-budget components from this study for aquifer systems and the Island of Maui, Hawai'i .....

7. Results of testing for selected water-budget model input parameters performed for selected aquifer systems and the Island of Maui, Hawai'i.......

\section{Conversion Factors}

U.S. customary units to International System of Units

\begin{tabular}{|c|c|c|}
\hline Multiply & By & To obtain \\
\hline \multicolumn{3}{|c|}{ Length } \\
\hline inch (in.) & 2.54 & centimeter $(\mathrm{cm})$ \\
\hline inch (in.) & 25.4 & millimeter $(\mathrm{mm})$ \\
\hline foot $(\mathrm{ft})$ & 0.3048 & meter $(\mathrm{m})$ \\
\hline mile (mi) & 1.609 & kilometer $(\mathrm{km})$ \\
\hline \multicolumn{3}{|c|}{ Area } \\
\hline acre & 4,047 & square meter $\left(\mathrm{m}^{2}\right)$ \\
\hline acre & 0.4047 & hectare (ha) \\
\hline square mile $\left(\mathrm{mi}^{2}\right)$ & 259.0 & hectare (ha) \\
\hline square mile $\left(\mathrm{mi}^{2}\right)$ & 2.590 & square kilometer $\left(\mathrm{km}^{2}\right)$ \\
\hline \multicolumn{3}{|c|}{ Volume } \\
\hline gallon (gal) & 3.785 & liter $(\mathrm{L})$ \\
\hline gallon (gal) & 0.003785 & cubic meter $\left(\mathrm{m}^{3}\right)$ \\
\hline million gallons (Mgal) & 3,785 & cubic meter $\left(\mathrm{m}^{3}\right)$ \\
\hline \multicolumn{3}{|c|}{ Flow rate } \\
\hline million gallons per day (Mgal/d) & 0.04381 & cubic meter per second $\left(\mathrm{m}^{3} / \mathrm{s}\right)$ \\
\hline \multicolumn{3}{|c|}{ Pressure } \\
\hline pound per square foot $\left(\mathrm{lb} / \mathrm{ft}^{2}\right)$ & 0.04788 & kilopascal (kPa) \\
\hline pound per square inch $\left(\mathrm{lb} / \mathrm{in}^{2}\right)$ & 6.895 & kilopascal (kPa) \\
\hline \multicolumn{3}{|c|}{ Energy } \\
\hline kilowatt-hour (kWh) & 3.6 & megajoule (MJ) \\
\hline
\end{tabular}

Temperature in degrees Celsius $\left({ }^{\circ} \mathrm{C}\right)$ may be converted to degrees Fahrenheit $\left({ }^{\circ} \mathrm{F}\right)$ as follows: ${ }^{\circ} \mathrm{F}=\left(1.8 \times{ }^{\circ} \mathrm{C}\right)+32$.

Temperature in degrees Fahrenheit $\left({ }^{\circ} \mathrm{F}\right)$ may be converted to degrees Celsius $\left({ }^{\circ} \mathrm{C}\right)$ as follows: ${ }^{\circ} \mathrm{C}=\left({ }^{\circ} \mathrm{F}-32\right) / 1.8$. 


\section{Datum}

Vertical coordinate information is referenced to local mean sea level.

Horizontal coordinate information is referenced to the North American Datum of 1983 (NAD 83).

Altitude, as used in this report, refers to distance above the vertical datum.

\section{Supplemental Information}

In this study, future projections of climate variables, such as rainfall, temperature, and reference evapotranspiration, are often described as either of two types of anomalies: (1) absolute anomaly, or (2) relative anomaly. An absolute anomaly is calculated as the difference between the projected future value and the value from a present-day condition, expressed in the units of the climate variable. A relative anomaly is calculated as the ratio of the absolute anomaly to the value from the present-day condition.

\section{Abbreviations}

$\begin{array}{ll}\text { CMIP } & \text { Coupled Model Intercomparison Project } \\ \text { CWRM } & \text { State of Hawai'i Commission on Water Resource Management } \\ \text { ET } & \text { evapotranspiration } \\ \text { FAO-PM } & \text { Food and Agriculture Organization of the United Nations Penman-Monteith } \\ \text { GCM } & \text { general circulation model } \\ \text { HRCM } & \text { Hawai'i Regional Climate Model } \\ \text { MDWS } & \text { County of Maui Department of Water Supply } \\ \text { OSDS } & \text { onsite disposal systems } \\ \text { Pacific RISA } & \text { Pacific Regional Integrated Sciences and Assessments } \\ \text { RCP } & \text { representative concentration pathway } \\ \text { RCM } & \text { regional climate model } \\ \text { SD } & \text { statistical downscaling } \\ \text { TMK } & \text { tax map key } \\ \text { USGS } & \text { U.S. Geological Survey }\end{array}$




\title{
Estimated Groundwater Recharge from a Water-Budget Model Incorporating Selected Climate Projections, Island of Maui, Hawai'i
}

\author{
By Alan Mair, Adam G. Johnson, Kolja Rotzoll, and Delwyn S. Oki
}

\section{Abstract}

Demand for freshwater on the Island of Maui is expected to increase by 45 percent between 2015 and 2035. Groundwater availability on Maui is affected by changes in climate and agricultural irrigation. To evaluate the availability of fresh groundwater under projected future climate conditions and changing agricultural irrigation practices, estimates of groundwater recharge are needed. A water-budget model with a daily computation interval was used to estimate the spatial distribution of recharge on Maui for one present-day and two future-climate scenarios. All three scenarios used 2017 land cover. The two future-climate scenarios, including one wetter than the present-day scenario and one drier than the presentday scenario, were developed using available high-resolution downscaled climate projections. The drier future scenario was developed using projections for a Representative Concentration Pathway warming scenario during 2071-99 with total radiative forcing of 8.5 Watts per square meter by the year 2100 (RCP8.5 2071-99 scenario), whereas the wetter future scenario was developed using projections for a "Special Report on Emissions Scenarios" A1B emission scenario during 2080-99 (A1B 2080-99 scenario). For the RCP8.5 2071-99 scenario, projected mean annual recharge decrease for Maui is about 172 million gallons per day, or about 14 percent less than present-day recharge, which is estimated to be 1,232 million gallons per day. Recharge for the RCP8.5 2071-99 scenario is projected to decrease in 22 of Maui's 25 aquifer systems, which are defined by the Hawai' $i$ Commission on Water Resource Management. For the A1B 2080-99 future scenario, projected mean annual recharge increase for Maui is about 144 million gallons per day, or about 12 percent more than present-day recharge. Recharge for the A1B 2080-99 scenario is projected to increase in 17 of Maui's 25 aquifer systems. Between the two future scenarios, a total of 11 aquifer systems show similar direction in drying (Kahului, Kama'ole, Luala'ilua, Makawao, Olowalu, Pā'ia, Ukumehame, Waikapū) or wetting (Honopou, Kawaipapa, and Waikamoi) changes for recharge. Selectively modifying the climate inputs for the A1B 2080-99 scenario indicates that the projected changes in rainfall account for most of the projected changes in recharge for Maui's 25 aquifer systems. However, projected changes in reference evapotranspiration and forestcanopy evaporation also can account for a substantial part of the projected changes in recharge where changes in reference evapotranspiration are relatively large and where changes in forest-canopy evaporation extend across large forested areas. Projected changes in daily rainfall frequency have a relatively small but non-negligible impact on recharge estimates.

\section{Introduction}

Groundwater provides 99 percent of Hawai 'i's drinking water and about 50 percent of all freshwater used in the State (Gingerich and Oki, 2000; Izuka and others, 2018). Groundwater availability in Hawai' $i$ is affected by changes in precipitation and evapotranspiration (ET), and vulnerable to saltwater intrusion related to withdrawals and contamination from anthropogenic sources (Hunt, 2004; Gingerich, 2008; Tribble, 2008; Izuka and others, 2018; Keener and others, 2018). Changes in climate can affect groundwater availability in Hawai'i mainly by influencing groundwater recharge rates. Groundwater recharge is water derived from precipitation and other sources, such as irrigation and leakage from septic systems, infiltrating the ground and replenishing aquifers. Recent studies have shown that observed changes in climate have already negatively affected groundwater resources in the Hawaiian Islands. Observed long-term downward trends of stream base flow (Oki, 2004; Bassiouni and Oki, 2013) are largely coincident with long-term downward trends of rainfall across more than 90 percent of the State (Frazier and Giambelluca, 2017) and upward trends of surface temperature, particularly at higher altitudes (Giambelluca and others, 2008; Diaz and others, 2011). These historical changes imply a decreasing trend in groundwater recharge and storage, and an overall decline in groundwater availability.

Two recent reports by the Intergovernmental Panel on Climate Change, the Fifth Assessment Report and the Special Report on Global Warming of $1.5^{\circ} \mathrm{C}$, have concluded that continued emissions of greenhouse gases will cause further warming and changes in all components of the Earth's climate system (Intergovernmental Panel on Climate Change, 2014; 2018). In response to the warming, General Circulation 
Model (GCM) projections indicate that changes in the water cycle will not be uniform and that contrasts in precipitation between wet and dry regions and wet and dry seasons will increase over the 21 st century. In the Hawaiian Islands, the interaction of prevailing northeast trade winds with the island chain's topography gives rise to a diversity of climate regimes on each island where mean annual rainfall for present-day climate conditions can vary by a factor of 15 or more across a distance of six miles or less (Schroeder, 1993; Giambelluca and others, 2013). Currently, many GCMs have a resolution of about 60 miles (mi) or greater (Taylor and others, 2012). Consequently, small-scale topographic features, such as the Hawaiian Islands, are below the typical horizontal and vertical resolution of many GCMs and cannot be represented in the GCMs (Timm and Diaz, 2009). High-resolution climate information is needed to incorporate fine-scale geographical variations and resolve their influence on Hawai'i's climate. To address the need for high-resolution climate information, dynamical and statistical downscaling methods have recently been used to post-process GCM results into mid- to late21 st century high-resolution climate-projection datasets for Maui and the other Hawaiian Islands (Elison Timm and others, 2015; Zhang and others, 2016a; 2016b; Elison Timm, 2017).

On Maui, the demand for freshwater derived from groundwater is projected to increase. Groundwater is the primary source of freshwater for the County of Maui Department of Water Supply (MDWS) and is a potential source for satisfying additional freshwater demand. Average daily water demand for MDWS is projected to increase by 45 percent from 2015 to 2035, from about 33.5 to 48.5 million gallons per day (Mgal/d) (County of Maui Department of Water Supply, 2016). The MDWS is updating its Water Use and Development Plan to include planning scenarios that address the impacts of population growth, land-use change, agricultural demand, drought, and climate change to identify and plan for future water needs and vulnerabilities (https://www.mauicounty.gov/2051/Maui-IslandWater-Use-Development-Plan). Quantifying the projected impacts of climate and land-cover change on groundwater availability is needed to provide critical information for future planning and management of water resources.

Closure of large sugar plantations on Maui in the 1980s and 1990s has corresponded with sharp declines in irrigation water use (Izuka and others, 2018). In 2010, a total of $285 \mathrm{Mgal} / \mathrm{d}$, or 87 percent of all freshwater withdrawn from groundwater and surface-water sources on Maui, was used for irrigation (see table 4 in Izuka and others, 2018). However, the last remaining sugarcane plantation on Maui ceased operation in December 2016 (Tanji, 2016), which implies that irrigation-water use in 2017 declined from 2010 levels. Changes in agricultural irrigation have affected the amount and distribution of groundwater recharge on Maui (Engott and Vana, 2007) and additional changes can affect groundwater levels and salinity (Gingerich, 2008).

Estimates of the spatial distribution of groundwater recharge for Maui are needed to evaluate the effects of projected changes in climate, decreased agricultural irrigation, and increased water demand on future groundwater availability.
Hydrologic models adapted to Hawai'i's diverse topography and climate have been developed to produce spatially distributed estimates of recharge rates on the Island of Maui and other parts of Hawai'i (Engott, 2011; Engott and others, 2017; Izuka and others, 2018; Johnson and others, 2018). Estimates of recharge are used by the State of Hawai' $i$ Commission on Water Resource Management (CWRM) in the calculation of sustainable-yield values for aquifer systems on Maui (fig. 1) and other parts of the State (Wilson Okamoto Corporation, 2008). Spatially distributed estimates of recharge are also a critical input to numerical groundwater models that can assess groundwater availability under different recharge and demand scenarios. Numerical groundwater models have been used to help inform decision making by MDWS and other water-resource managers in Hawai'i (Gingerich, 2008; Gingerich and Engott, 2012).

For this study, the water-budget model developed by Johnson and others (2018) was modified to estimate recharge for Maui for present-day and future climate conditions, assuming 2017 land-cover conditions. Two high-resolution downscaled climate-projection datasets were selected to capture the range of projected changes in island-wide rainfall for Maui. The recharge estimates from the climate-change scenarios in this study can be used in numerical groundwater models to evaluate the additional effects of groundwater withdrawals on groundwater levels, streamflow, coastal discharge, and salinities of water withdrawn from public and private wells on Maui.

\section{Purpose and Scope}

This report describes the spatial distribution of mean annual groundwater recharge for the Island of Maui for one present-day and two future-climate scenarios. Recharge was computed with a water-budget model that uses a daily computation interval (Johnson and others, 2018). Hydrological processes and physical conditions that affect recharge for present-day and future climate conditions were simulated in the water-budget model using the most recent datasets availableincluding maps of 2017 land-cover conditions, rainfall for each month during 1978-2007, and mean monthly reference grass evapotranspiration (ET) (Giambelluca and others, 2014; Frazier and others, 2016; Mair, 2018). Published high-resolution downscaled climate projections (Elison Timm and others, 2015; Zhang and others, 2016a; 2016b) were used to modify inputs of monthly rainfall, daily rainfall frequency, mean monthly reference ET, and forest-canopy evaporation for simulating the effects of future climate conditions on groundwater recharge and other water-budget components. The water-budget model and the input datasets for present-day and future climate conditions were used to estimate the spatial distribution of mean annual groundwater recharge for three water-budget model scenarios: (1) a 1978-2007 present-day scenario, (2) a Representative Concentration Pathway (RCP) warming scenario during 2071-99 with total radiative forcing of 8.5 Watts per square meter by the year 2100 (RCP8.5 2071-99 scenario), and (3) a "Special Report on Emissions Scenarios" A1B emission 


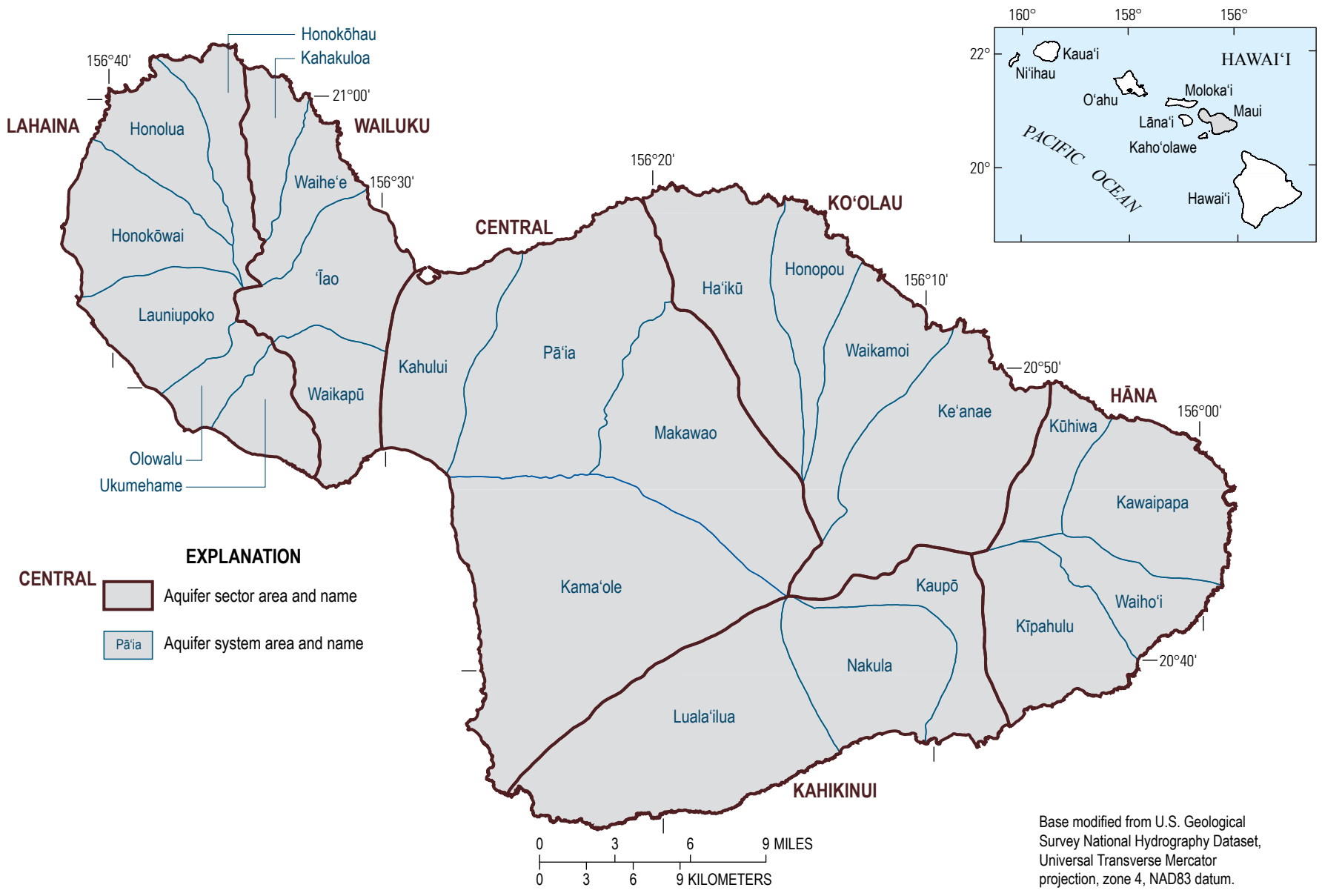

Figure 1. Map of aquifer systems and sectors, and major geographical features on the Island of Maui, Hawai'i (State of Hawai' $i$, 2010).

scenario during 2080-99 (A1B 2080-99 scenario). The RCP8.5 2071-99 scenario represents a future climate condition that is drier than the 1978-2007 present-day scenario, whereas the A1B 2080-99 scenario represents a future condition that is wetter than the 1978-2007 present-day scenario. A map of 2017 land cover was used in each of the water-budget model scenarios. The results of the water-budget model simulations were used to quantify the regional hydrologic changes between the present-day and future-climate scenarios. Finally, the effects of selectively changing inputs of monthly rainfall, daily rainfall frequency, mean monthly reference ET, and forestcanopy evaporation on recharge estimates for the A1B 2080-99 scenario were evaluated. Investigating the causes of differences in climate conditions among the published climate projections was beyond the scope of this study.

\section{Previous Studies}

The most recent estimates (as of 2019) of recharge for Maui were those of Johnson and others (2018) and Izuka and others (2018). Johnson and others (2018) developed a water-budget model with a daily computation interval to estimate mean annual recharge on Maui for 2010 land cover and two climate scenarios (1) average climate conditions (1978-2007 rainfall), and (2) drought conditions (1998-2002 rainfall). Izuka and others (2018) used the water-budget model of Johnson and others (2018) to estimate recharge on Maui for three sets of climate and land-cover scenarios (1) mean annual recharge for predevelopment conditions (1978-2007 rainfall and 1870 land cover), (2) mean annual recharge for average climate conditions (1978-2007 rainfall and 2010 land cover), and (3) annual recharge during 2001-10 (land cover and rainfall for 2001-10). The water-budget model results for average climate conditions from Izuka and others (2018) are equivalent to the results for average climate conditions from Johnson and others (2018). However, Izuka and others (2018) reported excess water captured by storm drains without distributing the water to runoff or recharge as done by Johnson and others (2018).

To the senior author's knowledge, no study has been published that documents climate-change impacts on groundwater recharge for Maui. Furthermore, no study has been published that compares climate-change effects to 
groundwater recharge in the Hawaiian Islands using highresolution downscaled projections of rainfall derived from more than one downscaling approach. Other studies have quantified how climate-change affects groundwater recharge and other water-budget components on the islands of $\mathrm{O}^{\prime} \mathrm{ahu}$ and Hawai'i using water-budget or watershed models and inputs derived from regional downscaled projections of rainfall and temperature and high-resolution downscaled projections of rainfall developed from a single downscaling approach (Engott, 2011; Safeeq and Fares, 2012; Leta and others, 2016; 2017; 2018; Strauch and others, 2017). Three of these studies quantified projected effects to groundwater recharge (Engott, 2011; Leta and others, 2016; 2017) as discussed below.

Engott (2011) used a water-budget model to simulate changes in groundwater recharge on the Island of Hawai' $i$ for a set of three climate-change scenarios that incorporated projections of late 21st-century rainfall (Timm and Diaz, 2009). Engott (2011) estimated rainfall-change factors based on the means, and the lower and upper margins of the 95-percent statistical confidence interval of rainfall anomalies reported by Timm and Diaz (2009). Engott (2011) reported that recharge estimates for the mean and upper 95-percent scenario were equal to or greater than baseline estimates for all but one of Hawai'i island's 24 aquifer systems. Recharge estimates for the lower 95-percent scenario were lower than baseline estimates for all but one aquifer system.

Leta and others (2016) used a watershed model to simulate changes in groundwater recharge and other water-budget components in the $\mathrm{He}$ 'eia watershed on the Island of $\mathrm{O}^{\prime} \mathrm{ahu}$ for a set of three climate scenarios that incorporated projections of atmospheric carbon dioxide $\left(\mathrm{CO}_{2}\right)$ concentrations, temperature, and rainfall (Intergovernmental Panel on Climate Change, 2007; Timm and Diaz, 2009; Diaz and others, 2011; Timm and others, 2011). In their first scenario, they found that a projected decrease of 10 percent in wet-season rainfall and a projected increase of 5 percent in dry-season rainfall resulted in a 7.3-percent decline in mean annual recharge. In a second scenario, projected changes in rainfall coupled with a $1.1^{\circ} \mathrm{C}$ increase in temperature resulted in a 10-percent decline in mean annual recharge. In their third scenario, projected changes in rainfall and temperature coupled with a 220 parts per million increase in atmospheric $\mathrm{CO}_{2}$ concentrations resulted in a 0.8 -percent decline in mean annual recharge.

Leta and others (2017) used a watershed model to simulate changes in groundwater recharge and other water-

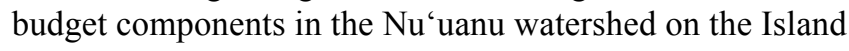
of O'ahu for a set of 48 climate scenarios that incorporated projections of solar radiation, temperature, and rainfall (Intergovernmental Panel on Climate Change, 2014; Elison Timm and others, 2015). For the scenarios incorporating only projected changes in rainfall, their results ranged from a 44-percent decrease to a 14-percent increase in mean monthly recharge. Scenarios that coupled projected changes in rainfall with projected changes in temperature resulted in changes in mean monthly recharge ranging from a 51-percent decrease to a 7.7-percent increase. Finally, scenarios that coupled projected changes in rainfall and temperature with projected changes in solar radiation resulted in changes in mean monthly recharge ranging from a 57-percent decrease to a 12-percent increase.

\section{Study Area}

The Island of Maui has an area of about 728 square miles and is divided into 6 aquifer sectors and 25 aquifer systems by CWRM for groundwater-management purposes (fig. 1). The island is formed by two shield volcanoes, the extinct West Maui Volcano known as West Maui Mountain and the dormant East Maui Volcano known as Haleakalā. An intervening saddle of broad, gently sloping land sits between the two volcanoes and is informally named the isthmus (fig. 2; Stearns and Macdonald, 1942; Macdonald and others, 1983). Erosion of West Maui Mountain has carved deep valleys resulting in sharp-crested ridges. On Haleakalā, the valleys on the rainy northeastern (windward) slope are separated by broad areas and ridges, whereas the drier southwestern (leeward) slope is less incised and retains the broad, shield shape of the volcano.

Mean annual rainfall varies widely from about 10 inches along the dry leeward shoreline of West Maui Mountain to over 400 inches along the wet windward slope of Haleakalā, and averages about 81 inches across the island (Giambelluca and others, 2013) (fig. 3). The seasonal rainfall cycle on Maui and other Hawaiian Islands is characterized by a dry and wet season. The dry season (May to September) is characterized by warm temperatures and steady trade winds, whereas the wet season (October to April) has cooler temperatures and less persistent trade winds (Blumenstock and Price, 1967; Sanderson, 1993). Areas in Hawai'i that frequently have fog are in the "cloud zone," which is between altitudes of about 2,000 and 8,200 feet (ft) (fig. 4; DeLay and Giambelluca, 2010). Detailed descriptions of Maui's climate, hydrogeology, surface water, and soils are provided in Johnson and others (2018) and Izuka and others (2018).

\section{Land Cover}

The diversity of land cover on Maui reflects the influence of steep climate gradients, agricultural practices, and land development (fig. 4). On West Maui Mountain, native forest and shrubland dominate the wet upland areas, whereas nonnative forest, grassland, urban development, and agricultural 


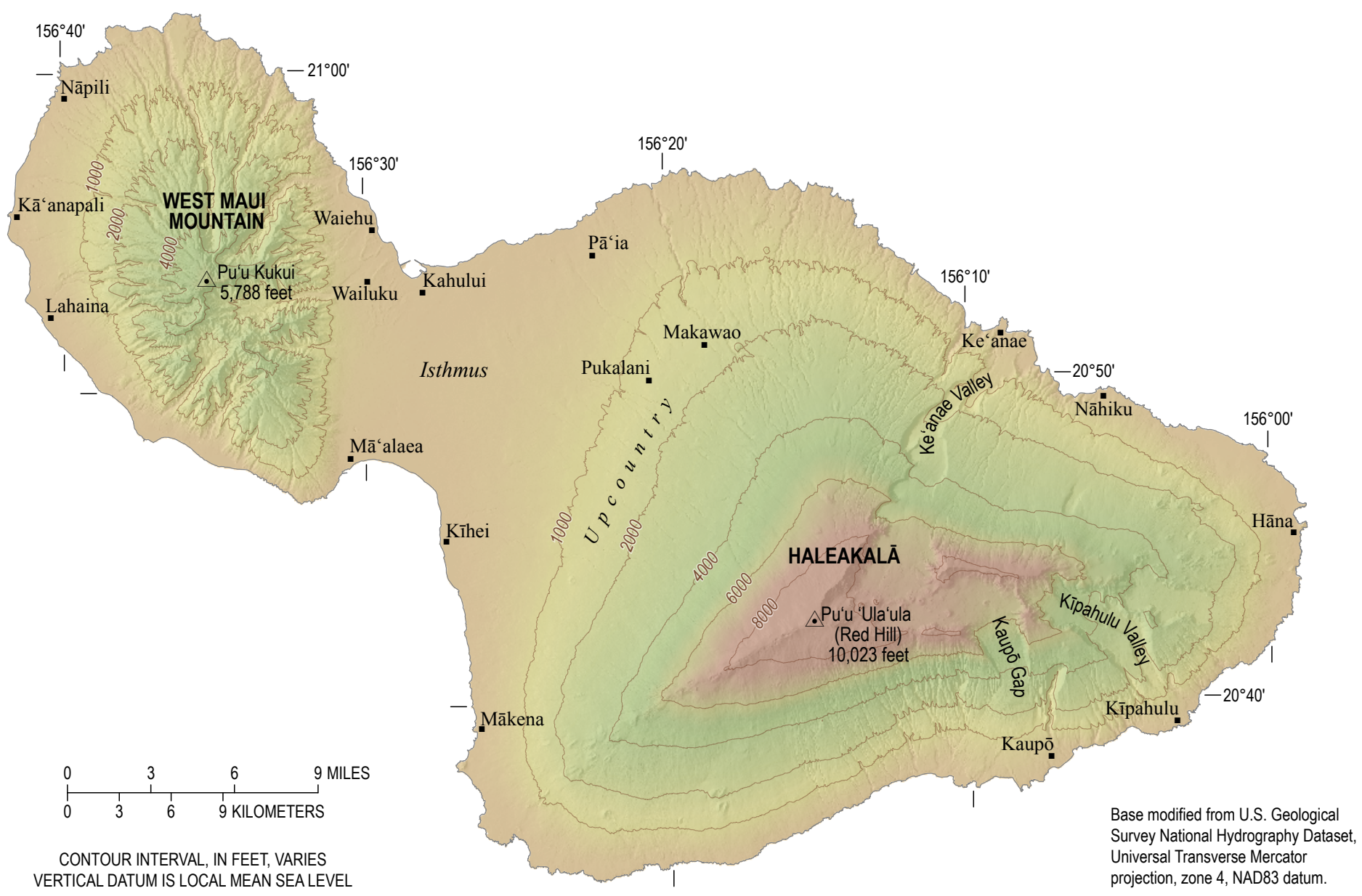

Figure 2. Map of major geographical features on the Island of Maui, Hawaii (from Johnson and others, 2018).

fields (macadamia and coffee) cover the drier lowland areas (U.S. Geological Survey, 2013). Mid-altitude areas on northwest Haleakalā are developed but also have patches of pineapple and diversified agriculture. In the high-altitude area of Haleakalā, sparsely vegetated barren rock is surrounded by a region of shrubland. Mostly native forest covers the mid-altitude wet northeastern slopes below the shrubland region and transitions to coastal regions dominated by non-native forest and grassland. Much of the arid southwestern slopes of Haleakalā are covered with non-native forest and grassland mixed with patches of development, native forest, and fields of pineapple and diversified agriculture. Coastal areas are developed near Lahaina, Kahului, Kỉhei, and Wailuku (fig. 2).
During most of the 20th century, sugarcane and pineapple fields covered large parts of the leeward slopes of West Maui Mountain (for example, Engott and Vana, 2007, fig. 2). Because of the cessation of these agricultural operations on West Maui Mountain, many of these fields are now grassland and shrubland. From the late 1800s to 2016, sugarcane fields covered much of the isthmus (Dorrance and Morgan, 2000; Tanji, 2016). However, because of the closure of the last remaining sugarcane plantation in December 2016, many of the fields in the isthmus area are now fallow or grassland. Since 2010, irrigated agriculture as a fraction of Maui's total land surface area has declined from nine percent (see table 2 in Johnson and others, 2018) to only one percent at the beginning of 2017 (table 1). 


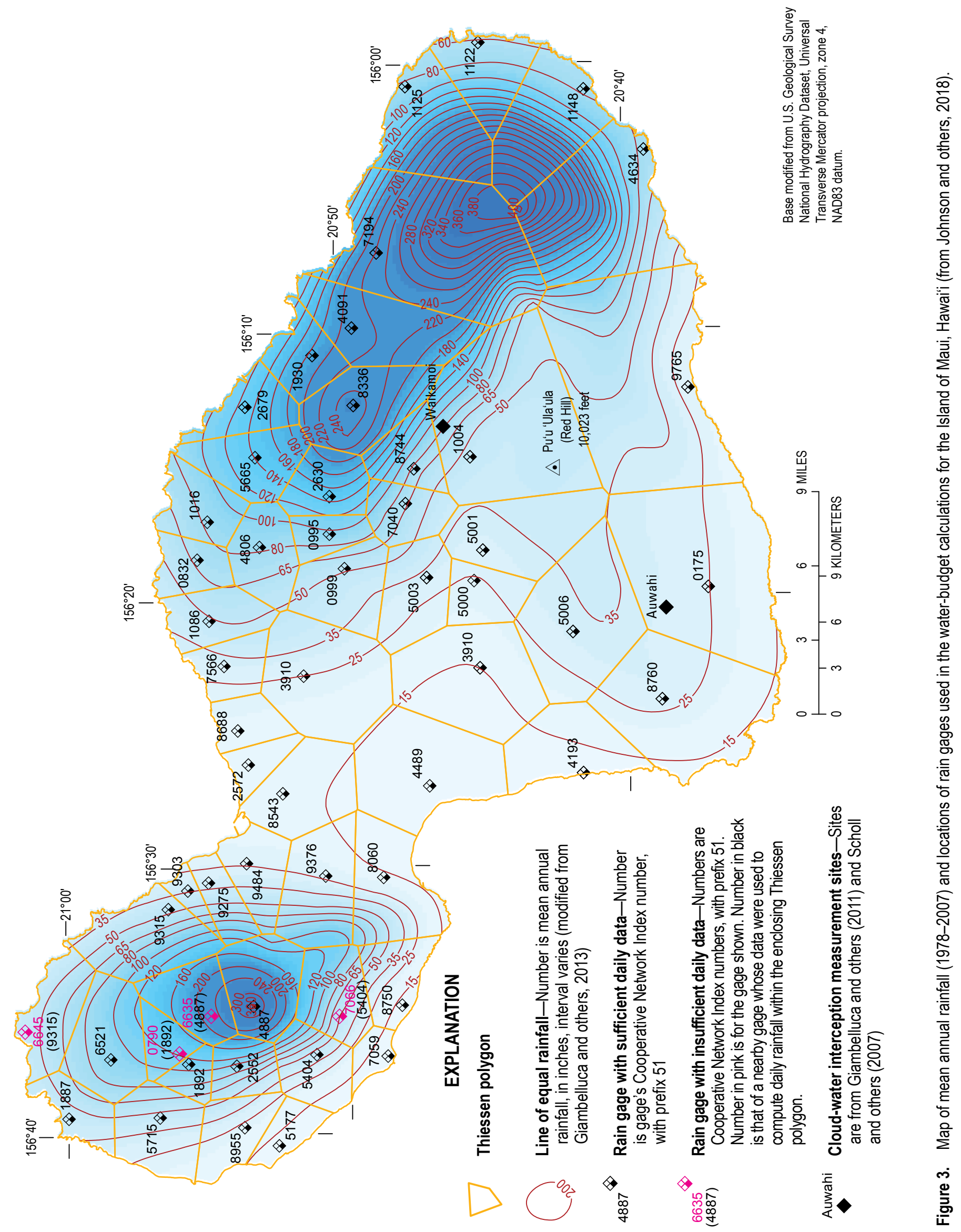




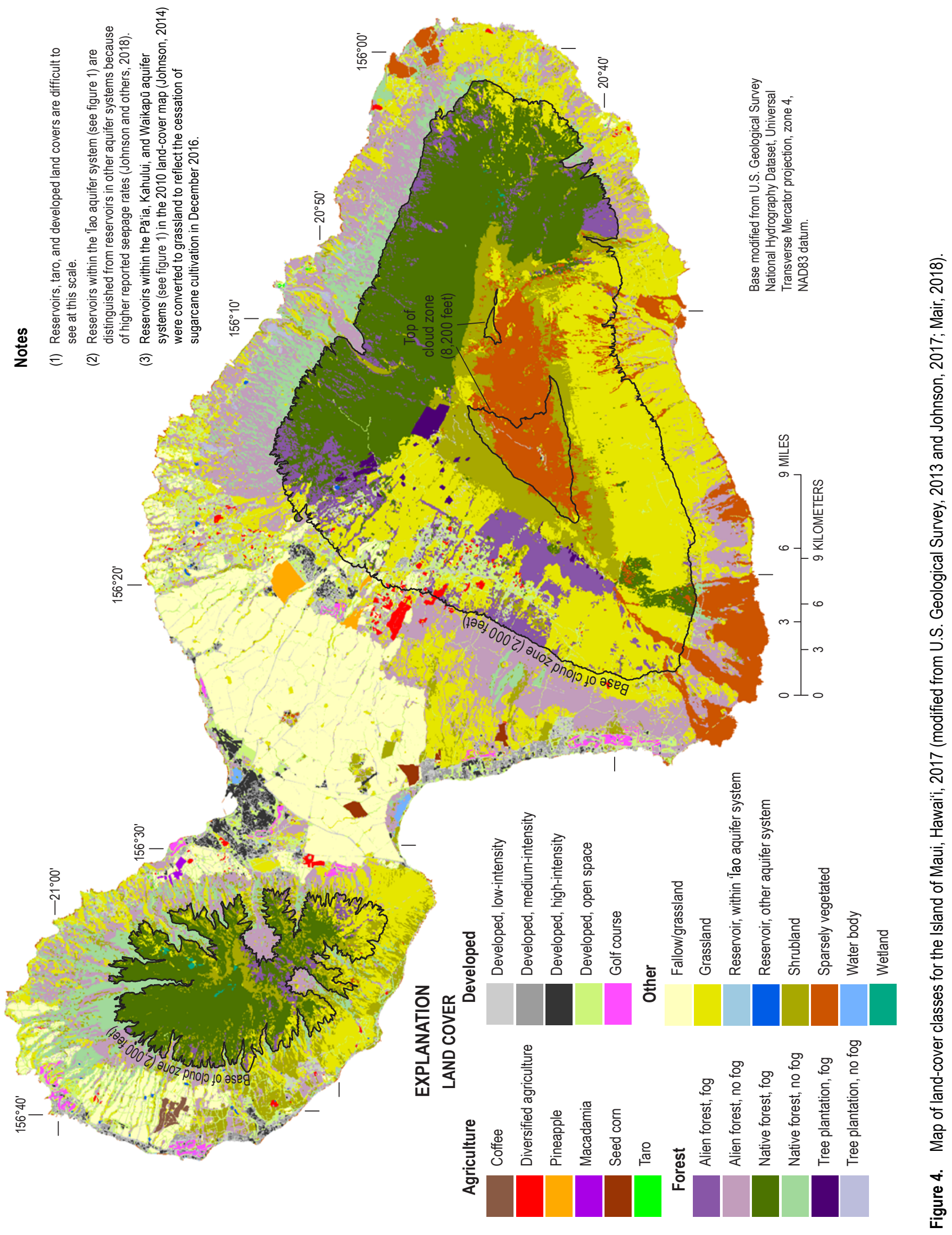


Table 1. General types of land cover, as fraction of aquifer system area, Island of Maui, Hawaili.

[Aquifer systems are illustrated in figure 1. Figure 4 shows geographic extent of land-cover classes. Agriculture - irrigated consists of the coffee, diversified agriculture, pineapple, seed corn, and taro land-cover classes; Other consists of the macadamia, reservoir, water body, and wetland land-cover classes. Sum of fraction for each aquifer system may not sum to one due to rounding.]

\begin{tabular}{|c|c|c|c|c|c|c|c|c|}
\hline Aquifer system & $\begin{array}{l}\text { Agriculture- } \\
\text { irrigated }\end{array}$ & $\begin{array}{l}\text { Developed } \\
\text { and } \\
\text { golf course }\end{array}$ & $\begin{array}{l}\text { Grassland } \\
\text { and fallow/ } \\
\text { grassland }\end{array}$ & Shrubland & $\begin{array}{l}\text { Alien forest } \\
\text { and tree } \\
\text { plantation }\end{array}$ & $\begin{array}{l}\text { Native } \\
\text { forest }\end{array}$ & $\begin{array}{l}\text { Sparsely } \\
\text { vegetated }\end{array}$ & Other \\
\hline Waikapū & 0.01 & 0.07 & 0.53 & 0.12 & 0.13 & 0.14 & 0.00 & 0.00 \\
\hline Waihe'e & 0.00 & 0.08 & 0.22 & 0.16 & 0.17 & 0.36 & 0.01 & 0.00 \\
\hline Kahakuloa & 0.00 & 0.02 & 0.13 & 0.06 & 0.25 & 0.53 & 0.00 & 0.01 \\
\hline Honolua & 0.00 & 0.23 & 0.19 & 0.03 & 0.17 & 0.38 & 0.00 & 0.00 \\
\hline Honokōwai & 0.04 & 0.23 & 0.27 & 0.10 & 0.14 & 0.23 & 0.00 & 0.01 \\
\hline Launiupoko & 0.00 & 0.15 & 0.18 & 0.27 & 0.10 & 0.29 & 0.00 & 0.00 \\
\hline Olowalu & 0.00 & 0.05 & 0.37 & 0.24 & 0.15 & 0.17 & 0.01 & 0.00 \\
\hline Ukumehame & 0.00 & 0.03 & 0.42 & 0.36 & 0.05 & 0.13 & 0.01 & 0.00 \\
\hline Kama'ole & 0.01 & 0.15 & 0.33 & 0.08 & 0.37 & 0.02 & 0.05 & 0.00 \\
\hline Ha'ikū & 0.01 & 0.22 & 0.29 & 0.01 & 0.31 & 0.16 & 0.00 & 0.00 \\
\hline Honopou & 0.00 & 0.10 & 0.14 & 0.01 & 0.43 & 0.32 & 0.01 & 0.00 \\
\hline Waikamoi & 0.00 & 0.02 & 0.04 & 0.08 & 0.26 & 0.59 & 0.00 & 0.00 \\
\hline $\mathrm{Ke}^{\prime}$ anae & 0.00 & 0.01 & 0.05 & 0.11 & 0.15 & 0.53 & 0.15 & 0.00 \\
\hline Kūhiwa & 0.00 & 0.02 & 0.07 & 0.03 & 0.35 & 0.52 & 0.00 & 0.00 \\
\hline Kawaipapa & 0.00 & 0.04 & 0.29 & 0.03 & 0.25 & 0.33 & 0.05 & 0.00 \\
\hline Waiho'i & 0.00 & 0.03 & 0.32 & 0.05 & 0.17 & 0.44 & 0.00 & 0.00 \\
\hline Kīpahulu & 0.00 & 0.02 & 0.18 & 0.10 & 0.21 & 0.47 & 0.01 & 0.00 \\
\hline
\end{tabular}

\section{Future-Climate Scenarios}

Recent downscaling of phases 3 and 5 of the Coupled Model Intercomparison Project (CMIP3 and CMIP5) model experiments using dynamical and statistical downscaling approaches has produced mid- and late-21st century highresolution climate projection datasets for the Hawaiian Islands (table 2) (Elison Timm and others, 2015; Zhang and others, 2016a; 2016b; Elison Timm, 2017). Elison Timm and others (2015) used a statistical downscaling (SD) approach to produce wet (November-April) and dry (May-October) season rainfall anomalies for two time periods (2041-71 and 2071-99) at a 250-meter grid spacing for two CMIP5 RCP scenarios with total radiative forcing of 4.5 and 8.5 Watts per square meter by the year 2100 (Intergovernmental Panel on
Climate Change, 2014), hereinafter SD RCP4.5 2041-71, SD RCP4.5 2071-99, SD RCP8.5 2041-71, and SD RCP8.5 2071-99 scenarios. The seasonal rainfall anomalies computed by Elison Timm and others (2015) represent departures from the mean seasonal rainfall amounts during 1978-2007 that were estimated by Giambelluca and others (2013). Elison Timm (2017) used a statistical downscaling approach to develop projections of ambient surface air temperature anomalies for two time periods (2040-69 and 2070-99) at a 250-meter grid spacing for RCP4.5 and RCP8.5 scenarios, hereinafter SD RCP4.5 2040-69, SD RCP4.5 2070-99, SD RCP8.5 2040-69, and SD RCP8.5 2070-99 scenarios. The ambient surface temperature anomalies for the RCP scenarios were computed relative to the mean values for a 1976-2005 reference period. 
Table 2. Summary of projected rainfall and temperature anomalies for available high-resolution down-scaled climate projections for the Island of Maui, Hawai'i.

[SD, statistical downscaling; RCP4.5 and RCP8.5, Representative Concentration Pathway with total radiative forcing of 4.5 and 8.5 Watts per square meter, respectively, by the year 2100; HRCM, Hawai' ${ }^{\prime}$ Regional Climate Model from Zhang and others (2016a; 2016b); A1B, A1B emission scenario from Intergovernmental Panel on Climate Change (2000); Temperature, air temperature at land surface; ${ }^{\circ} \mathrm{C}$, degrees Celsius]

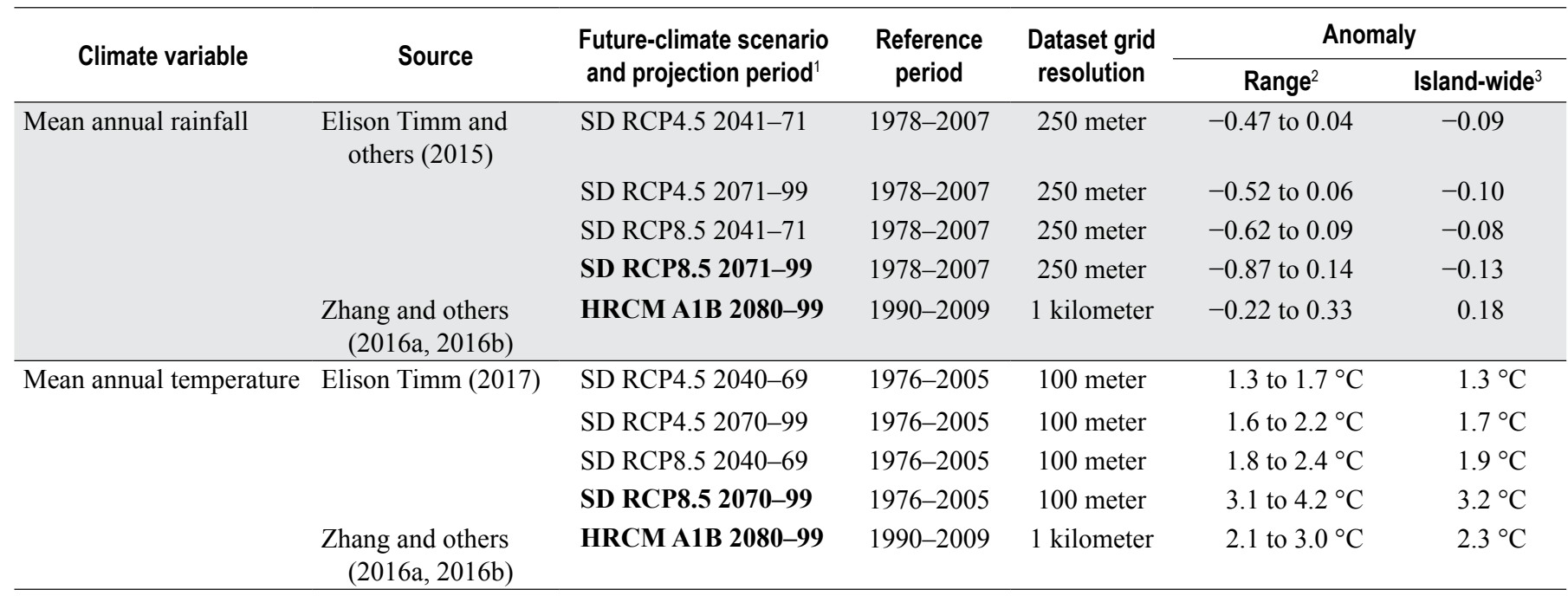

${ }^{1}$ The future climate scenarios selected for the water-budget simulations are shown in bold.

${ }^{2}$ For mean annual rainfall, anomaly expressed as a fraction of the reference period mean.

${ }^{3}$ For mean annual rainfall, computed as the area-weighted average of the product of the reference period mean and the mean annual anomaly at each cell of the atlas rainfall map for the Island of Maui by Giambelluca and others (2013) and then divided by the island-wide reference period mean.

Zhang and others (2012) used a dynamical downscaling approach by configuring a regional climate model for the main Hawaiian Islands and surrounding ocean region, hereinafter the Hawai' ${ }^{i}$ Regional Climate Model (HRCM), to conduct a one-year retrospective simulation (November 2005 to October 2006). Zhang and others (2012) used the HRCM to simulate the interaction of sea-surface temperature, cloudbase height, trade-wind strength and direction, and tradewind inversion height and frequency with Hawai'i's complex topography at a 3-kilometer $(\mathrm{km})$ grid spacing. The HRCM produced simulated meteorological parameters including rainfall, surface temperature, relative humidity, and wind speed and direction. Lauer and others (2013) noted limitations in the simulated rainfall of the HRCM over areas with steep topography, particularly on the islands of Maui and O'ahu. In response to these limitations, Zhang and others (2016a) modified the HRCM to include an additional nested domain at a 1-km grid spacing around Maui to further refine and improve the ability of the HRCM to simulate rainfall across steep and complex topography. They then used the modified HRCM to produce climate datasets for a 20 -year retrospective simulation of Maui during 1990-2009, hereinafter the HRCM 1990-2009 simulation. Zhang and others (2016b) used the modified HRCM to produce climate datasets of Maui for a CMIP3 "Special Report on Emissions Scenarios" (SRES) A1B emission scenario (Intergovernmental Panel on Climate Change, 2000) during 2080-99, hereinafter the HRCM A1B 2080-99 scenario.
The A1B scenario is a global emission scenario characterized by very rapid global economic growth, global population that peaks in mid-century, rapid introduction of more efficient technologies, and a balanced dependence on fossil and nonfossil intensive energy sources (Intergovernmental Panel on Climate Change, 2000). In terms of projected global $\mathrm{CO}_{2}$ emissions for 2100, the A1B scenario ranks as a mid-level projection among the SRES emission scenarios. In 2014, the Intergovernmental Panel on Climate Change adopted a new approach for defining future scenarios to support research on potential policy responses to climate change, which resulted in the RCP set of greenhouse gas concentration scenarios (Intergovernmental Panel on Climate Change, 2014). The RCP scenarios describe different pathways of greenhouse gas emissions and atmospheric concentrations, air pollutant emissions, and land use. The RCP8.5 scenario is characterized by increasing greenhouse gas emissions over time that lead to high greenhouse gas concentration levels. Among the total set of RCP scenarios, the RCP 8.5 corresponds to the pathway with the highest greenhouse gas emissions.

\section{Selection of Future-Climate Scenarios}

For this study, the high-resolution downscaled climate projection datasets were reviewed to select a total of two futureclimate scenarios for the water-budget model analyses. Projected 
mean annual rainfall and temperature anomalies for each dataset were computed and compared to determine the range of projected changes in rainfall and temperature. On the basis of projected changes in mean annual rainfall, two climate projections were chosen to capture a range of future climate conditions.

\section{Mean Annual Rainfall Anomalies}

The projected wet- and dry-season rainfall anomalies for the RCP scenarios were transformed into mean annual rainfall anomalies to allow for comparisons of future climate projections across annual hydrologic cycles for Maui. The seasonal rainfall anomalies developed by Elison Timm and others (2015) are available as geospatial datasets: (1) relative seasonal rainfall anomalies expressed as a fraction of a present-day mean, (2) absolute seasonal rainfall anomalies expressed in units of millimeters $(\mathrm{mm})$ above or below the present-day mean, and (3) absolute seasonal rainfall anomalies expressed in units of inches above or below the present-day mean. These datasets were obtained from the State University of New York at Albany (see data product labeled SDSRA-HI-V2 at http://www.atmos. albany.edu/facstaff/timm/products_data.html). First, absolute mean annual rainfall anomalies, expressed in units of $\mathrm{mm}$ above or below the present-day mean, were computed as the sum of wet- and dry-season rainfall anomalies at each grid cell. Next, relative mean annual rainfall anomalies, expressed as a fraction of a present-day mean, were computed by dividing the absolute mean annual rainfall anomalies by the mean annual rainfall grid values developed by Giambelluca and others (2013) for 1978-2007. Mean annual rainfall during 1978-2007 (Giambelluca and others, 2013) was used as the present-day mean because the future wetand dry-season rainfall anomalies by Elison Timm and others (2015) were computed relative to the same 1978-2007 period.

The retrospective simulations and climate projections developed by Zhang and others (2016a; 2016b) were also transformed into mean annual rainfall anomalies for Maui. Gridded, geospatial datasets of daily rainfall produced by Zhang and others (2016a; 2016b) for the HRCM 1990-2009 simulation and HRCM A1B 2080-99 scenario were provided by the University of Hawai' $i$ at Mānoa (HRCM monthly rainfall data available at http://apdrc.soest.hawaii.edu/projects/HRCM/). First, mean annual rainfall values were computed for each grid cell of the HRCM 1990-2009 simulation and HRCM A1B 2080-99 scenario. Next, absolute mean annual rainfall anomalies, which are expressed in $\mathrm{mm}$, were computed as the difference between the mean annual rainfall of the HRCM A1B 2080-99 scenario and the HRCM 1990-2009 simulation for each grid cell. The relative mean annual rainfall anomalies, expressed as a fraction of the 1990-2009 mean, were then computed by dividing the absolute mean rainfall anomalies by the HRCM 1990-2009 simulation mean at each grid cell. Projected changes in island-wide mean annual rainfall vary from a 13 percent decrease for the SD RCP8.5 2071-99 scenario to an 18 percent increase for the HRCM A1B 2080-99 scenario (table 2).

The wet- and dry-season rainfall anomalies for the SD RCP8.5 2071-99 scenario (Elison Timm and others, 2015) were developed relative to mean rainfall during 1978-2007 (Giambelluca and others, 2013). However, the climate projections for the HRCM A1B 2080-99 scenario (Zhang and others, 2016b) were developed relative to simulated climate conditions during 1990-2009 (Zhang and others, 2016a). For this study, an approach was developed to establish a common reference period for the rainfall projections for the SD RCP8.5 2071-99 and HRCM A1B 2080-99 scenarios (see Future Monthly Rainfall section).

\section{Mean Annual Surface Temperature Anomalies}

Datasets of the mean annual surface air temperature anomalies developed by Elison Timm (2017) for the RCP scenarios were obtained from the State University of New York at Albany (see data product labeled Version 1.1 at http://www.atmos. albany.edu/facstaff/timm/products data.html). The HRCM 19902009 simulation and HRCM A1B $2080-99$ scenario projection developed by Zhang and others (2016a; 2016b) were transformed into mean annual surface air temperature anomalies to allow for comparison with the surface air temperature anomalies developed by Elison Timm (2017) for the RCP scenarios. First, mean annual surface air temperatures for the HRCM 1990-2009 simulation and HRCM A1B 2080-99 scenario were computed for each grid cell using simulated hourly data of surface air temperature at a height of 2 meters (m) (above the land surface) developed by Zhang and others (2016a; 2016b) and provided by the University of Hawai' ${ }^{i}$ at Mānoa (see HRCM data products at http://apdrc.soest.hawaii. edu/projects/HRCM/). Next, mean annual temperature anomalies for the HRCM A1B 2080-99 scenario were computed as the difference between the future mean and the 1990-2009 mean for each grid cell. The range of projected warming varies from 1.3 to 1.7 degrees Celsius $\left({ }^{\circ} \mathrm{C}\right)$ for a SD RCP4.5 2040-69 scenario to 3.1 to $4.2^{\circ} \mathrm{C}$ for a SD RCP8.5 2070-99 scenario (table 2). The range of projected warming for the HRCM A1B 2080-99 scenario is within the range of projected warming for the four RCP scenarios (SD RCP4.5 2040-69, SD RCP4.5 2070-99, SD RCP8.5 2040-69, and SD RCP8.5 2070-99). All scenarios project greater rates of warming at higher altitudes.

\section{Selected Climate Scenarios}

All future-climate scenarios project drying across much of central and leeward Maui along with wetting across parts of the windward slopes of Haleakalā (not shown). The greatest drying occurs near the coastline along the southern part of the Kama'ole aquifer system where mean annual rainfall is projected to decrease by more than 80 percent for a SD RCP8.5 2071-99 scenario (fig. 5). The greatest wetting occurs along parts of the southeast slope of Haleakalā where mean annual rainfall is projected to increase by as much as 33 percent for the HRCM A1B 2080-99 scenario (fig. 5). However, these two future scenarios indicate contrasting drying and wetting for many parts of Maui including the windward areas of west Maui, high-altitude windward areas of Haleakalā, and the southeast areas of Haleakalā. In these areas, projected changes in mean rainfall for the SD RCP8.5 2071-99 


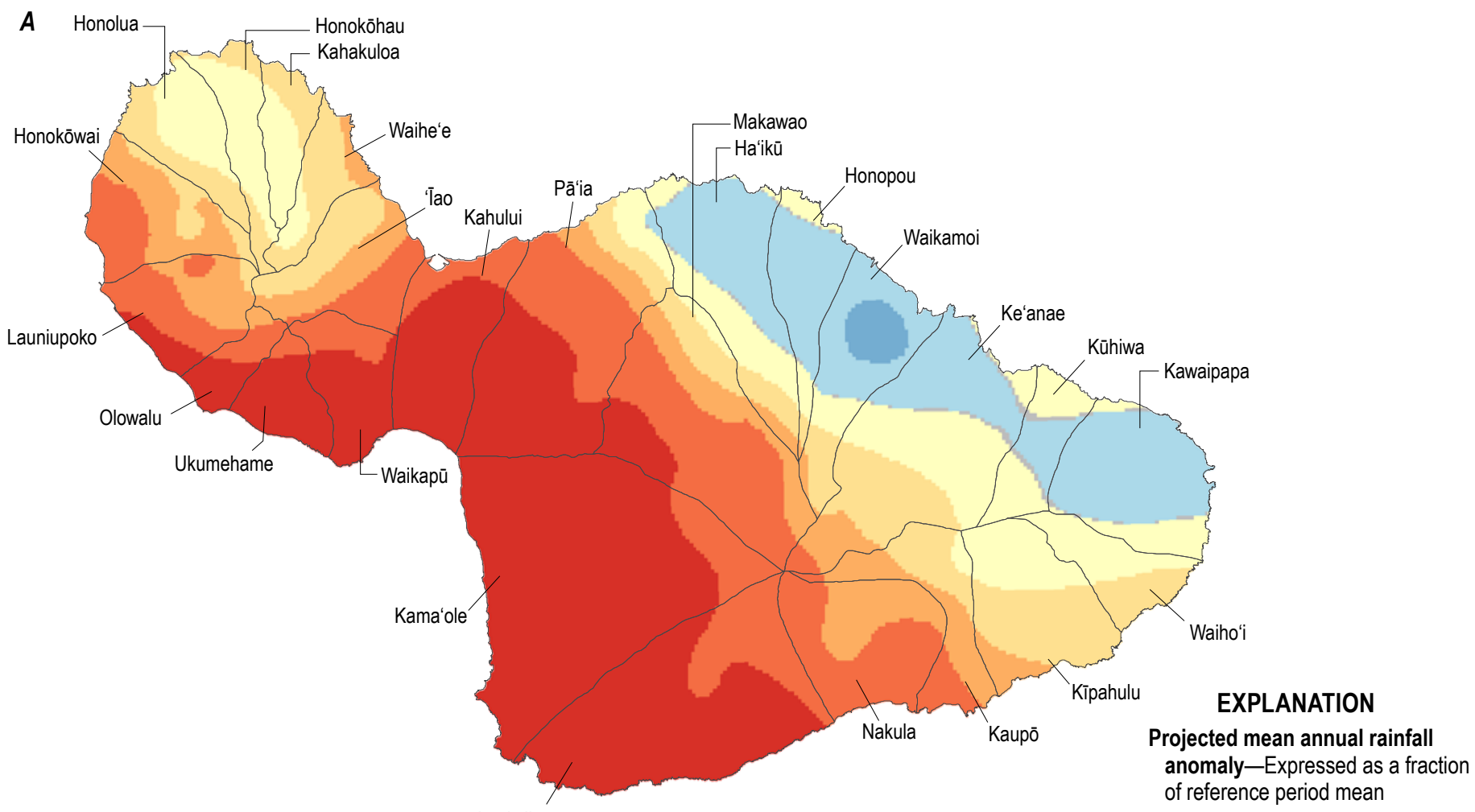

B

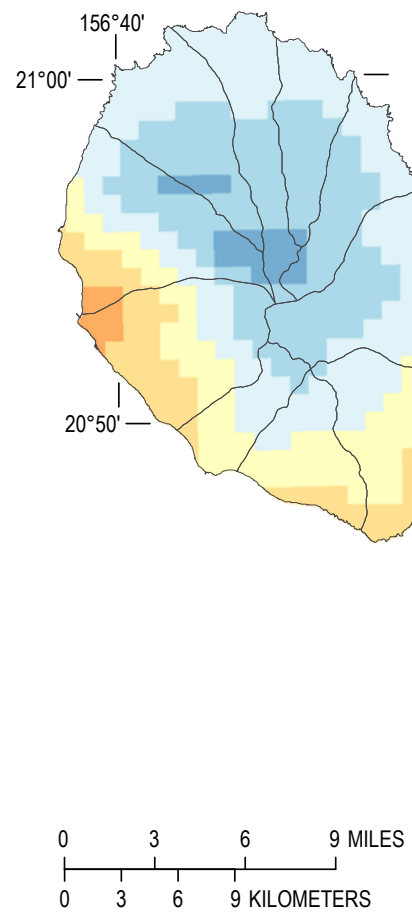

Luala'ilua

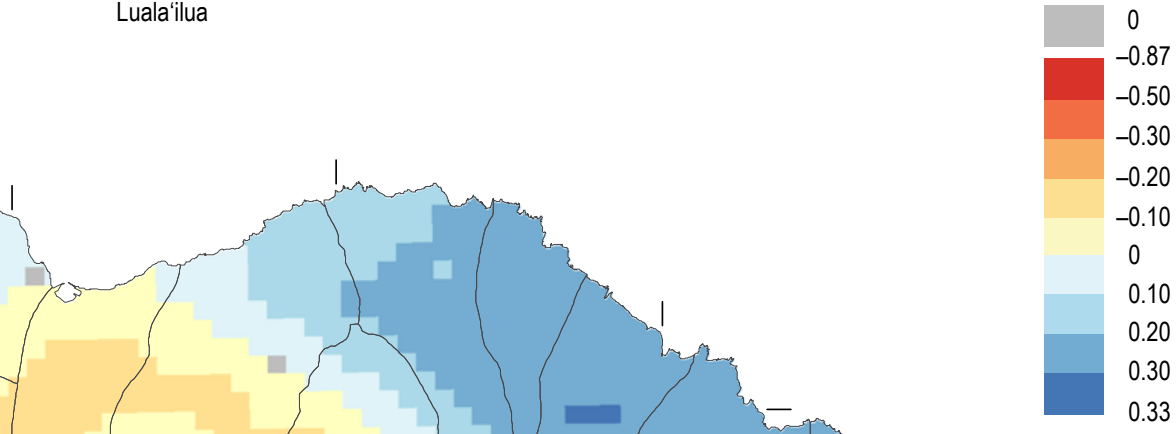

Universal Transverse Mercator projection, zone 4, NAD83 datum

$6^{\circ} 30^{\prime}$
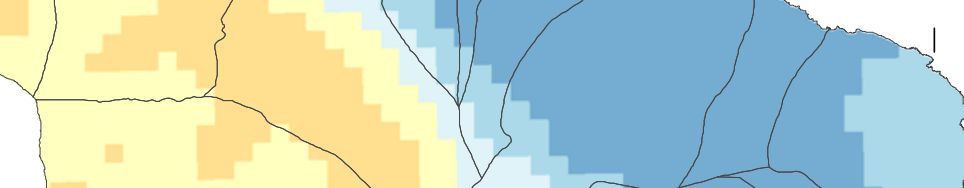

Boundary of aquifer system

(State of Hawai'i, 2010)

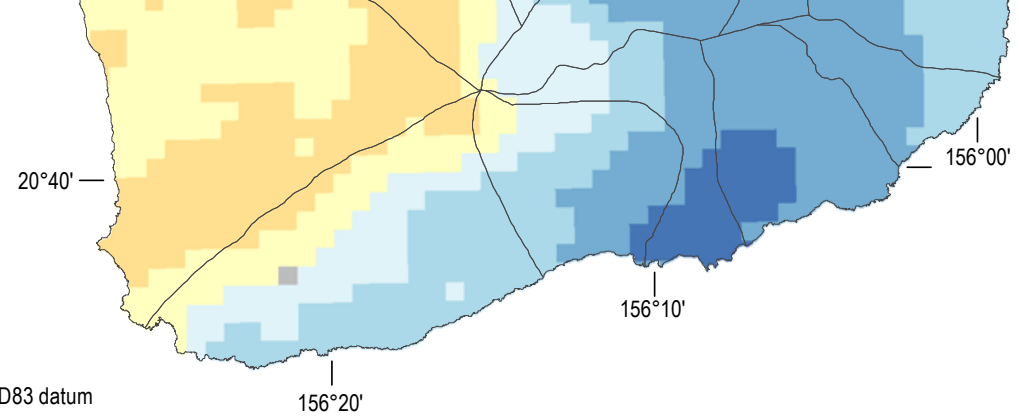

Figure 5. Maps of projected mean annual rainfall anomalies of two future-climate scenarios for the Island of Maui, Hawai'i. (A) SD RCP8.5 2071-99 scenario from Elison Timm and others (2015), (B) HRCM A1B 2080-99 scenario from Zhang and others (2016b). Projected anomalies for the SD RCP8.5 2071-99 scenario are relative to mean annual rainfall during 1978-2007 from Giambelluca and others (2013); projected anomalies for the HRCM A1B 2080-99 scenario are relative to mean annual rainfall during a 1990-2009 retrospective simulation from Zhang and others (2016a). 
scenario show a drying in contrast to a wetting for the HRCM A1B 2080-99 scenario. The contrasts in rainfall changes (in both magnitude and direction) across many parts of Maui reflect uncertainty in projected late-21st century rainfall (fig. 5). Part of the contrasting rainfall changes may also be related to the use of different present-day reference datasets for each of the futureclimate scenarios: (1) 1978-2007 seasonal rainfall for the SD RCP8.5 2071-99 scenario, and (2) HRCM 1990-2009 simulation rainfall for the HRCM A1B 2080-99 scenario. Projected changes in mean annual temperature for the SD RCP8.5 2070-99 and HRCM A1B 2080-99 scenarios indicate warming across all of Maui with more rapid warming at higher altitudes (not shown). Assessing the causes of differences in change direction and magnitude for future projections of rainfall and temperature is beyond the scope of this study.

For this study, two future-climate scenarios were selected for quantifying possible changes in groundwater recharge using a water-budget model: (1) SD RCP8.5 2071-99 scenario, and (2) HRCM A1B 2080-99 scenario. These two scenarios were chosen because they capture the range of projected changes in island-wide rainfall among the set of available climate projections for the mid- and late-21st century (table 2). The SD RCP8.5 2071-99 scenario represents the driest scenario among the available set of rainfall projections, whereas the HRCM A1B 2080-99 scenario represents the wettest scenario. The projected rates of warming across Maui were not considered in the selection of the future-climate scenarios.

\section{Water-Budget Model}

Groundwater recharge replenishes aquifers and is fed mainly by precipitation and irrigation that infiltrates the ground surface and percolates beyond the root zone in the soil. For this study, we estimated spatially distributed mean annual groundwater recharge on Maui by using a water-budget model. The water-budget model is designed to simulate — on a daily basis - the hydrologic processes and physical conditions that affect recharge on Maui. Hydrologic processes simulated by the model include rainfall, fog interception, irrigation, runoff, and ET. The model represents physical conditions by using parameters that include the moisture-storage capacity of soils and properties of the vegetation and land cover that affect ET. For each model subarea (see Land Cover section), the waterbudget model calculates recharge and other water-budget components on a daily basis during the simulation period.

The water-budget model used for this study is a modified version of the model used for a previous U.S. Geological Survey (USGS) recharge study for Maui (Johnson and others, 2018). Detailed descriptions of the water-budget model, the calculations performed by the model, and the model exclusions and limitations are provided in Johnson and others (2018) and Izuka and others (2018). The structure of the model used for this study is similar to the model developed by Johnson and others (2018). However, the model used for this study differs from the previous study by incorporating (1) a land-cover map for Maui representative of 2017 conditions, (2) estimates of the temporal distribution of direct runoff, and (3) high-resolution downscaled climate projections representing two selected future climate conditions.

The water-budget model used for this study is similar to other models that simulate a root-zone water balance and can be used to estimate recharge (for example, Leavesley and others, 1983; Hevesi and others, 2002; Westenbroek and others, 2010; 2018). Westenbroek and others (2018) used their model in a pilot application for Maui; however, their model was not available in time for this study. For this study, the preferred approach was to build on the previous water-budget model developed by Johnson and others (2018) for Maui because (1) the model is better adapted to conditions unique to Maui, such as a persistent fog and cloud cover for many locations and a pronounced orographic influence on climate, and (2) a high degree of spatial detail is needed for defining the model subareas. The model is a "threshold-type" or "reservoir" model utilizing a variation of the Thornthwaite and Mather (1955) mass-balance procedure. The high degree of spatial detail allows the model to represent the wide range of climate conditions, vegetation, soils, and land cover on Maui.

\section{Model Simulation Scenarios}

In this study, we selected three water-budget model simulation scenarios: (1) average climate conditions during 1978-2007, hereinafter the 1978-2007 present-day scenario, (2) projected rainfall conditions for an SD RCP8.5 2071-99 scenario, and (3) projected climate conditions for an HRCM A1B 2080-99 scenario. A 30-year simulation period was used for each of the three water-budget scenarios. The mean annual recharge of each scenario was determined for each model subarea. Mean annual recharge for each of Maui's 25 aquifer systems and the Island of Maui was calculated by summing the values of the model subareas located within their respective boundaries.

\section{Model Input}

This study incorporates a separate set of model input datasets to characterize rainfall, direct runoff, and ET for each water-budget simulation scenario. For the remaining model inputs, a common set of model input datasets was used in all three water-budget model simulation scenarios that included, but was not limited to, datasets used to characterize land-cover conditions, soil moisturestorage capacities, fog-interception rates, irrigation methods, septic effluent, and storm-drain capture.

\section{Land Cover}

The 2017 land-cover map (fig. 4) is a modified version of the 2010 land-cover map by Johnson (2017). The 2010 land-cover map was used to define the subareas for the waterbudget model developed by Johnson and others (2018). The polygon structure of the 2010 land-cover map was generated 
by intersecting (merging) multiple spatial datasets that characterize the spatial distribution of rainfall, cloud-water (or fog) interception, irrigation, reference ET, direct runoff, soil type, and land cover. The 2017 land-cover map retains the merged structure of the 2010 land-cover map but includes modifications mainly related to changes in agriculture since 2010. Modifications to the 2010 land-cover map include updates to the land-cover class and vegetation designations and to the polygon boundaries in the 2010 land-cover map to reflect (1) the cessation of sugarcane cultivation by Hawaiian Commercial \& Sugar Company in December 2016, and (2) the agricultural land-use information described in the Statewide Agricultural Land Use Baseline 2015 map by Melrose and others (2016). These modifications affected about 10 percent of the total area in the 2010 land-cover map. The 2017 land-cover map contains 505,294 subareas with an average area of about 0.9 acres (fig. 4). A fallow/grassland land-cover classification was assigned to subareas of the sugarcane land-cover class in Melrose and others (2016). The 2017 land-cover map also distinguishes between (1) forested areas that are within the fog-interception zone, assumed to be at altitudes of 2,000 feet and higher on Maui, and (2) forested areas that are below the fog-interception zone. The same distinction was included in the analysis of Johnson and others (2018) and in the spatial structure of the 2010 land-cover map but was omitted from the land-cover names in the attribute table of the 2010 land-cover map. The 2017 land-cover map was used in the computation of recharge for all three water-budget simulation scenarios.

\section{Impervious Surfaces}

Impervious surfaces include paved surfaces and buildings. Excess water from the impervious fraction of a subarea $\left(W_{i}\right)$ that is distributed to the pervious fraction of the subarea depends on the impervious fraction of the subarea $(z)$. The impervious fraction of each subarea was computed from a map of impervious surfaces on Maui (National Oceanic and Atmospheric Administration, 2015). Subareas with a water body, reservoir, or taro land-cover classification were assigned a value of zero for impervious fraction. All remaining subareas were reassigned a value of 0.99 for impervious fraction whenever the value computed from the map of impervious surfaces exceeded 0.99. A maximum value of 0.99 was used for these subareas because the model calculations require that excess water from the impervious fraction be distributed to a pervious part of the subarea.

\section{Rainfall}

\section{Present-Day Monthly Rainfall}

The spatial and temporal distributions of rainfall in waterbudget calculations of the 1978-2007 present-day scenario were defined using grid maps of rainfall for the 360 months during 1978-2007. These maps are a subset of the 1,116 maps of rainfall for each month during 1920-2012 for the Hawaiian Islands that
Frazier and others (2016) generated from the Rainfall Atlas of Hawai'i (Giambelluca and others, 2013). Monthly rainfall for each subarea was computed in the model as the product of the monthly rainfall value from Frazier and others (2016) and a mean monthly adjustment factor. Adjustment factors were used because cellby-cell comparisons between mean monthly rainfall calculated for 1978-2007 from the Frazier and others (2016) dataset and the mean monthly values in Giambelluca and others (2013) showed small differences. Each rainfall grid cell was assigned a set of 12 mean monthly adjustment factors, which ensured that mean monthly rainfall estimates of the water-budget model for the 1978-2007 present-day scenario were consistent with those of Giambelluca and others (2013). The mean monthly rainfall adjustment factors for each subarea were determined from the following equation:

$$
\tau(i)=\frac{\bar{P}_{\text {Atlas }}(i)}{\bar{P}_{1978-2007}(i)}
$$

where

$$
\begin{array}{rc}
\tau(i) & \text { is mean monthly rainfall adjustment factor for } \\
& \text { month [dimensionless], } \\
\bar{P}_{\text {Atlas }}(i) & \text { is mean rainfall for month } i \text { during 1978-2007 } \\
& \text { from Giambelluca and others } \\
& \text { (2013) [inches], } \\
\bar{P}_{1978-2007}(i) & \text { is mean rainfall for month } i \text { during 1978-2007 } \\
& \text { from Frazier and others (2016) [inches], } \\
& \text { and } \\
\text { (i) } \quad \begin{array}{l}
\text { is variable designating month in a calendar } \\
\\
\end{array} & \text { year and ranging from a value of 1 to 12. }
\end{array}
$$

The mean monthly rainfall adjustment factors, $\tau(i)$ were applied to the monthly rainfall maps during 1978-2007. The maps of adjusted monthly rainfall were used as the rainfall dataset for the 1978-2007 present-day scenario.

\section{Future Monthly Rainfall}

The availability of high-resolution downscaled climate data, such as the output data from regional climate models (RCMs), enables the direct application of these climate data for hydrologic impact studies at the regional and watershed scale. However, systematic biases are often evident in RCM data when comparing simulated meteorological variables with observations of the present-day climate and these biases can affect the output of hydrologic models (Graham and others, 2007; van Roosmalen and others, 2010; 2011). Hence, bias correction is recommended before using RCM data in hydrologic models (Wilby and others, 2000). A common bias-correction approach is the change-factor method (Hay and others, 2000), which is done by perturbing a present-day climate series with relative change factors derived from the comparison of RCM data from a simulated present-day climate and a projected future climate (van Roosmalen and others, $2007 ; 2009 ; 2010 ; 2011)$. The main underlying assumptions of the change-factor method are that (1) the biases for the presentday and future climate simulations are equal, and (2) the RCMs simulate relative changes better than absolute values. 
In this study, the change-factor method was used to develop datasets of future monthly rainfall by adjusting datasets of presentday monthly rainfall (Frazier and others, 2016) with relative change factors. Two sets of change factors for monthly rainfall were prepared; one set for each of the selected future scenarios. The first set of change factors was calculated from the wet- and dry-season rainfall anomalies of the SD RCP8.5 2071-99 scenario (Elison Timm and others, 2015). The second set of change factors was calculated from the differences in monthly rainfall means between the HRCM 1990-2009 simulation and the HRCM A1B 2080-99 scenario (Zhang and others, 2016a; 2016b). The wet- and dry-season rainfall anomalies of the SD RCP8.5 2071-99 scenario (Elison Timm and others, 2015) were developed relative to mean wet- and dry-season rainfall during 1978-2007 (Giambelluca and others, 2013). However, the climate projections of the HRCM A1B 2080-99 scenario (Zhang and others, 2016b) were developed relative to simulated climate conditions during 1990-2009 (Zhang and others, 2016a). To establish a common reference period among different water-budget model scenarios, the 1978-2007 reference period was selected to develop change factors for the SD RCP8.5 2071-99 and HRCM A1B 2080-99 scenarios. The two sets of change factors were then used to adjust monthly rainfall during 1978-2007 to produce two future scenario rainfall datasets for the water-budget model simulations.

The monthly rainfall input for each subarea of the future scenarios was determined from the equation:

$$
P_{\delta}(i, j)=F_{p}(i) \times P_{1978-2007}(i, j) \times \tau(i)
$$

where

$$
\begin{aligned}
& P_{\delta}(i, j) \quad \text { is rainfall input for month } i \text { and year } j \text { in the } \\
& \text { future scenario [inches], } \\
& F_{p}(i) \quad \text { is relative change factor for month } i \text { in a } \\
& \text { calendar year [dimensionless], } \\
& P_{1978-2007}(i, j) \quad \text { is gridded monthly rainfall for month } i \text { and } \\
& \text { year } j \text { during 1978-2007 from Frazier and } \\
& \text { others (2016) [inches], } \\
& j \quad \text { is variable used to denote year counter that } \\
& \text { ranges from } 1 \text { to } 30 \text { in the present-day and } \\
& \text { future scenarios. }
\end{aligned}
$$

For the SD RCP8.5 2071-99 scenario, the relative change factor, $F_{p}(i)$, for rainfall at each subarea was calculated as follows:

$$
F_{p}(i)=\left(1+A_{\mathrm{RCP} 8.5}\right)
$$

where

$$
\begin{aligned}
& A_{\mathrm{RCP} 8.5} \quad \text { is wet (November to April) or dry (May to } \\
& \text { October) season rainfall anomaly for the } \\
& \text { SD RCP8.5 2071-99 scenario (Elison } \\
& \text { Timm and others, 2015), expressed } \\
& \text { as a fraction of the 1978-2007 mean } \\
& \text { [dimensionless]. }
\end{aligned}
$$

For the HRCM A1B 2080-99 scenario, the relative change factor, $F_{p}(i)$, for rainfall at each subarea was calculated as follows:

$$
F_{p}(i)=\left(1+A_{\mathrm{AlB}}(i)\right)
$$

where

$$
\begin{aligned}
& A_{\mathrm{AlB}}(i) \quad \begin{array}{l}
\text { is rainfall anomaly for month } i \text { determined } \\
\text { from the HRCM 1990-2009 simulation and } \\
\text { HRCM A1B 2080-99 scenario (Zhang and } \\
\text { others, 2016a; 2016b), expressed as a fraction } \\
\text { of the 1978-2007 mean [dimensionless]. }
\end{array}
\end{aligned}
$$

The rainfall anomaly for month $i, A_{\mathrm{AlB}}(i)$, at each subarea was calculated as follows:

$$
A_{\mathrm{AlB}}(i)=\frac{\left(\left(1+\delta_{\mathrm{AlB}}(i)\right) \times \bar{P}_{1990-2009}(i)\right)-\bar{P}_{1978-2007}(i)}{\bar{P}_{1978-2007}(i)}
$$

where

$$
\begin{array}{cc}
\delta_{\mathrm{AlB}}(i) \quad \text { is mean rainfall anomaly for month } i \text { for the } \\
\\
\text { HRCM A1B 2080-99 scenario, expressed as a } \\
\text { fraction of the mean rainfall from the HRCM } \\
\text { 1990-2009 simulation [dimensionless], } \\
\bar{P}_{1990-2009}(i) \quad \begin{array}{l}
\text { is mean rainfall for month } i \text { during 1990-2009 } \\
\text { from Frazier and others (2016) [inches] }
\end{array}
\end{array}
$$

The mean rainfall anomaly for month $i, \delta_{\mathrm{AlB}}(i)$, was computed as follows:

$$
\delta_{\mathrm{AlB}}(i)=\left(\frac{\bar{P}_{f u t}(i)-\bar{P}_{p r e}(i)}{\bar{P}_{p r e}(i)}\right)
$$

where

$$
\begin{gathered}
\bar{P}_{f u t}(i) \quad \text { is mean rainfall for month } i \text { during the HRCM } \\
\text { A1B 2080-99 scenario from Zhang and } \\
\text { others (2016b) [inches], } \\
\bar{P}_{p r e}(i) \quad \text { is mean rainfall for month } i \text { during the HRCM } \\
\text { 1990-2009 simulation from Zhang and } \\
\text { others (2016a) [inches]. }
\end{gathered}
$$

\section{Present-Day Daily Rainfall}

Estimates of the actual rainfall pattern on Maui for each day during the 1978-2007 present-day scenario were not available and were not developed as part of this study. Although records of daily rainfall measurements at gages were available, reconstructing the actual daily rainfall pattern was not attempted because (1) records for many gages have considerable gaps, (2) the spatial interpolation of daily records for gages would have high uncertainty, and (3) the monthly rainfall maps of Frazier and others (2016) were considered to be the best dataset available for estimating historical rainfall patterns. 
The water-budget model of the 1978-2007 present-day scenario synthesized daily rainfall by disaggregating the monthly values of the 1978-2007 rainfall distribution maps using the method of fragments (for example, Oki, 2002). The method of fragments creates a synthetic sequence of daily rainfall from monthly rainfall by superimposing the daily rainfall pattern from a rain gage onto the monthly values of the 1978-2007 rainfall maps. The synthesized daily rainfall data approximate the long-term average character of daily rainfall, such as frequency, duration, and intensity, but may not reproduce the historical daily rainfall record during 1978-2007.

Daily rainfall measurements at 52 rain gages on Maui during 1905-2011 were used to disaggregate monthly rainfall into daily rainfall for the water-budget model. Rain gages were selected on the basis of location and length and completeness of daily records. Daily rainfall data for the rain gages' period of record were obtained from the National Climatic Data Center (www.ncdc. noaa.gov) and the USGS (http://waterdata.usgs.gov/hi/nwis/nwis). Thiessen polygons were drawn around each of the rain gages, and the daily rainfall pattern within each Thiessen polygon was assumed to be the same as the pattern at the rain gage within the Thiessen polygon (fig. 3).

For each rain gage, daily rainfall fragments were computed by dividing each daily rainfall value during a particular month by the total rainfall measured at the gage for that month. This resulted in a set of fragments for that particular month in which the total number of fragments was equal to the number of days in the month. Fragment sets were compiled for every gage for every month in which complete daily rainfall measurements were available. Fragment sets were grouped by month of the year and by rain gage. In the water-budget calculation, the fragment set used for a given gage for a given month (for example, March 1985) was selected randomly from among the sets of fragments for that month of the calendar year (for example, March). Daily rainfall for a given month was synthesized by multiplying total rainfall for that month (from the monthly rainfall maps) by each fragment in the set. Because of insufficient daily records, fragment sets for each of the 12 calendar months were not available for rain gages with Cooperative Station Network numbers 0790, 6635, 6645 , and 7066 . These four gages were assigned fragment sets from nearby gages with similar amounts of mean rainfall. Gage 0790 was assigned the gage 1892 fragment sets, gage 6635 the gage 4887 fragment sets, gage 6645 the gage 9315 fragment sets, and gage 7066 the gage 5404 fragment sets. The resulting daily rainfall fragment dataset was used in the water-budget model simulations for the 1978-2007 present-day scenario.

A separate dataset of daily rainfall fragments was developed for Maui using the distributions of simulated daily rainfall produced by the HRCM 1990-2009 simulation (Zhang and others, 2016a). For each 1-km grid cell in the HRCM, daily rainfall fragments were computed by dividing each simulated daily rainfall value for a particular month by the total rainfall simulated at the grid cell for that month. Fragment sets were then grouped by month of the year and by grid cell. The 20 -year HRCM simulation period produced a total of 240 fragment sets for each grid cell (that is, 20 fragment sets for each calendar month), except for grid cells where the HRCM simulations resulted in no rainfall over an entire calendar month. In these cases, the number of fragment sets at a particular grid cell was reduced by the number of months in the HRCM simulation with no rainfall. The daily rainfall pattern for all model subareas within each HRCM grid cell was assumed to be the same. The dataset of simulated daily rainfall fragments from the HRCM 1990-2009 simulation and the dataset of daily rainfall fragments for the 1978-2007 present-day scenario represents different reference conditions in terms of daily rainfall frequency and could have dissimilar impacts on estimated recharge using the water-budget model. Hence, only the daily rainfall fragment dataset for the 1978-2007 present-day period was used in the water-budget-model simulations for the presentday scenario to enable direct comparisons of model results to a common reference climate condition. However, the daily rainfall fragment dataset for the HRCM 1990-2009 simulation was used to assess the effects of potential changes in the daily rainfall frequency on estimated recharge for the HRCM A1B 2080-99 scenario (see Assessing the Effects of Selected Climate Inputs on Estimated Recharge section).

\section{Future Daily Rainfall}

The rainfall projections for the RCP family of warming scenarios (Elison Timm and others, 2015) do not describe projected changes in daily rainfall frequency, magnitude, or duration. In a separate analysis for CMIP3 A1B and A2 emission scenarios, Timm and others (2011) projected small changes in the number of late-21st century heavy rainfall days using a statistical downscaling approach. However, their projections have large uncertainties resulting from disparities among the climate models for $\mathrm{A} 1 \mathrm{~B}$ and $\mathrm{A} 2$ emission scenarios. Because of the lack of information on projected changes in daily rainfall for the SD RCP8.5 2071-99 scenario, a separate dataset of rainfall fragments for this particular scenario was not developed. A separate dataset of daily rainfall fragments was developed for the HRCM A1B 2080-99 scenario using the distributions of simulated daily rainfall produced by the HRCM (Zhang and others, 2016b). However, to enable direct comparisons among the results from the three water-budgetmodel scenarios, the daily rainfall fragments developed for the 1978-2007 present-day scenario also were used in the water-budget simulations for the SD RCP8.5 2071-99 and HRCM A1B 2080-99 scenarios. The datasets of daily rainfall fragments developed from simulated daily rainfall distributions produced by the HRCM were used to assess the effects of potential changes in daily rainfall frequency on estimated recharge (see Assessing the Effects of Selected Climate Inputs on Estimated Recharge section).

\section{Fog Interception}

In Hawai' $i$, clouds can form when a moist air mass cools and condenses as it is forced upslope by trade winds or by thermal circulation systems such as sea breezes. As clouds 
flow near the land surface, some of the cloud moisture may accumulate on vegetation through a process called cloudwater interception or fog interception. At places where fog interception is frequent, intercepted cloud moisture that reaches the ground can be a substantial part of the water budget (Ekern, 1964; Juvik and Ekern, 1978; Juvik and Nullet, 1995; Heath and Huebert, 1999; Scholl and others, 2007; Giambelluca and others, 2011; Takahashi and others, 2011). The cloud zone includes areas that frequently have clouds and is between altitudes of about 2,000 and 8,200 ft in Hawai'i (fig. 4; DeLay and Giambelluca, 2010). However, clouds can also form in areas above the cloud zone (Juvik and Ekern, 1978).

Fog interception was quantified in the water-budget model for four land-cover classes: (1) alien forest, fog, (2) native forest, fog, (3) tree plantation, fog and (4) shrubland for subareas above the base of the cloud zone. On the basis of previous fog and cloud-water interception estimates for Hawai ' $i$, mean annual fog interception for forests on Maui was assumed to vary with altitude and aspect for the water budget (see table 3 in Johnson and others, 2018). Mean annual fog interception was assumed to decrease uniformly with altitude from the values for the cloud zone to 6 inches per year (in/yr) near the Haleakalā summit. A complete description of the development of these fog interception rates for use in the water-budget model is provided in Johnson and others (2018).

Mean annual fog-interception rates for shrubland subareas were assumed to be half of the rates for forest subareas (see table 3 in Johnson and others, 2018). Fog interception was assumed to be negligible at all altitudes for land-cover classes other than forests (alien forest, fog; native forest, fog; and tree plantation, fog) and shrubland. Coffee and macadamia land cover types, which have the potential to intercept fog moisture, were assumed to have no fog interception for this study because they are at altitudes below the cloud zone (fig. 4).

Because of the sparseness of monthly fog data for Maui, mean annual fog interception for a given subarea was apportioned equally to each month of the year in the water-budget calculations for the 1978-2007 present-day scenario. Fog interception was assumed to occur only on days with rainfall. Daily fog interception was computed in the water budget as a fraction of daily rainfall equivalent to the ratio of mean monthly fog interception and mean monthly rainfall during 1978-2007. These resulting fog-to-rainfall ratios were used to compute recharge for the 1978-2007 presentday scenario. Potential changes in fog-interception rates were not quantified in the downscaled climate projection datasets of the SD RCP8.5 2071-99 and HRCM A1B 2080-99 scenarios (Elison Timm and others, 2015; Zhang and others, 2016a; 2016b; Elison Timm, 2017). Because of the lack of information on potential changes to fog-interception rates in future-climate scenario datasets, the same fog-to-rainfall ratios were used to compute recharge for each of the future-climate scenarios.

The HRCM simulations for a HRCM A1B 2080-99 scenario indicate that the mean annual cloud-base height, cloud-top height, and base height of the trade-wind inversion are projected to decline slightly across Maui (Zhang and others, 2016b). The projected decline in the cloud-base height across Maui ranges from
10 to $15 \mathrm{~m}$ (33 to $49 \mathrm{ft}$ ), and the projected decline in the cloudtop height ranges from 0 to $25 \mathrm{~m}$ ( 0 to $82 \mathrm{ft}$ ). These results imply that the projected changes to the effective thickness of the cloud zone are not uniform across Maui and may range from increases of as much as $15 \mathrm{~m}(49 \mathrm{ft})$ in some areas to decreases of as much as $15 \mathrm{~m}(49 \mathrm{ft})$ in other areas. The effect of these small nonuniform changes in the cloud-base and cloud-zone heights was not considered in this study. Hence, the altitude ranges described in table 3 of Johnson and others (2018) were used for each of the three water-budget simulation scenarios.

\section{Irrigation}

Irrigation rates were estimated in the model only for subareas that were classified as agriculture (coffee, diversified agriculture, pineapple, seed corn, and taro) or other land-cover classes (golf course, high-intensity developed, and medium-intensity developed) that were assumed to contain irrigated lawns and landscapes. No irrigation was applied for the macadamia landcover class in the model scenarios, similar to the approach used in previous model analyses of Maui (Engott and Vana, 2007; Johnson and others, 2018). Two methods were used to estimate irrigation rates in the model: a constant-value method was used for subareas with taro, and a demand-based method was used for all remaining subareas of an irrigated land-cover class. The approach described herein was used to estimate irrigation rates for each of the presentday and future-climate scenarios.

All subareas of the taro land-cover class were assigned a constant recharge rate of $455 \mathrm{in} / \mathrm{yr}$ in the model on the basis of water-use studies for various taro pond fields in Hawai' $\mathrm{i}$ (Miles, 1931; Watson, 1964; De la Pena and Melchor, 1984; Berg and others, 1997), although local differences in recharge rate likely exist. For this study, taro was assumed to be grown in flooded pond fields that were continually saturated. The constant recharge rate of $455 \mathrm{in} / \mathrm{yr}$ was also used for subareas of the taro land-cover class in other water-budget analyses of the islands of Kaua' $\mathrm{i}$, Maui, and O'ahu (Engott and others, 2017; Izuka and others, 2018; Johnson and others, 2018). In the model calculations, the constant recharge rate of $455 \mathrm{in} / \mathrm{yr}$ from subareas of the taro land-cover class was treated as direct recharge and allocated in equal amounts, about 1.25 inches per day, to each day of a year. For all remaining irrigated landcover classes, monthly irrigation rates were computed using equation 16 in Johnson and others (2018).

Irrigation-method efficiency is the fraction of applied irrigation water that becomes available for plant consumption. Seed corn, diversified agriculture, and pineapple were assumed to use drip irrigation, which has an irrigation-method efficiency of 0.85 (University of Hawai' $i$, 2008). Coffee was assumed to use micro-spray irrigation, which has an irrigation efficiency of 0.80 . Golf course, and medium- and high-intensity developed landcover classes were assumed to use sprinkler irrigation, which has an irrigation efficiency of 0.70 .

For all irrigated land-cover classes other than pineapple and taro, monthly irrigation estimated from equation 16 in Johnson and others (2018) was allocated in equal amounts for 
each day of a given month. Similar to the approach taken in Engott and Vana (2007) for pineapple irrigation, the monthly irrigation volume calculated for pineapple using equation 16 in Johnson and others (2018) was uniformly distributed on days $1,2,3,8,9,10,15,16,17,22,23,24$, and 28 of each month. Simulation of the pineapple cultivation cycle was not represented in this study and irrigation was assumed for all months of the simulation period. Seed corn irrigation for this study is based on a cultivation cycle of two crops per year. Only 25 percent of subareas classified as seed corn are cultivated at any one time, leaving the remaining 75 percent of subareas to be classified as fallow/grassland. This approach was developed on the basis of cultivation practices on Moloka' $i$ and used by Engott and others (2017) for estimating corn irrigation.

The model's irrigation estimates for diversified agriculture and medium- and high-intensity land-cover types were adjusted with irrigation-adjustment factors. These factors ensured that the model's irrigation estimates were, on average, consistent with reported rates of irrigation and rates of water available for irrigation. The irrigation-adjustment factors developed by Johnson and others (2018) for diversified agriculture, 0.41 , and medium- and high-intensity developed land-cover types, 0.37 , also were used for all model scenarios in this study. The estimated irrigation rates for coffee, golf course, pineapple, and seed corn were not adjusted.

\section{Septic Effluent}

Septic effluent for this study consisted of cesspool seepage and septic-system leachate. In the model calculations, cesspool seepage was counted as direct recharge, whereas septic-system leachate was added to the plant-root zone where it was subject to evapotranspiration. Some buildings and premises on Maui use onsite disposal systems (OSDS) to dispose of wastewater. Whittier and El-Kadi (2013) compiled an inventory of OSDS on Maui. For each tax map key (TMK) parcel, Whittier and El-Kadi (2013) specify the number and type (class) of OSDS and the total estimated septic effluent flux for each type of OSDS. Each TMK parcel may contain one or more model subareas. Hence, all subareas, including those not in the developed land-cover class, within a TMK parcel that contain an OSDS can have septic effluent. For TMK parcels with cesspools, the total estimated septic effluent flux was transformed into an equivalent depth per unit time by dividing the flux by the parcel area, hereinafter the cesspool seepage rate. For subareas within TMK parcels with cesspools, the cesspool seepage rate was applied as direct recharge (see Direct Recharge section). For TMK parcels with other types of OSDS, the effluent flux was transformed into equivalent depth per unit time, hereinafter the septic-system leachate rate. For subareas within TMK parcels with other types of OSDS, the septic-system leachate rate applied only to the pervious fraction. However, the septic-system leachate rate in each subarea was adjusted by dividing the rate by the pervious fraction. The adjustment to the septic-system leachate rate was needed to maintain the same volumetric rate of discharge within each subarea. In the model calculations, the adjusted septic-system leachate rate was added to the plant-root zone of the subarea. For this study, no changes in cesspool seepage and septic-system leachate rates, and no changes in the pervious fraction of each subarea were assumed for the present-day and future-climate scenarios.

\section{Storm-Drain Systems}

Some developed areas on Maui have storm-drain systems that collect and divert stormwater runoff. Water collected by storm-drain systems may be diverted into streams, gulches, the ocean, infiltration basins, and drywells. In the model calculations, water collected by storm-drain systems was added to either recharge or direct runoff, depending on location. For this study, the approach developed by Johnson and others (2018) was used to account for water collected and disposed by storm-drain systems for each of the presentday and future-climate scenarios. In the water-budget calculation, only subareas with medium- and high-intensity developed land-cover classes were assumed to have stormdrain systems (fig. 4). For these subareas, excess water that flows off impervious surfaces was assumed to be collected by storm-drain systems instead of flowing to adjacent pervious surfaces. For subareas within the 'Īao, Kahului, Pā'ia, and Kama'ole aquifer-system boundaries (fig. 1), excess water collected by storm-drain systems was added to direct runoff because it was assumed to be diverted into streams, gulches, and the ocean. For subareas within the Honokōwai, Honolua, and Launiupoko aquifer-system boundaries (fig. 1), excess water collected by storm-drain systems was halved into direct runoff and recharge because it was assumed to be diverted into streams and gulches as well as infiltration basins and dry wells. All other subareas with storm drains in the remaining aquifer systems on Maui were assumed to have systems that divert excess water into infiltration basins or drywells. Excess water collected by these systems was added to recharge. Exceptions to the general approach likely exist but would require additional investigation to identify and this was beyond the scope of the study.

\section{Direct Runoff}

Direct runoff, hereinafter runoff, is a fraction of rainfall that does not contribute to net moisture gain within the plantroot zone. For this study, the approach by Johnson and others (2018) was modified for use in the water-budget simulations for each of the present-day and future-climate scenarios. For each model subarea, daily runoff was computed in the model as the product of daily rainfall and a seasonal runoff-to-rainfall ratio, $r r_{t, j}$, where $t$ represents the season (wet or dry) and $j$ represents the year of interest. November through April was considered the wet season, and May through October was considered the dry season. The seasonal $r r_{t, j}$ values used to compute runoff were either observed or were estimated using 
an empirical equation as described below. Observed seasonal $r r_{t, j}$ values were determined for gaged drainage basins where complete six-month rainfall and streamflow data pairs were available. Eight drainage basins on Maui had sufficient rainfall and streamflow data for estimating observed seasonal $r r_{t, j}$ values during the 1978-2007 present-day scenario (table 3).

To account for the interannual variability in rainfall-runoff relations during each of the present-day and future-climate scenarios, an empirical equation was developed for this study to compute estimated seasonal $r r_{t, j}$ values by modifying estimated mean seasonal $\overline{r r} r_{t}$ values for periods (or basins) when (or where) observed seasonal $r r_{t, j}$ values were not available. The empirical equation computes estimated seasonal $r r_{t, j}$ values using inputs of mean seasonal $\overline{r r}$ values, mean seasonal rainfall $\bar{r} f_{t}$, and seasonal rainfall $r f_{t, j}$, as described below. For gaged basins, the mean seasonal $\overline{r r_{t}}$ values were computed for average climate conditions during 1978-2007 or a similar representative period. For ungaged basins, the mean seasonal $\overline{r r}_{t}$ values were estimated using a regional-regression analysis that considered 30 different basin characteristics including soil, climate, land-cover, and morphometric characteristics (see table 5 in Johnson and others, 2018).

\section{Computation of Seasonal Runoff-to-Rainfall Ratios}

A set of 488 catchment zones delineated by Rea and Skinner (2012) for Maui were used in the water-budget simulation to estimate runoff (fig. 6). Seasonal $r r_{t, j}$ values were computed for each catchment zone for each of the 30 wet and 30 dry seasons during the 1978-2007 present-day scenario. Similarly, a separate set of seasonal $r r_{t, j}$ values were computed for each catchment zone during the 30 -year simulation periods for each of the two future scenarios. The boundaries of the catchment zones were incorporated into the polygon map of model subareas used in the water-budget simulation. Hence, the seasonal $r r_{t, j}$ values assigned to a given catchment zone also were assigned to each subarea within the given catchment zone. For the purposes of computing and assigning seasonal $r r_{t, j}$ values, each catchment zone was classified as either gaged or ungaged and as either windward or leeward (fig. 6). Gaged catchment zones were those with boundaries that were within one of the eight gaged drainage basins identified as having sufficient rainfall and streamflow data for computing observed seasonal $r r_{t, j}$ values (fig. 6). All remaining catchment zones were considered ungaged. The delineation of boundaries between windward and leeward regions on Maui for use in the water-budget model analyses is described by Johnson and others (2018).

\section{Observed Seasonal Runoff-to-Rainfall Ratios}

Observed seasonal $r r_{t, j}$ values were computed for the eight gaged drainage basins identified as having sufficient rainfall and streamflow data during the 1978-2007 presentday scenario (table 3). Each observed seasonal $r r_{t, j}$ value for a gaged drainage basin was computed as the quotient of cumulative runoff and cumulative rainfall within the drainage basin during the season and year of interest. For example, the observed seasonal $r r_{t, j}$ value for the drainage basin of streamgaging station 16552800 for the dry season of 1995 was computed as the quotient of cumulative runoff and cumulative rainfall in its drainage basin during May-October 1995. Cumulative runoff was computed using daily streamflow data recorded at the stream-gaging station and the methods and parameters to separate direct runoff from total streamflow as described in Johnson and others (2018). Cumulative rainfall was estimated using the 1978-2007 monthly rainfall maps (Frazier and others, 2016). The observed seasonal $r r_{t, j}$ values were assigned to the "gaged" catchment zones delineated within each of the eight gaged drainage basins.

Table 3. Periods of records used to compute observed seasonal runoff-to-rainfall ratios for drainage basins of selected stream-gaging stations in the study area on the Island of Maui, Hawai'i, 1978-2007.

[Station localities and drainage basin locations are shown on figure 6]

\begin{tabular}{|c|c|c|c|c|c|}
\hline \multirow{2}{*}{$\begin{array}{l}\text { Gaging- } \\
\text { station } \\
\text { number }\end{array}$} & \multirow[t]{2}{*}{ Stream/ river/ gulch } & \multicolumn{2}{|c|}{$\begin{array}{l}\text { Period of record } \\
\text { used to compute } \\
\text { observed seasonal } \\
\text { runoff-to-rainfall ratios }\end{array}$} & \multicolumn{2}{|c|}{$\begin{array}{c}\text { Number of } \\
\text { observed seasonal } \\
\text { runoff-to-rainfall ratios }\end{array}$} \\
\hline & & Start & End & $\begin{array}{l}\text { Wet season (November } \\
\text { through April) }\end{array}$ & $\begin{array}{l}\text { Dry season (May } \\
\text { through October) }\end{array}$ \\
\hline 16501200 & 'Ohe‘o Gulch & 1989 & 2007 & 14 & 13 \\
\hline 16508000 & Hanawī Stream & 1978 & 2007 & 30 & 30 \\
\hline 16518000 & West Wailuaiki Stream & 1978 & 2007 & 30 & 30 \\
\hline 16587000 & Honopou Stream & 1978 & 2007 & 30 & 30 \\
\hline 16604500 & Wailuku River & 1984 & 2007 & 21 & 22 \\
\hline 16614000 & Waihe'e River & 1984 & 2007 & 23 & 24 \\
\hline 16618000 & Kahakuloa Stream & 1978 & 2007 & 30 & 30 \\
\hline 16620000 & Honokōhau Stream & 1978 & 2007 & 28 & 27 \\
\hline
\end{tabular}




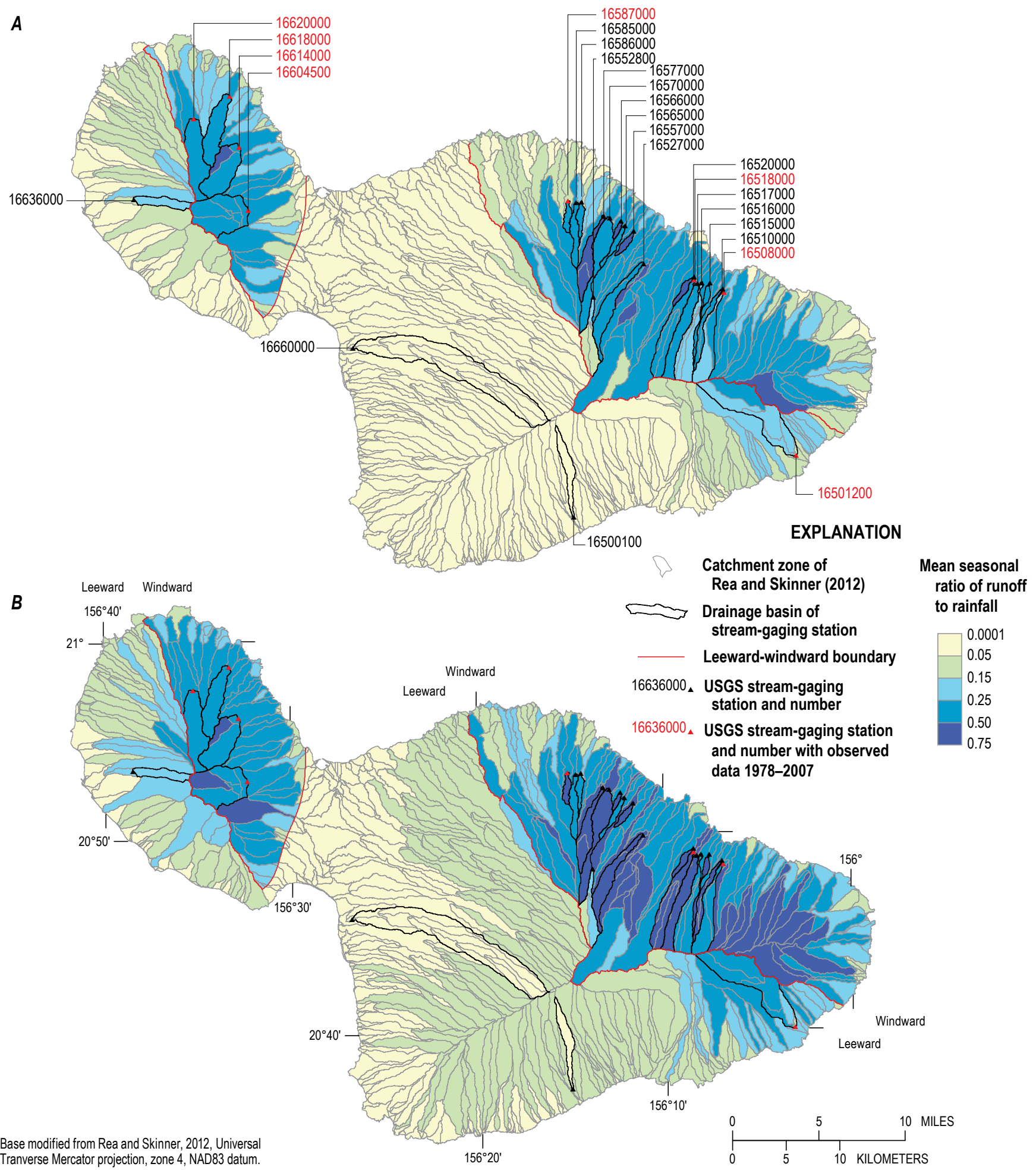

Figure 6. Maps of mean seasonal runoff-to-rainfall ratios for the $(A)$ Dry-season months: May through October and $(B)$ Wet-season months: November through April for drainage basins of selected stream-gaging stations and catchment zones on the Island of Maui, Hawaili (modified from Johnson and others, 2018). 
Of the eight stream-gaging stations that had sufficient monthly data, three had drainage basins composed of a single catchment zone and five had drainage basins composed of multiple catchment zones. Observed seasonal $r r_{t, j}$ values computed for each of the drainage basins of three streamgaging stations (16587000, 16618000, and 16620000) were assigned to the single-catchment zone within each of these drainage basins (fig. 6). Observed seasonal $r r_{t, j}$ values computed for each of the drainage basins of the remaining five stream-gaging stations (16501200, 16508000, 16518000, 16604500 , and 16614000) were spatially disaggregated, using equation 17 in Johnson and others (2018), and then assigned to the multiple catchment zones within each gaged drainage basin.

\section{Mean Seasonal Runoff-to-Rainfall Ratios}

Observed mean seasonal $\overline{r r_{t}}$ values of 25 gaged drainage basins on Maui (fig. 6) with rainfall and runoff conditions generally representative of those during 1978-2007 are presented in table 4 of Johnson and others (2018). The criteria for selecting periods of record to compute observed mean seasonal $\overline{r r}$ values are described in Johnson and others (2018). Each observed mean seasonal $\overline{r r_{t}}$ value for each gaged drainage basin was computed as the quotient of cumulative direct runoff and cumulative rainfall during the appropriate season of the selected period. Thirteen of the 25 gaged drainage basins contain a single catchment zone. The observed mean seasonal $\overline{r r_{t}}$ values were assigned to the single "gaged" catchment zone delineated within each of these 13 gaged drainage basins. The remaining 12 gaged drainage basins contain multiple catchment zones. Observed mean seasonal $\overline{r r}$ values computed for each of these 12 drainage basins were spatially disaggregated, using equation 17 in Johnson and others (2018), and then assigned to the multiple catchment zones within each gaged drainage basin. For ungaged catchment zones, estimated mean seasonal $\overline{r r_{t}}$ values were computed using regional-regression equations presented in table 5 of Johnson and others (2018). The mean seasonal $\overline{r r_{t}}$ values were used to compute estimated seasonal $r r_{t, j}$ values in all catchment zones when observed seasonal $r r_{t, j}$ values were not available.

\section{Estimated Seasonal Runoff-to-Rainfall Ratios}

Regression analyses were conducted to develop an equation for computing estimated seasonal $r r_{t, j}$ values (equation 7). The regression analyses were done to account for the interannual variability in rainfall-runoff relations compared to the mean during the water-budget model simulation period. Equation 7 was used to compute estimated seasonal $r r_{t, j}$ values for all catchment zones when observed seasonal $r r_{t, j}$ values were not available (gaged basins during periods without observations and ungaged basins during all periods) for each present-day scenario, and for all catchment zones for each future-climate scenario:

$$
\begin{gathered}
r r_{t, j}=\overline{r r} \times\left((s-c) \times\left(1-\exp \left(-\frac{r f_{t, j} / \bar{r} f_{t}}{a}\right)\right)+c\right) \\
\text { for } r r_{t, j} \leq 0 \\
r r_{t, j}=0
\end{gathered}
$$

where

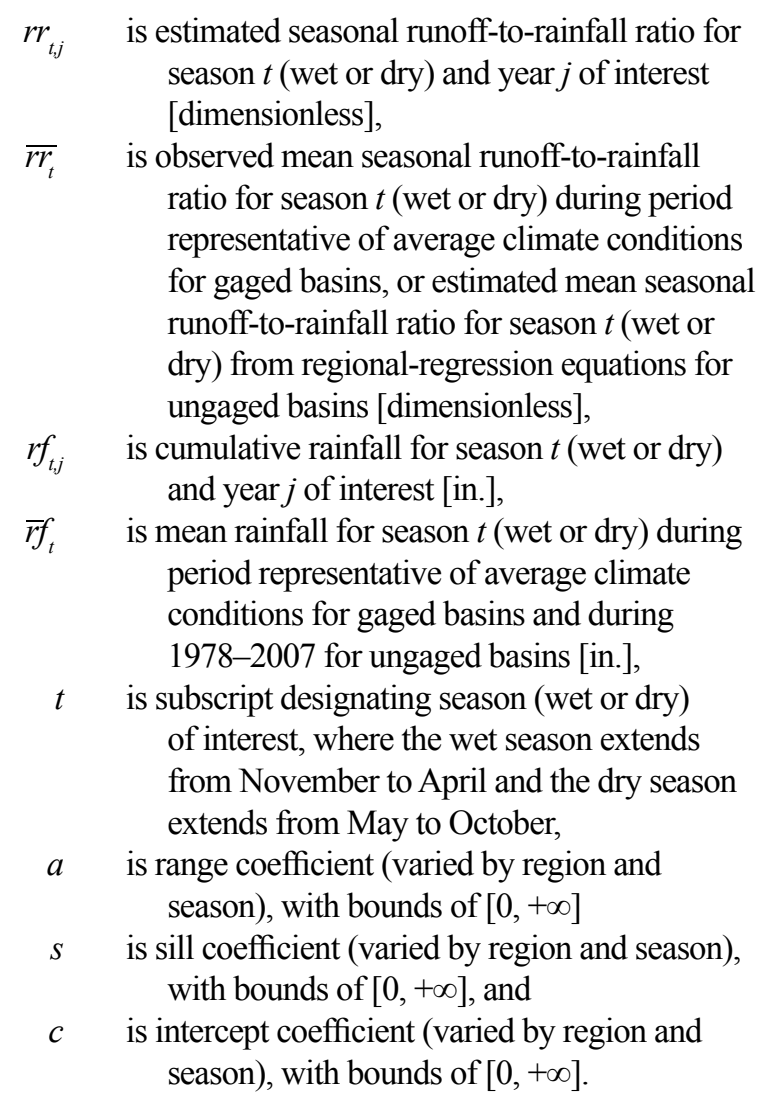

Four sets of range, sill, and intercept coefficients were developed for equation 7 , one for each region (windward and leeward) and season (wet and dry) (table 4). Values assigned to each set of coefficients $(a, s$, and $c$ ) were derived from regression analyses of observed seasonal $r r_{t, j}$, seasonal rainfall $r f_{t, j}$, observed mean seasonal $\overline{r r}$, and mean seasonal $\bar{r} f_{t}$ rainfall values for the drainage basins of 55 selected stream-gaging stations on three islands (Kaua'i, O'ahu, and Maui) and listed in table 4 in Johnson and others (2018). For each of the 55 stations, observed seasonal $r r_{t, j}$ and seasonal rainfall $r f_{t, j}$ values were computed for seasons when the station had streamflow data during 1920-2007. The period 1920-2007 was selected for this analysis to be consistent with the approach used to compute mean seasonal $\overline{r r} t$ values, as described in Johnson and others (2018). Seasonal rainfall $r f_{t, j}$ values were computed using monthly rainfall maps from Frazier and others (2016). Observed mean seasonal $\overline{r r}{ }_{t}$ values for 
each station were obtained from table 4 in Johnson and others (2018), and mean seasonal rainfall $\bar{r} f_{t}$ values were computed for the periods shown in table 4 in Johnson and others (2018) using monthly rainfall maps from Frazier and others (2016). Seasonal rainfall $r f_{t, j}$ and observed seasonal $r r_{t, j}$ values were then normalized by mean seasonal rainfall $\overline{r f}$ and observed mean seasonal $\overline{r r}$ values, respectively. For each region-season pairing, the normalized rainfall ratio $r f_{t, j} / \bar{r} f_{t}$ and seasonal runoff-to-rainfall ratio $r r_{t, j} / \overline{r r}_{t}$ values were binned into a minimum of 23 equally spaced intervals with a minimum of five data pairs per bin, and values for $a, s$, and $c$ were estimated as the least-square fit through the median of each bin (fig. 7).

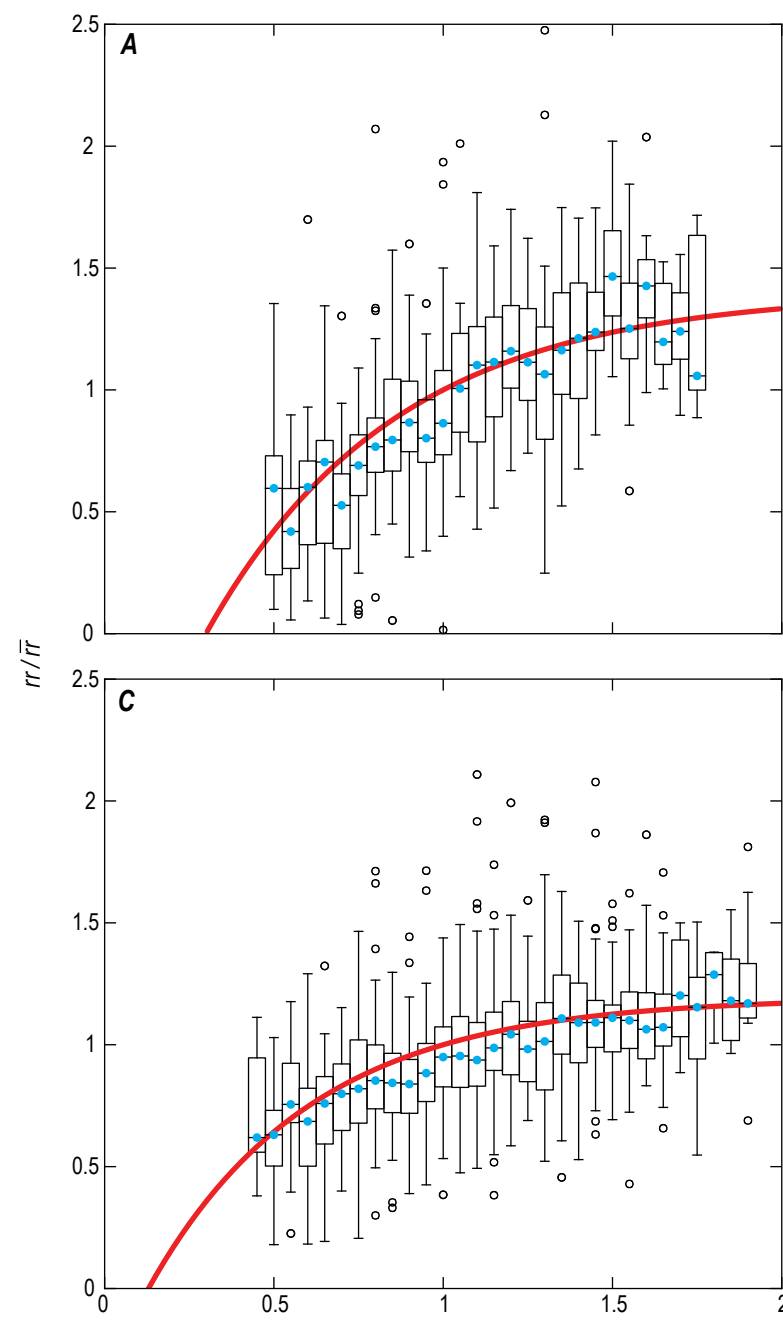

Table 4. Coefficients for equation 7 that were used to estimate seasonal runoff-to-rainfall ratios for catchment zones on the islands of Kaua'i, O’ahu, and Maui, Hawai'i.

[See figure 6 for locations of leeward and windward regions on Maui; Wet season is November through April; Dry season is May through October]

\begin{tabular}{lcccc}
\hline \multirow{2}{*}{ Region } & \multirow{2}{*}{ Season } & \multicolumn{3}{c}{ Coefficient } \\
\cline { 3 - 5 } & & $\boldsymbol{a}$ (range) & $\boldsymbol{s}$ (sill) & $\boldsymbol{c}$ (intercept) \\
\hline Windward & Wet & 0.470 & 1.192 & -0.416 \\
Windward & Dry & 0.695 & 1.444 & -0.427 \\
Leeward & Wet & 0.560 & 1.400 & -0.990 \\
Leeward & Dry & 0.601 & 1.673 & -1.881 \\
\hline
\end{tabular}
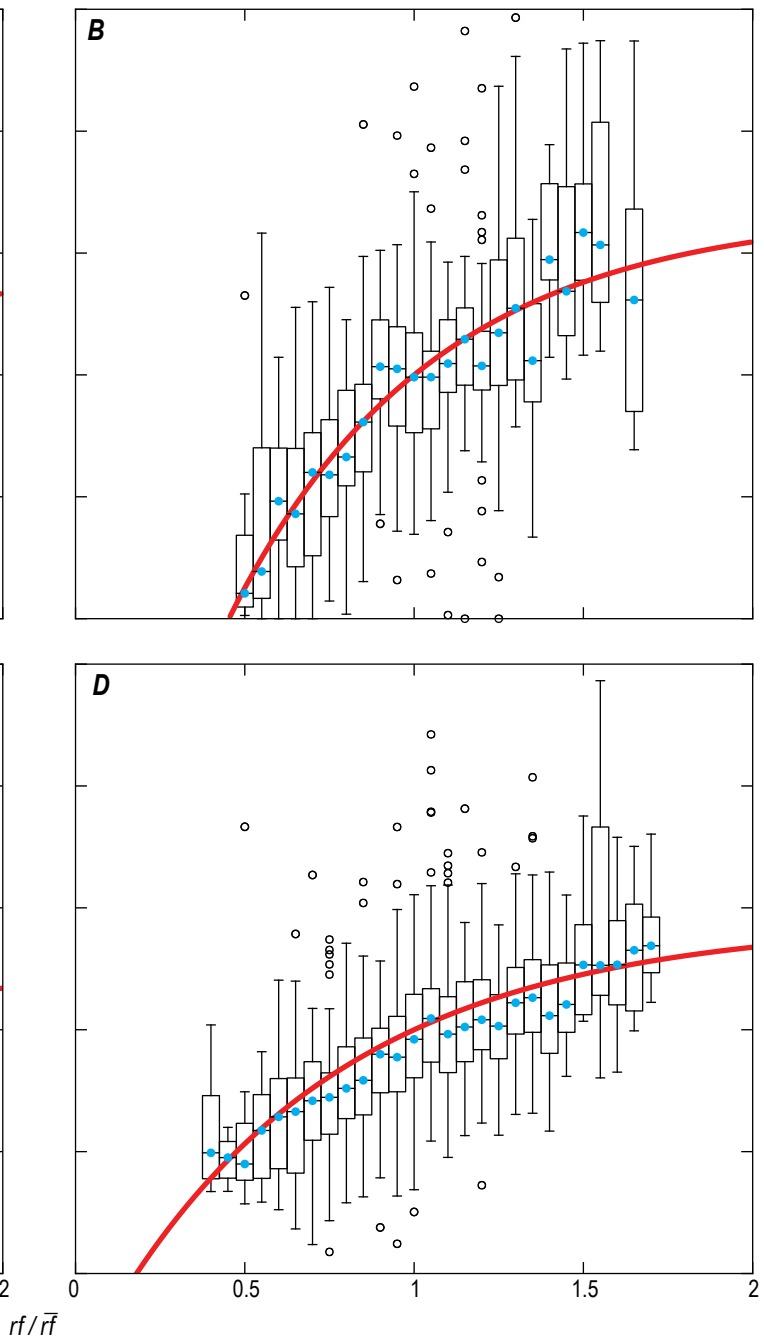

EXPLANATION

$$
\begin{aligned}
& r f-\text { Cumulative seasonal rainfall } \\
& \overline{r f} \text {-Mean seasonal rainfall during period of average } \\
& \quad \text { climate conditions } \\
& r r \text {-Observed seasonal runoff-to-rainfall ratio } \\
& \overline{r r} \text {-Observed mean seasonal runoff-to-rainfall ratio }
\end{aligned}
$$

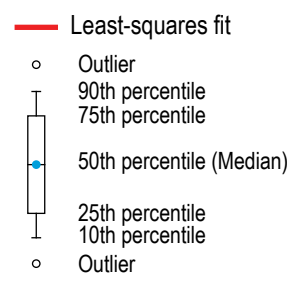

Figure 7. Least-square fit curves of normalized rainfall and seasonal runoff-to-rainfall ratio values derived from 55 drainage basins on the islands of Kaua'i, O'ahu, and Maui. $(A)$ Leeward region and wet season, $(B)$ Leeward region and dry season, $(C)$ Windward region and wet season, and $(D)$ Windward region and dry season. 
A range of regression functions with up to three fitting parameters was tested using a trial-and-error approach. The form of equation 7 was selected because it could be used to satisfy the following set of conditions:

$$
\begin{gathered}
\text { for } r f_{t, j} / \bar{r} f_{t}=1 \\
r r r_{t, j}=\overline{r r}, \\
\text { for } r f_{t, j} / \bar{r} f_{t}>>1, \\
r r_{t, j} \cong s \times \overline{r r},
\end{gathered}
$$

Estimated seasonal $r r_{t, j}$ values were computed for each catchment zone on Maui using equation 7 and the appropriate set of coefficients from table 4 when observed seasonal $r r_{t, j}$ values were not available for the 1978-2007 present-day scenario. Equation 7 was also used to compute estimated seasonal $r r_{t, j}$ values for each catchment zone for the SD RCP8.5 2071-99 and HRCM A1B 2080-99 scenarios. Seasonal rainfall $r f_{t, j}$ values for each present-day scenario were estimated from monthly rainfall maps of Frazier and others (2016). Seasonal rainfall $r f_{t, j}$ values for each future-climate scenario were estimated from the future monthly rainfall maps developed for this study. Mean seasonal rainfall $\bar{r} f_{t}$ values were estimated from the mean monthly rainfall maps of Giambelluca and others (2013). Mean seasonal $\overline{r r}$ values were obtained from table 4 in Johnson and others (2018) or computed using the regional-regression equations in table 5 of Johnson and others (2018), as described earlier.

In summary, the estimated seasonal $r r_{t, j}$ values varied temporally and were (1) greater than mean seasonal $\overline{r r_{t}}$ values for seasons when rainfall was greater than the seasonal average, (2) equal to mean seasonal $\overline{r_{t}}$ values for seasons when rainfall was equal to the seasonal average, and (3) less than mean seasonal $\overline{r r_{t}}$ values for seasons when rainfall was less than the seasonal average.

\section{Evapotranspiration}

Evapotranspiration (ET) is the sum of all water that is evaporated or transpired from a vegetated surface and plantroot zone. Evapotranspiration can be divided into three main evaporative processes (1) canopy evaporation, which is evaporation of intercepted rain and fog from the surface of vegetation; (2) ground evaporation, which is evaporation of water from the soil surface and overlying litter and mulch layers; and (3) transpiration, the process by which soil moisture taken up by vegetation is eventually evaporated through plant pores (Viessman and Lewis, 2003). All three ET processes (canopy evaporation, ground evaporation, and transpiration) are represented in the total-ET estimates of the water-budget model.

For this study, total ET from subareas of the forest landcover class is computed by separately estimating forest-canopy evaporation and combined ground evaporation and transpiration from the plant-root zone. Evaporation from the forest canopy and evapotranspiration from the plant-root zone are added together to yield total ET. For subareas of nonforest land-cover classes, ET is computed using a more traditional approach in which canopy evaporation, ground evaporation, and transpiration are not separately estimated. The concept of potential ET, combined with empirical models when soil moisture is limited, is used to estimate ground evaporation and transpiration in forests and total ET for all other land-cover classes. A similar approach to estimating total ET was used by Johnson and others (2018).

\section{Forest-Canopy Evaporation}

Canopy evaporation, the fraction of precipitation that accumulates on and then evaporates from vegetation, was computed for subareas of the forest land-cover class (native forest, alien forest, and tree plantation) only. The model computes forestcanopy evaporation using equations 4 and 5 in Johnson and others (2018), which were derived from the rainfall-interception model described in Gash and others (1995). These equations require estimates of daily precipitation and the following parameters (1) canopy capacity, (2) trunk-storage capacity, (3) proportion of precipitation diverted to stemflow, (4) canopy cover, and (5) the ratio of the mean evaporation rate to mean precipitation rate during saturated conditions, $V$.

Canopy capacity, trunk-storage capacity, and the proportion of precipitation diverted to stemflow were set to 0.05 inches, 0.01 inches, and 4 percent, respectively, for each subarea with a forest land-cover classification. These values were estimated by Johnson and others (2018) on the basis of published data for Hawai'i (Gaskill, 2004; DeLay, 2005; Takahashi and others, 2011; Safeeq and Fares, 2014). The canopy cover of each subarea with a forest land-cover classification was estimated from a gridded map of mean annual vegetation cover for Maui (Giambelluca and others, 2014). The estimated canopy-cover values for subareas of the forest land-cover class ranged from 0.03 (meaning 3-percent canopy cover) to 1.00 (meaning a dense canopy with no gaps). The area-weighted mean canopy-cover value for subareas of the forest land-cover class ranged from 0.81 for alien forest below the fog zone to 0.96 for tree plantation below the fog zone.

Johnson and others (2018) developed an equation to estimate the spatial distribution of $V$ as follows:

$$
\begin{gathered}
\text { for } w<0.009, \\
V=0.01 \\
\text { for } 0.009 \leq w \leq 0.192, \\
V=2.677 \times(w)-0.014, \text { and } \\
\text { for } w>0.192, \\
V=0.50,
\end{gathered}
$$

where

is mean annual wind speed divided by mean annual rainfall [(meters/second)/inch]. 
The spatial distribution of $V$ estimated by Johnson and others (2018) was used for the 1978-2007 present-day scenario. Values of $V$ ranged from 0.01 to 0.50 , with wetter areas typically having lower values than drier areas. The spatial distribution of $V$ estimated by Johnson and others (2018) was used for the SD RCP8.5 207199 scenario because of a lack of information on potential changes in wind speed. This information is needed to estimate potential changes in $V$. An analysis of the effects of potential changes in the spatial distribution of $V$ for future-climate scenarios on waterbudget results is included in the Assessing the Effects of Selected Climate Inputs on Estimated Recharge section of this report.

For the HRCM A1B 2080-99 scenario, the change-factor approach was used in this study to develop the spatial distribution of $V$ by adjusting the ratio $w$ in equation 9 with relative change factors for mean annual wind speed and mean annual rainfall determined from the HRCM 1990-2009 simulation and the HRCM A1B 2080-99 scenario (Zhang and others, 2016a; 2016b). Relative change factors for mean annual wind speed and mean annual rainfall were calculated from the differences in annual means between the retrospective simulation and future scenario. Mean annual wind speed for the HRCM 1990-2009 simulation and the HRCM A1B 2080-99 scenario was computed using simulated hourly zonal and meridional wind speed at a height of $10 \mathrm{~m}$ (Zhang and others, 2016a; 2016b). The datasets of simulated wind speed for the HRCM 1990-2009 simulation and the HRCM A1B 2080-99 scenarios were provided by the University of Hawai'i at Mānoa (see HRCM data products at http://apdrc.soest. hawaii.edu/projects/HRCM/).

An adjusted ratio was computed for each subarea and input to equation 9 to determine the spatial distribution of $V$ for the HRCM A1B 2080-99 future scenario. The adjusted ratio at each subarea was determined from the equation:

$$
w_{\Delta}=\left(F_{\bar{u}_{a n n}} \times \bar{u}_{a n n}\right) \div\left(F_{\bar{P}_{a n n}} \times \bar{P}_{a n n}\right)
$$

where

$$
\begin{aligned}
& \mathrm{w}_{\Delta} \quad \text { is adjusted ratio of mean annual wind speed to } \\
& F_{\bar{u}} \quad \text { is relative change factor for mean annual wind } \\
& \bar{u}_{a n n} \quad \text { is mean annual wind speed developed by } \\
& \text { Johnson and others (2018) }(\mathrm{m} / \mathrm{s}) \text {, } \\
& F_{\bar{P}_{a m}} \quad \text { is relative change factor for mean annual } \\
& \text { rainfall [dimensionless], and } \\
& \bar{P}_{a n n} \quad \text { is mean annual rainfall during 1978-2007 from } \\
& \text { Giambelluca and others (2013) [inches]. }
\end{aligned}
$$

The relative change factors, $F_{\bar{u}}$ and $F_{\bar{P}^{m}}$, at each subarea were calculated for the HRCM 1990-2009 simulation and the HRCM A1B 2080-99 scenarios as follows:

$$
\begin{aligned}
& F_{\bar{u}_{a n n}}=\bar{u}_{f u t} \div \bar{u}_{p r e} \\
& F_{\bar{P}_{a n n}}=\bar{P}_{f u t} \div \bar{P}_{p r e}
\end{aligned}
$$

where

$\bar{u}_{f u t} \quad$ is mean annual wind speed during the HRCM A1B 2080-99 future scenario (m/s),

$\bar{u}_{p r e} \quad$ is mean annual wind speed during the HRCM 1990-2009 simulation (m/s),

$\bar{P}_{f u t} \quad$ is mean annual rainfall during the future scenario $(\mathrm{mm})$, and

$\bar{P}_{\text {pre }} \quad$ is mean annual rainfall during the present-day scenario $(\mathrm{mm})$.

Increases in the values of $V$ in the HRCM A1B 2080-99 scenario are indicated for both leeward and windward parts of west Maui and the western slope of Haleakalā (fig. 8). Conversely, decreases in $V$ are projected for the central and northwest parts of west Maui and much of the eastern parts of Haleakalā. No changes in $V$ are projected for the isthmus and the coastal margins of the leeward part of Maui. Increases in the values of $V$ enhance the potential for greater canopyevaporation rates when compared to present-day conditions. Greater canopy-evaporation rates can affect the water-budget model computations for a forested subarea by enhancing ET, reducing net precipitation, and reducing the amount of water available for groundwater recharge. Conversely, decreases in $V$ suggest the potential for lower canopy evaporation in a forested subarea, which could increase net precipitation and the amount water available for groundwater recharge. The effect of these projected changes in $V$ on groundwaterrecharge rates is examined in the Assessing the Effects of Selected Climate Inputs on Estimated Recharge section.

\section{Potential Evapotranspiration}

The maximum rate of ET from the plant-root zone, referred to as the potential-ET rate, was needed to compute the actual plant-root zone rate of ET in the model. The model computed the potential-ET rate for each subarea as the product of its crop coefficient and reference-ET rate. The reference-ET rate is the ET rate of a hypothetical grass surface of uniform height that is completely shading the ground and has optimum soil-water conditions for given climatic conditions (Allen and others, 1998). Mean annual reference ET ranges from about 28 to 113 inches on Maui (Giambelluca and others, 2014).

Crop coefficients were assigned to each subarea based on the subarea's land-cover type (table 5). The crop coefficients used for this study's scenarios were the same as those used by Johnson and others (2018), except for seed corn. The crop coefficients for corn vary monthly and are based on information in the Hawai' $i$ Agricultural Water Use and Development Plan (University of Hawai' $i, 2008$ ). The crop coefficients used for corn were $0.85,0.50,0.29,0.40,0.80$, $1.20,0.85,0.50,0.29,0.40,0.80$, and 1.20 for the months of January through December, respectively. The values for seed corn were the same as those used in recent water-budget analyses for Kaua'i and O'ahu (Engott and others, 2017; Izuka and others, 2018). For nonforest land-cover classes, crop coefficients integrated the effects of transpiration, ground 


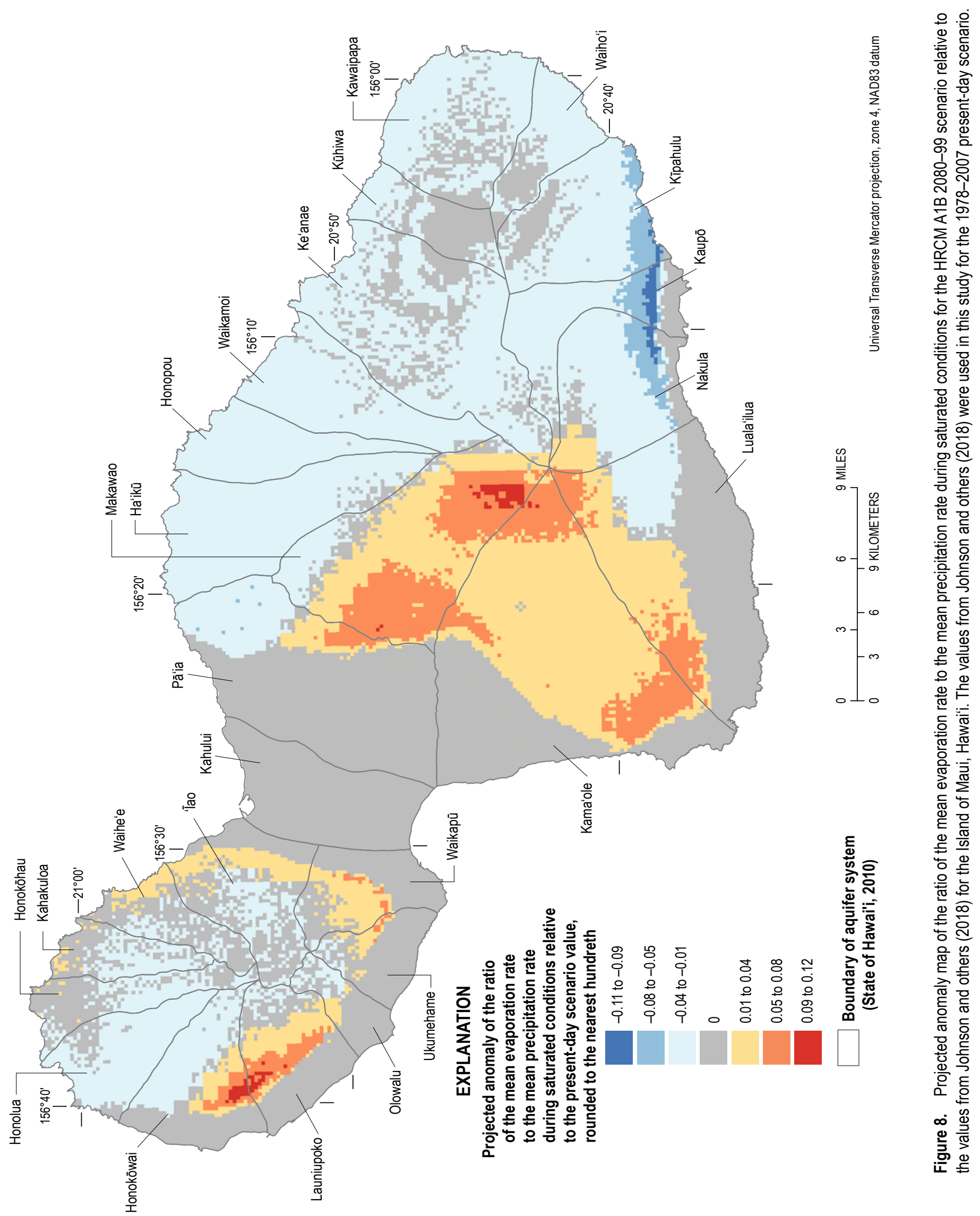


Table 5. Land-cover parameters used in the water-budget calculations for study area on the Island of Maui, Hawai'i.

[Crop coefficients for forests were used to compute the sum of transpiration and ground evaporation; canopy evaporation was computed separately. Crop coefficients for nonforests were used to compute the sum of all evaporative components]

\begin{tabular}{|c|c|c|c|c|c|}
\hline Land-cover description & $\begin{array}{l}\text { Root depth, } \\
\text { in inches }\end{array}$ & $\begin{array}{l}\text { Depletion } \\
\text { fraction }\end{array}$ & $\begin{array}{c}\text { Crop } \\
\text { coefficient }\end{array}$ & $\begin{array}{l}\text { Canopy capacity, } \\
\text { in inches }\end{array}$ & $\begin{array}{c}\text { Trunk-storage capacity, } \\
\text { in inches }\end{array}$ \\
\hline \multicolumn{6}{|c|}{ Forest land covers } \\
\hline Alien forest, no fog & 60 & 0.50 & 0.44 & 0.05 & 0.01 \\
\hline Native forest, fog & 30 & 0.50 & 0.30 & 0.05 & 0.01 \\
\hline Native forest, no fog & 30 & 0.50 & 0.30 & 0.05 & 0.01 \\
\hline Tree plantation, no fog & 60 & 0.50 & 0.44 & 0.05 & 0.01 \\
\hline \multicolumn{6}{|c|}{ Nonforest land covers } \\
\hline Coffee & 48 & 0.40 & 0.91 & 0 & 0 \\
\hline Diversified agriculture & 10 & 0.35 & 1.00 & 0 & 0 \\
\hline Fallow/grassland & 39 & 0.60 & 0.95 & 0 & 0 \\
\hline Taro & 10 & 1.05 & 0.95 & 0 & 0 \\
\hline Developed open space & 12 & 0.50 & 1.18 & 0 & 0 \\
\hline Low-intensity developed & 12 & 0.50 & 1.18 & 0 & 0 \\
\hline Medium-intensity developed & 12 & 0.50 & 1.18 & 0 & 0 \\
\hline High-intensity developed & 12 & 0.50 & 1.18 & 0 & 0 \\
\hline Golf course & 30 & 0.50 & 0.85 & 0 & 0 \\
\hline Grassland & 39 & 0.60 & 0.95 & 0 & 0 \\
\hline Shrubland & 12 & 0.50 & 1.00 & 0 & 0 \\
\hline Sparsely vegetated & 5 & 0.50 & 1.18 & 0 & 0 \\
\hline Reservoir & 1 & 1.00 & 1.05 & 0 & 0 \\
\hline
\end{tabular}

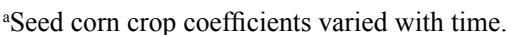

evaporation, and canopy evaporation. For forest landcover classes, crop coefficients integrated the effects of transpiration and ground evaporation only because canopy evaporation was accounted for separately.

For the present-day scenario, monthly reference ET for each model subarea was estimated using maps of mean monthly grass reference surface ET (Giambelluca and others, 2014). These maps also were used to define the spatial distribution of reference ET in the analysis by Johnson and others (2018). In the water-budget calculations, monthly reference ET was not varied from year to year and was assumed to equal mean monthly reference ET. Reference ET was assumed to be the same each day of a given month.
The change-factor approach was used for the HRCM A1B 2080-99 scenario in this study to develop estimates of future mean monthly reference ET by adjusting the maps of mean monthly grass reference surface ET. Relative change factors for monthly reference ET were calculated from the differences in the monthly means of reference ET that were computed using HRCM output for the HRCM 1990-2009 simulation and the HRCM A1B 208099 scenario. The monthly means of reference ET were determined from hourly reference ET that were calculated using the "reduced form" version of the Food and Agriculture Organization of the United Nations Penman-Monteith (FAO-PM) formula described by Allen and others (2006). The HRCM simulation output was used as input to the FAO-PM formula to compute hourly reference ET for each model subarea. 
Hourly reference ET for each subarea was determined from the equation:

$$
E T_{\text {series }}=\frac{0.408 \Delta\left(R_{n}-G\right)+\gamma \frac{37}{T_{2}+273} u_{2}\left(e_{s}-e_{a}\right)}{\Delta+\gamma\left(1+C_{d} u_{2}\right)}
$$

where

$$
\begin{aligned}
& \left.E T_{\text {series }} \text { is hourly grass reference ET [mm/hour }\right] \text { and } \\
& \text { series denotes either the present-day or future } \\
& \text { scenario, } \\
& \Delta \quad \text { is slope of the saturation vapor pressure versus } \\
& \text { temperature curve in kilopascal/temperature } \\
& \text { in degrees Celsius }\left[\mathrm{kPa} /{ }^{\circ} \mathrm{C}\right] \text {, } \\
& R_{n} \quad \text { is net radiation at the surface in megajoule per } \\
& \text { square meter per hour }\left[\mathrm{MJ} / \mathrm{m}^{2} \mathrm{~h}\right] \text {, } \\
& G \quad \text { is sensible heat flux from the surface to the soil } \\
& {\left[\mathrm{MJ} / \mathrm{m}^{2} \mathrm{~h}\right] \text {, }} \\
& \gamma \quad \text { is psychometric constant }\left[\mathrm{kPa} /{ }^{\circ} \mathrm{C}\right] \text {, } \\
& T_{2} \text { is air temperature at } 2-\mathrm{m} \text { height }\left[{ }^{\circ} \mathrm{C}\right] \text {, } \\
& u_{2} \quad \text { is wind speed at } 2-\mathrm{m} \text { height }[\mathrm{m} / \mathrm{s}] \text {, } \\
& e_{s}-e_{a} \quad \text { is saturation vapor pressure deficit }[\mathrm{kPa}] \text {, and } \\
& C_{d} \quad \text { is } 0.24 \text { when } R_{n}>0,0.96 \text { when } R_{n} \leq 0[\mathrm{~s} / \mathrm{m}] \text {. }
\end{aligned}
$$

Net radiation, $R_{n}$, was calculated from HRCM data describing incoming and outgoing short- and long-wave radiation from the following equation (Brutsaert, 2005):

$$
R_{n}=R_{n s}+\varepsilon_{s} R_{d l w}-R_{u l w}
$$

where

$$
\begin{array}{cl}
R_{n s} & \text { is net short-wave radiation }\left(\mathrm{MJ} / \mathrm{m}^{2} \mathrm{~h}\right), \\
\varepsilon_{s} & \text { is surface emissivity (unitless), } \\
R_{d l w} & \text { is downward long-wave radiation }\left(\mathrm{MJ} / \mathrm{m}^{2} \mathrm{~h}\right), \\
& \quad \text { and } \\
R_{u l w} & \text { is upward long-wave radiation }\left(\mathrm{MJ} / \mathrm{m}^{2} \mathrm{~h}\right) .
\end{array}
$$

Net short-wave radiation, $R_{n s}$, and downward long-wave radiation, $R_{d l w}$, were provided by HRCM data. Upward long-wave radiation, $R_{u l w}$, was calculated from HRCM data assuming that the ground, canopy, or water surface under consideration was equivalent to an infinitely deep gray body of uniform temperature and surface emissivity, $\varepsilon_{s}$ (Brutsaert, $2005)$. For this study, the value for surface emissivity, $\varepsilon_{s}$, was assumed to be one $\left(\varepsilon_{s}=1\right)$. Upward long-wave radiation, $R_{u l w}$, was calculated as follows:

$$
R_{u l w}=\varepsilon_{s} \sigma T_{s}^{4}
$$

where

$\sigma \quad$ is Stefan-Boltzman constant $\left[\mathrm{MJ} / \mathrm{m}^{2} \mathrm{~h}\right]$ and

$T_{s} \quad$ is surface skin temperature [Kelvin].
Input values for sensible heat flux, $G$, and air temperature at 2-m height, $T_{2}$, in equation 12, and surface skin temperature, $T_{s}$, in equation 14 were provided by HRCM data. The remaining input parameters in equation 12 were computed using procedures described in Allen and others (1998) for estimating hourly

reference ET and data from HRCM output.

The mean monthly reference ET at each model subarea for the HRCM A1B 2080-99 scenario was determined from the equation:

$$
\overline{E T_{\delta}}(i)=F_{\overline{E T}}(i) \times \overline{E T}_{r e f}(i)
$$

where

$$
\begin{array}{cc}
\overline{E T}_{\delta}(i) \quad \begin{array}{c}
\text { is mean monthly reference ET for month } i \\
\text { during the future simulation [inches], }
\end{array} \\
F_{\overline{E T}}(i) \quad \begin{array}{c}
\text { is relative change factor for mean monthly } \\
\text { reference ET for month } i \text { [dimensionless] }
\end{array} \\
\overline{E T}_{r e f}(i) \quad \begin{array}{l}
\text { is mean monthly grass reference surface ET } \\
\text { for month } i \text { from Giambelluca and others } \\
\end{array} \\
\quad \begin{array}{l}
\text { is variable designating month in a calendar } \\
\text { year. }
\end{array}
\end{array}
$$

The relative change factor, $F_{\overline{E T}}(i)$, for mean monthly reference ET at each model subarea was calculated as follows:

$$
F_{\overline{E T}}(i)=\overline{E T}_{f u t}(i) \div \overline{E T}_{p r e}(i)
$$

where

$$
\begin{aligned}
& \overline{E T}_{\text {fut }}(i) \quad \begin{array}{c}
\text { is mean monthly reference ET for month } i \\
\text { during the HRCM A1B 2080-99 scenario }
\end{array} \\
& \text { [mm] and } \\
& \overline{E T}_{p r e}(i) \quad \begin{array}{c}
\text { is mean monthly reference ET for month } i \\
\text { during the HRCM 1990-2009 simulation } \\
{[\mathrm{mm}] .}
\end{array}
\end{aligned}
$$

The estimates of mean monthly reference ET for the HRCM 1990-2009 simulation and the HRCM A1B 2080-99 scenario were transformed into mean annual reference-ET anomalies for Maui. First, mean annual reference-ET distribution grids were computed for the HRCM 1990-2009 simulation and the HRCM A1B 2080-99 scenario. Next, absolute mean annual reference-ET anomalies, expressed in $\mathrm{mm}$, were computed as the difference between the HRCM A1B 2080-99 scenario means and the HRCM 1990-2009 simulation means for each grid cell. The relative mean annual reference-ET anomalies, expressed as a fraction of the present-day mean, were then computed by dividing the absolute mean reference-ET anomalies by the HRCM 1990-2009 simulation mean for each grid cell (fig. 9). Mean annual reference ET is projected to increase across much of Maui except for the West Maui Mountain and the eastern slopes of Haleakalā where decreases in reference ET are indicated. The greatest increase occurs along the southwest slope of Haleakalā where mean annual 

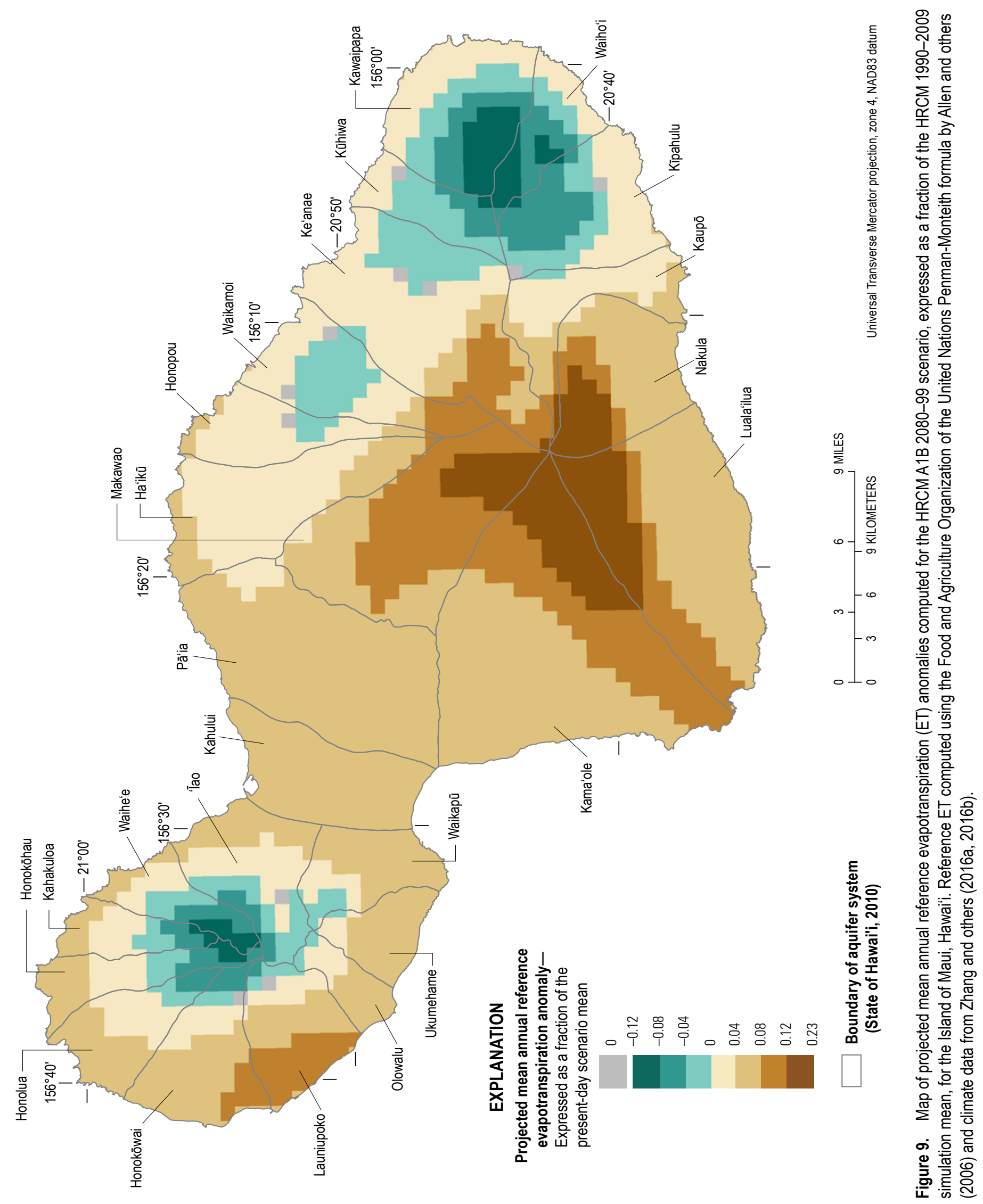
reference ET is projected to increase by as much as 23 percent. The greatest decrease occurs along the eastern slope of Haleakalā where mean annual reference ET is projected to decrease by as much as 12 percent. Island-wide mean annual reference ET is projected to increase by 5 percent.

The climate projection datasets for the SD RCP8.5 2071-99 scenario describe the spatial distribution of potential changes to seasonal rainfall and mean annual surface temperature (Elison Timm and others, 2015; Elison Timm, 2017). However, additional consistently and independently derived meteorological data, such as hourly or daily air temperature, humidity, wind speed, and net radiation are required to estimate reference-ET rates using the FAO-PM equation of Allen and others (2006). Other approaches for estimating reference-ET rates using limited meteorological data are available but many of these methods do not perform well across a wide range of locations and climates (Allen and others, 1998). For example, the Blaney-Criddle method estimates reference ET using only inputs of mean temperature. However, the Blaney-Criddle method underestimates reference-ET rates by as much as 60 percent in windy, dry and sunny areas and overestimates reference-ET rates by as much as 40 percent in calm, humid, and cloudy areas (Brouwer and Heibloem, 1986). Hence, Allen and others (1998) recommend that missing climate data be estimated, whenever feasible, to enable the use of the FAO-PM equation for estimating reference-ET rates. Estimating missing climate data for the SD RCP8.5 2071-99 scenario in order to estimate reference-ET rates using the FAO-PM equation is beyond the scope of this study. For this study, the reference-ET rates used for the 1978-2007 present-day scenario were also used for the SD RCP8.5 2071-99 scenario. An analysis of the effects of potential changes in reference-ET rates on the water-budget model results is included in the Assessing the Effects of Selected Climate Inputs on Estimated Recharge section of this report.

\section{Total Evapotranspiration}

In this study, total ET in each subarea represents the sum of transpiration, ground evaporation, and canopy evaporation. However, the approach used to compute the amount attributable to each ET process varies with land-cover class. For subareas of the non-forest land-cover class, model estimates of plant-root zone ET were used to represent all three ET processes and quantify total ET. For subareas of the forest land-cover class, model estimates of plant-root zone ET were used to represent transpiration and ground evaporation, whereas estimates of ET losses from the rainfallinterception model were used to represent canopy evaporation. Total ET for subareas of the forest land-cover class, including tree plantation, was computed as the sum of plant-root zone ET and canopy evaporation.

Plant-root zone ET for each subarea was computed by the model on the basis of potential ET, moisture storage in the plant-root zone, and threshold-moisture storage, as described in Johnson and others (2018). When moisture storage was greater than or equal to the threshold-moisture storage, the plant-rootzone-ET rate was assumed to equal to the potential-ET rate. When moisture storage was less than the threshold-moisture storage, the plant-root-zone-ET rate was less than the potential-ET rate and declined linearly with soil-moisture content. Threshold-moisture storage was computed on the basis of the depletion fraction and moisture-storage capacity of the plant-root zone (see equation 11 in Johnson and others, 2018). Values for depletion fraction assigned to each land-cover class (table 5) were the same as those used by Johnson and others (2018), except for seed corn. The value for seed corn was the same as that used by Engott and others (2017) and Izuka and others (2018).

\section{Moisture-Storage Capacity of the Plant-Root Zone}

The moisture-storage capacity of the plant-root zone for each subarea was computed by the model as the product of its assigned root depth and the available water capacity of its soil unit (see equation 12 in Johnson and others, 2018). The root depth of each subarea was set to the root depth assigned to its land-cover class. Root depths assigned to each land-cover class (table 5) were the same as those used in previous water budgets for Maui, O'ahu, and Kaua'i (Engott and others, 2017; Izuka and others, 2018; Johnson and others, 2018). The available water capacities of soils were assumed to be time invariant and were estimated from the Natural Resources Conservation Service (2006) soil map and corresponding tables of available water capacities. For each soil unit, the tables listed the minimum and maximum available water capacities for various ranges of depth. A depth-weighted mean of available water capacity was computed for each soil type in the water-budget model. All depths of the "rock outcrop" soil unit, however, had zero available water capacity according to table of Natural Resources Conservation Service (2006). For this study, zero available water capacity was considered too low for this soil unit because many areas with this soil unit on Maui were mapped as grassland or shrubland. Therefore, in the model calculations, the available water-capacity values of the "rock land" soil unit were substituted for all subareas with the "rock outcrop" soil unit. The "rock land" soil unit was selected because it was mapped near "rock outcrop" soils and because its available water capacity exceeded zero in the top eight inches of soil. Moisture storage capacity values for each model period were less than 6 inches for most of the study area but were as high as 10.2 inches in some areas.

\section{Direct Recharge}

Direct recharge in the model represents water seepage that was not subject to the direct runoff or ET process because it bypassed the plant-root zone. Direct recharge in this study was estimated for subareas with cesspool seepage and for subareas of the water body, reservoir, and taro land-cover classes (fig. 4). Methods used to estimate cesspool seepage for each scenario were explained in the Septic Effluent section. Direct recharge rates assigned to land-cover classes of water body ( 0 in/yr), reservoirs within the Pā' 'ia, Kahului, Waikapū, and 'I'ao aquifer systems $(1,268 \mathrm{in} / \mathrm{yr})$, reservoirs in the other 21 aquifer systems ( $528 \mathrm{in} / \mathrm{yr})$, and taro ( $455 \mathrm{in} / \mathrm{yr})$ were the 
same as those used in the model scenarios of Johnson and others (2018). The model scenarios of Johnson and others (2018) reflect 2010 land-cover conditions, which include reservoirs within the $\mathrm{P} \bar{a}$ ' $i a$, Kahului, and Waikapū aquifer systems to support active sugarcane cultivation. However, in the 2017 land-cover map used in this study, the reservoir landcover classes within the Pā'ia, Kahului, and Waikapū aquifer systems were converted to the grassland land-cover class to reflect the cessation of sugarcane cultivation (fig. 4). These direct recharge rates were used in each of the present-day and future scenarios. Direct recharge was allocated in equal amounts to each day of a year in the water-budget model simulations.

\section{Initial Conditions}

In addition to the water-budget inputs already listed, several other parameter inputs were required. The initial moisture storage of the pervious fraction of each subarea was set at 50 percent of its soil moisture-storage capacity. The initial moisture storage of the impervious fraction of each subarea was set at 0.125 inch, equivalent to 50 percent of the rainfallretention capacity of impervious surfaces. These values were used in each of the present-day and future scenarios. These values also were used for other recent water-budget models for Maui (Engott and Vana, 2007; Gingerich and Engott, 2012; Johnson and others, 2018). The effects of these inputs on regional-scale mean annual recharge generally were minor because they either pertained to only a small area or were only applicable during a small fraction of time.

\section{Iteration for the Water-Budget Model}

To mitigate possible effects of arbitrary initial soilmoisture conditions and random selection of monthly rainfall fragment sets (see Initial Conditions and Rainfall sections, above), each scenario of the water-budget model was run for 25 simulations and the scenario's results were averaged. A total of 25 simulations was also used by Johnson and others (2018) and Izuka and others (2018) in their water-budget model scenarios for Maui. To evaluate how the model's recharge estimates changed with number of simulations, the average absolute percentage change in cumulative mean recharge of the study area was computed for each successive simulation of each scenario (fig. 10). A series of cumulative mean recharge values for each scenario was computed by averaging the values from each successive and all preceding simulations. The series of average absolute percentage change values for each scenario was computed by comparing the cumulative mean recharge from each successive simulation with the value from the preceding simulation. The average percentage change for each scenario generally decreased with each successive simulation and was less than 0.002 percent for all scenarios after eight simulations. This very small value, 0.002 percent, was also used by Izuka and others (2018) as the threshold for determining the minimum number of simulations needed.

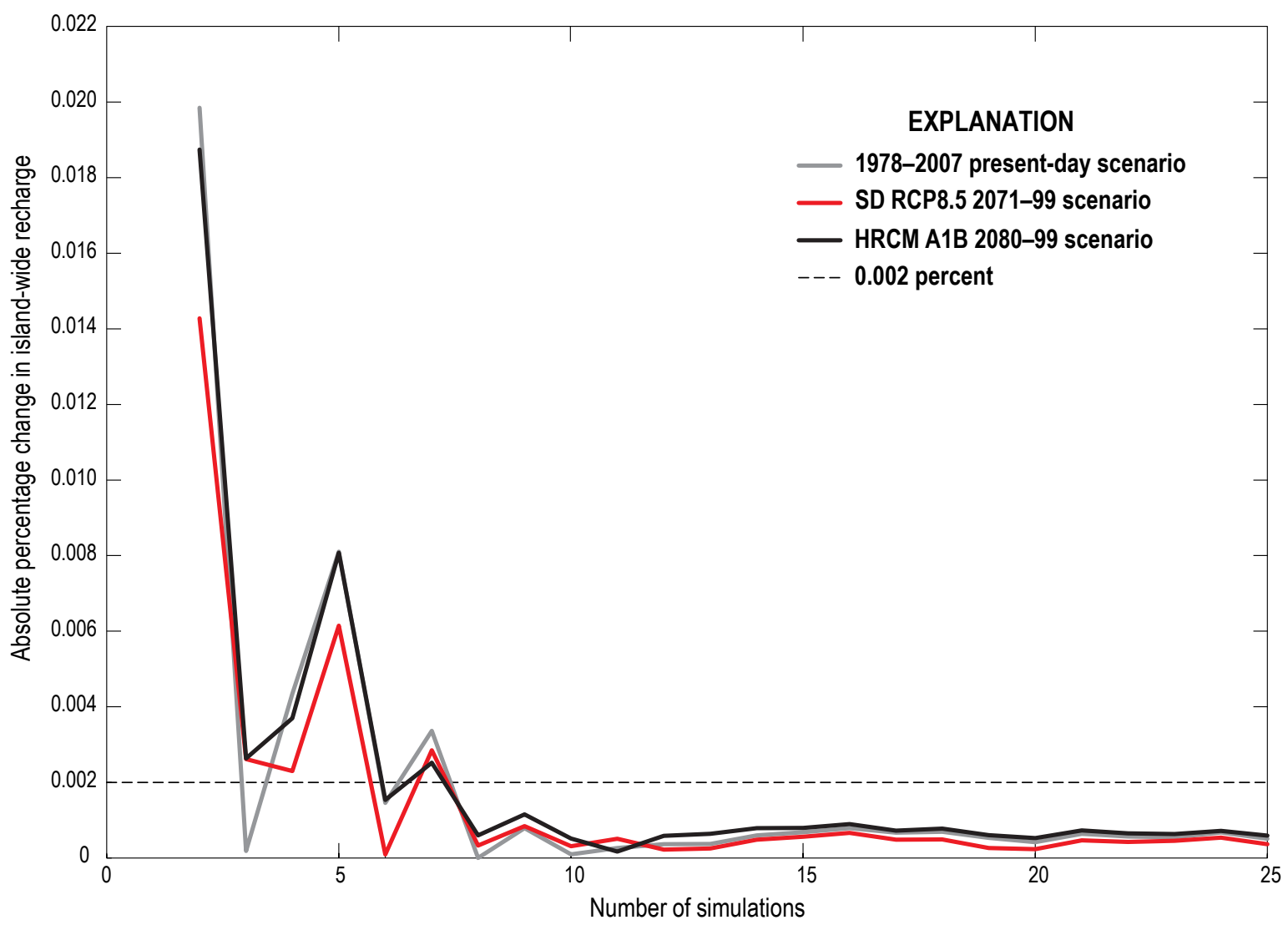

Figure 10. Graph of the absolute percentage change in island-wide recharge with each successive recharge-model simulation for the Island of Maui, Hawaii'i. The dashed line at 0.002 percentage change represents the threshold for determining the minimum number of simulations needed to mitigate the possible effects of arbitrary initial soil-moisture conditions and random selection of monthly rainfall fragments. 


\section{Water-Budget and Groundwater- Recharge Estimates}

The water-budget model was used to compute groundwater recharge and other water-budget components for three selected scenarios: (1) 1978-2007 present-day scenario, (2) SD RCP8.5 2071-99 scenario, and (3) HRCM A1B 2080-99 scenario. Water-budget estimates for each future scenario were compared with estimates from the 1978-2007 present-day scenario to evaluate potential climate-change effects on groundwater recharge and freshwater availability. All scenarios used 2017 land-cover conditions in the water-budget simulations. The water-budget components estimated for the present-day and future scenarios are shown in table 6 and summarized by subarea in Mair (2019a; 2019b; 2019c).

\section{Water-Budget and Recharge Estimates for the 1978-2007 Present-Day Scenario}

Mean annual recharge for the Island of Maui is about 1,232 Mgal/d for the 1978-2007 present-day scenario (table 6). Expressed as a depth of water uniformly distributed over the island, mean annual recharge is about 36 inches. For Maui's 25 aquifer systems (fig. 1), mean annual recharge ranges from about 2.7 to about $219 \mathrm{Mgal} / \mathrm{d}$ for the 1978-2007 present-day scenario (table 6). In terms of recharge expressed as an average depth of water, the aquifer systems with the greatest recharge are Kūhiwa, Kīpahulu, and Ke'anae, which are on east Maui; the aquifer systems with the least recharge are Kahului, Kama'ole, Luala'ilua, and Pā' 'ia, which are on central Maui and leeward Haleakalā. The spatial pattern of mean annual recharge on Maui for the 1978-2007 present-day scenario (fig. 11) resembles the pattern of mean annual rainfall during the same period (fig. 3).

Island-wide mean annual recharge is less than recharge estimated by Johnson and others (2018) by about $77 \mathrm{Mgal} / \mathrm{d}$ (6 percent) mainly because of decreases in irrigation (table 6). The water-budget simulations by Johnson and others (2018) used 2010 land-cover conditions, which included active sugarcane cultivation and irrigation across much of central Maui. However, sugarcane cultivation on Maui ceased in December 2016 and former sugarcane lands were classified as fallow/grassland, an unirrigated land-cover class, for this study (fig. 4). Hence, estimated irrigation across the central part of Maui, including the Kahului and Pā'ia aquifer systems, decreased substantially for this scenario. For example, in the Kahului and Pā' 'ia aquifer systems, total mean annual irrigation and total mean annual recharge are less than irrigation and recharge estimated by Johnson and others (2018) by about 252 and $89 \mathrm{Mgal} / \mathrm{d}$, respectively. Hence, a decrease in recharge is expected because of the cessation of sugarcane cultivation.

\section{Water-Budget and Recharge Estimates for the SD RCP8.5 2071-99 Scenario}

Island-wide mean annual precipitation (rain and fog) for the SD RCP8.5 2071-99 scenario as computed by the water-budget model is less than precipitation for the 1978-2007 present-day scenario by $389 \mathrm{Mgal} / \mathrm{d}$ (13 percent); however, the projected change is not uniform across Maui (table 6). Aquifer-system precipitation decreases in all but three of Maui's 25 aquifer systems. The greatest projected drying occurs in the Kama'ole, Luala'ilua, Makawao, and $P \bar{a}^{\prime}$ ia aquifer systems where decreases in projected aquifersystem precipitation range from 25 to $66 \mathrm{Mgal} / \mathrm{d}$ less than corresponding precipitation for 1978-2007 present-day conditions (table 6). Projected increases in aquifer-system precipitation in the Honopou, Kawaipapa, and Waikamoi aquifer systems range from about 3.4 to $9.8 \mathrm{Mgal} / \mathrm{d}$.

Similar to the change in precipitation, mean annual recharge is projected to decrease across most of Maui for the SD RCP8.5 2071-99 scenario (fig. 12). The island-wide mean annual recharge for the SD RCP8.5 2071-99 scenario is less than recharge for the 1978-2007 present-day scenario by $172 \mathrm{Mgal} / \mathrm{d}$ (14 percent) (table 6). The greatest projected decrease occurs in the wet upland areas of the Honokōwai, Launiupoko, Olowalu, Ukumehame, and Waikapū aquifer systems, where decreases in recharge range from 30 to 51 inches (fig. 12). Increases in recharge are projected for the windward slopes of Haleakalā and areas of land-cover classes that are irrigated, such as coffee and golf courses (fig. 4), where increases as much as 5 inches are projected (fig. 12). Subareas mapped as coffee and golf courses (fig. 4) had slightly more recharge for the SD RCP8.5 2071-99 scenario due to relatively more irrigation. The greatest projected increase in recharge occurs across parts of the Waikamoi aquifer system where increases as much as 15 inches are projected.

Decreases in aquifer-system recharge are projected for all but 3 of Maui's 25 aquifer systems (fig. 13). In terms of absolute changes in mean annual recharge, the greatest decreases in aquifersystem recharge are projected for the Kama'ole, Luala'ilua, and Makawao aquifer systems, where decreases range from 17 to $24 \mathrm{Mgal} / \mathrm{d}$ less than corresponding recharge for the 1978-2007 present-day scenario. In terms of percentage difference from the 1978-2007 present-day scenario, the greatest decreases in aquifer-system recharge are projected for the Kahului, Kama'ole, Luala'ilua, Pā'ia, Waikapū, and Ukumehame aquifer systems, where decreases range from 53 to 72 percent less recharge. Increases in aquifer-system recharge ranging from 1 to 2.4 $\mathrm{Mgal} / \mathrm{d}$ (or about 1 to 3 percent) are projected for the Honopou, Kawaipapa, and Waikamoi aquifer systems. 


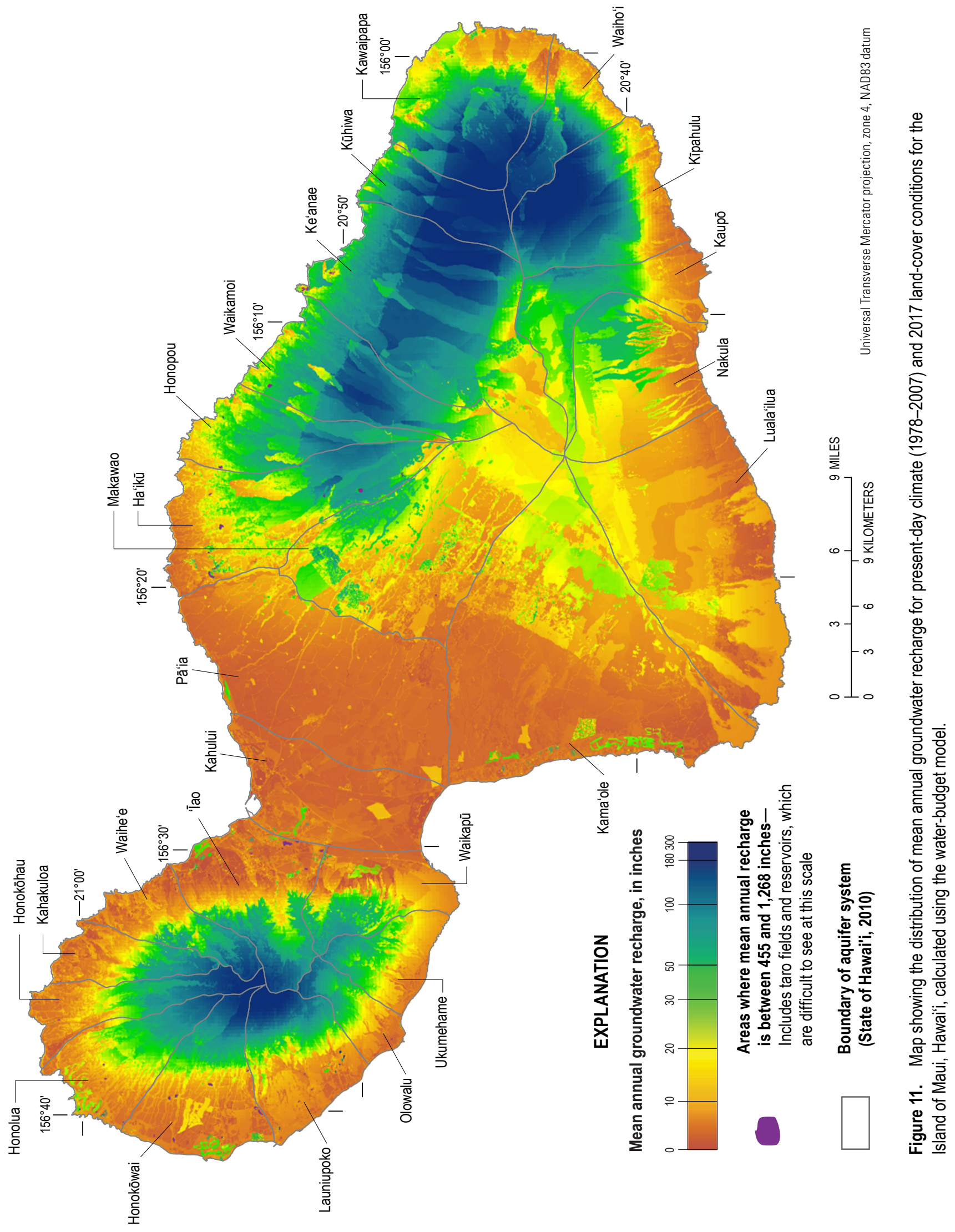



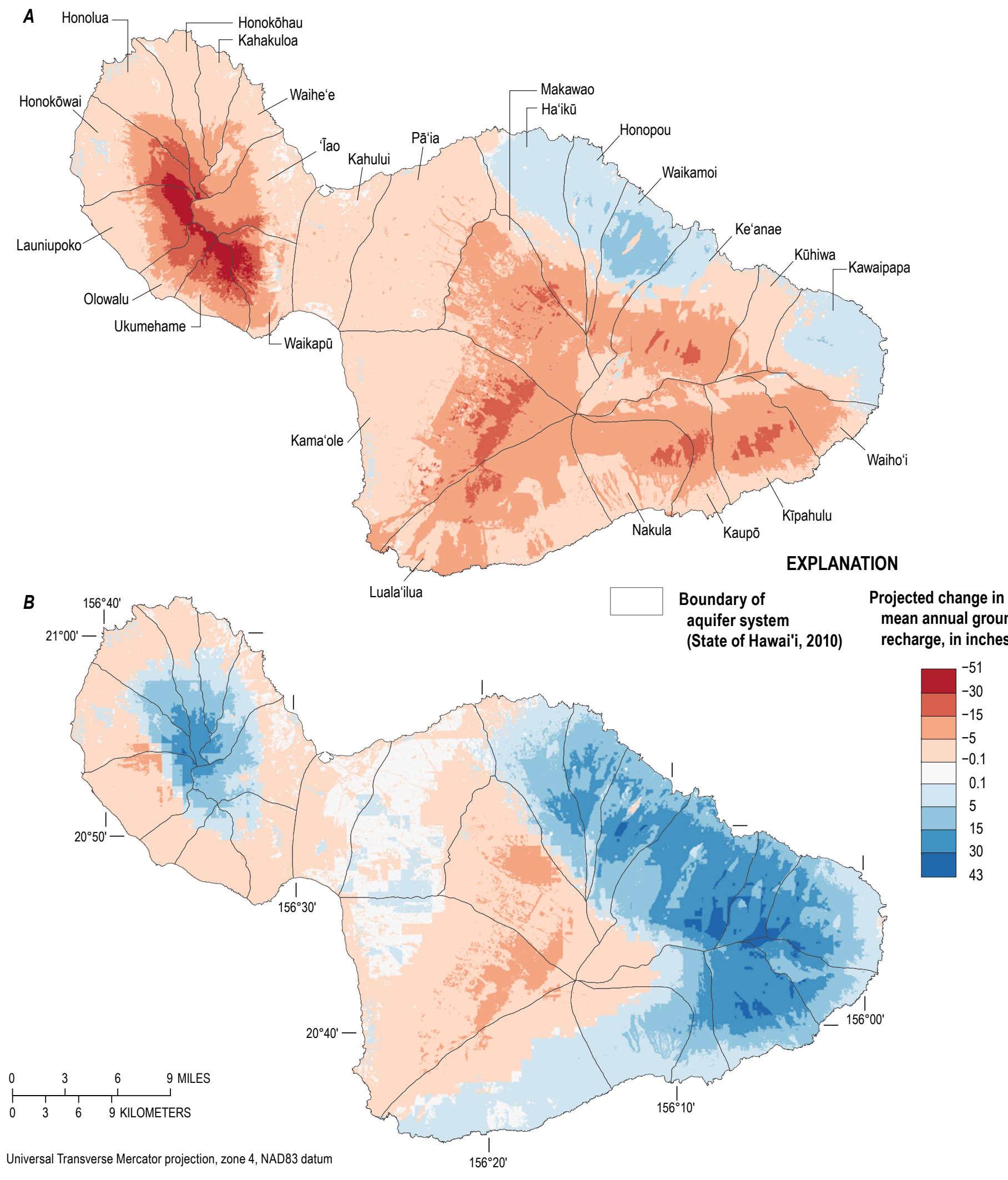

Figure 12. Projected change in mean annual groundwater recharge for two future-climate scenarios for the Island of Maui, Hawaiti. (A) SD RCP8.5 2071-99 scenario from Elison Timm and others (2015), (B) HRCM A1B 2080-99 scenario from Zhang and others (2016b). Projected changes are relative to mean annual recharge for a 1978-2007 present-day scenario. 

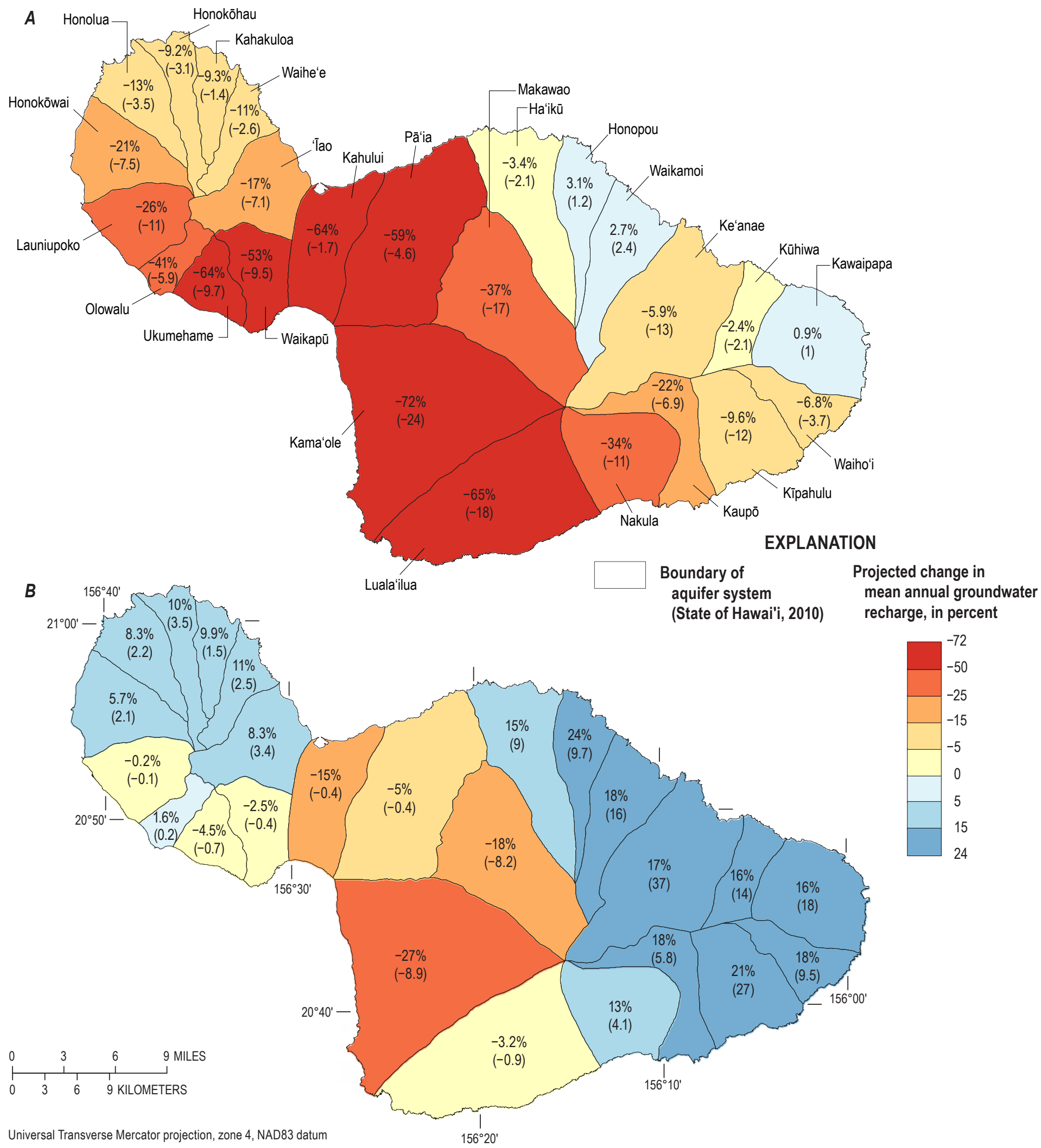

Figure 13. Projected change in mean annual groundwater recharge by aquifer system for two future-climate scenarios for the Island of Maui, Hawaii $i$. (A) SD RCP8.5 2071-99 scenario from Elison Timm and others (2015), (B) HRCM A1B 2080-99 scenario from Zhang and others (2016b). Projected changes are relative to mean annual recharge for a 1978-2007 present-day scenario. Projected change in mean annual groundwater recharge is given both as a percent and as millions of gallons per day in parentheses. 

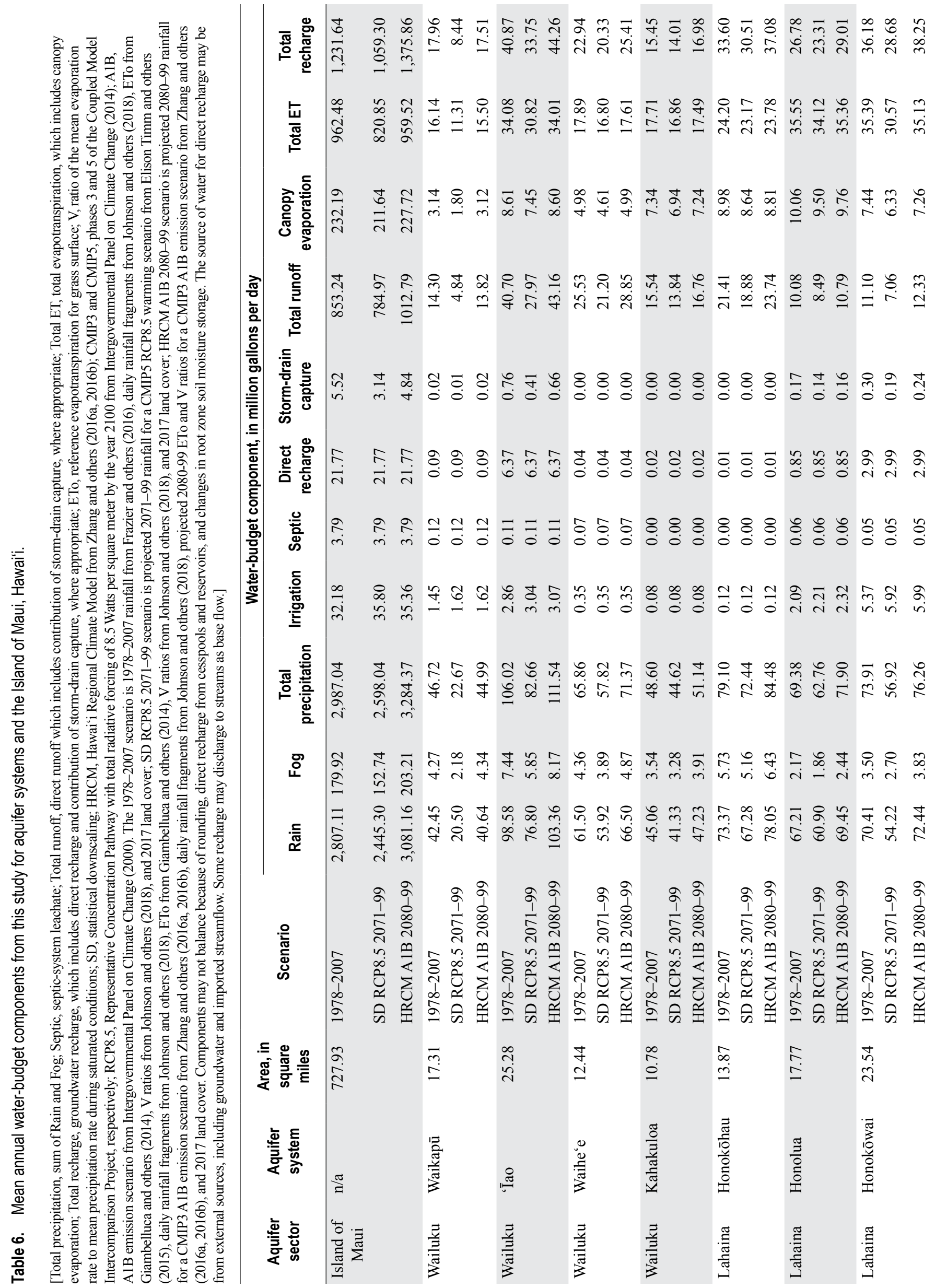


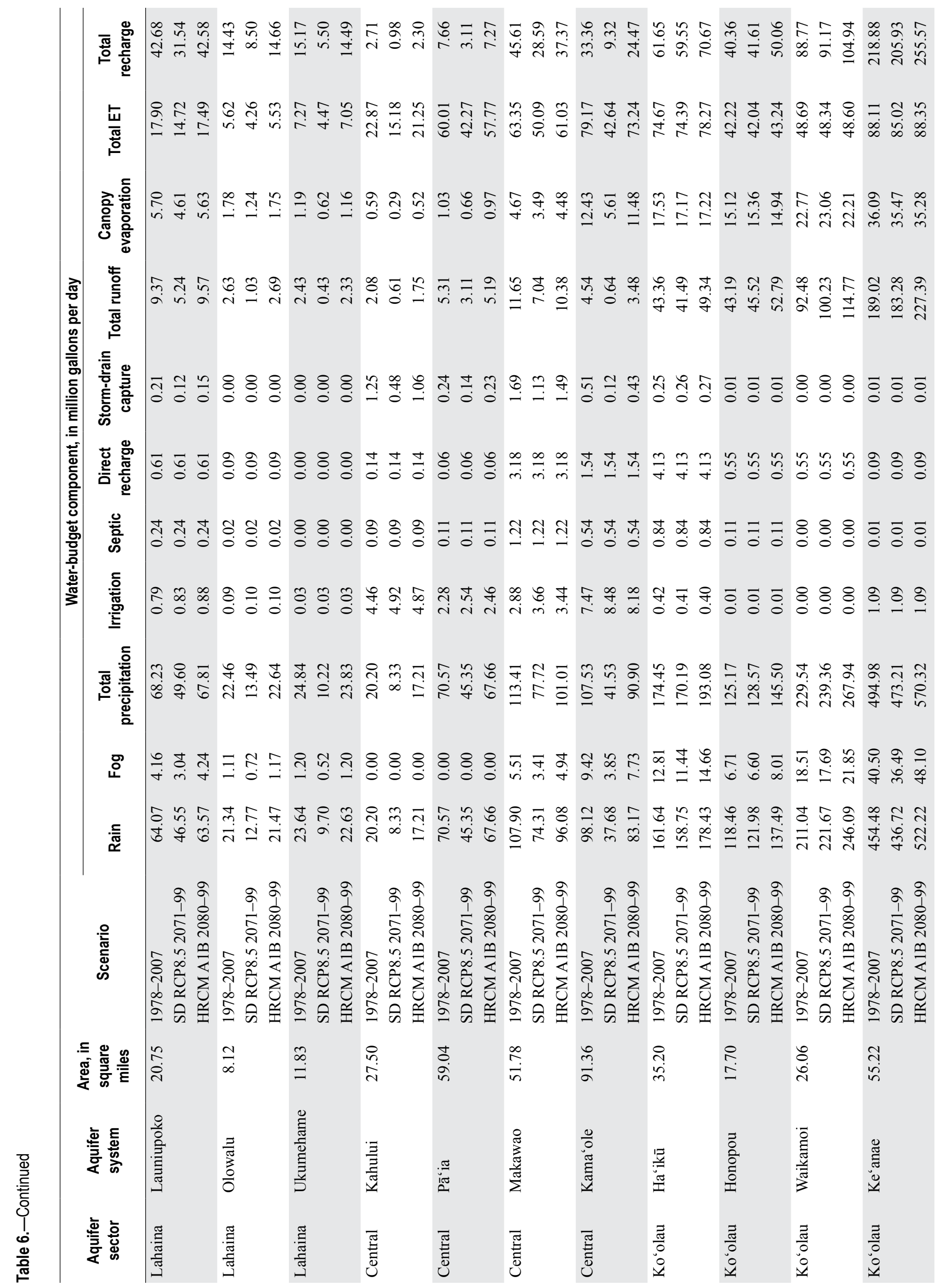




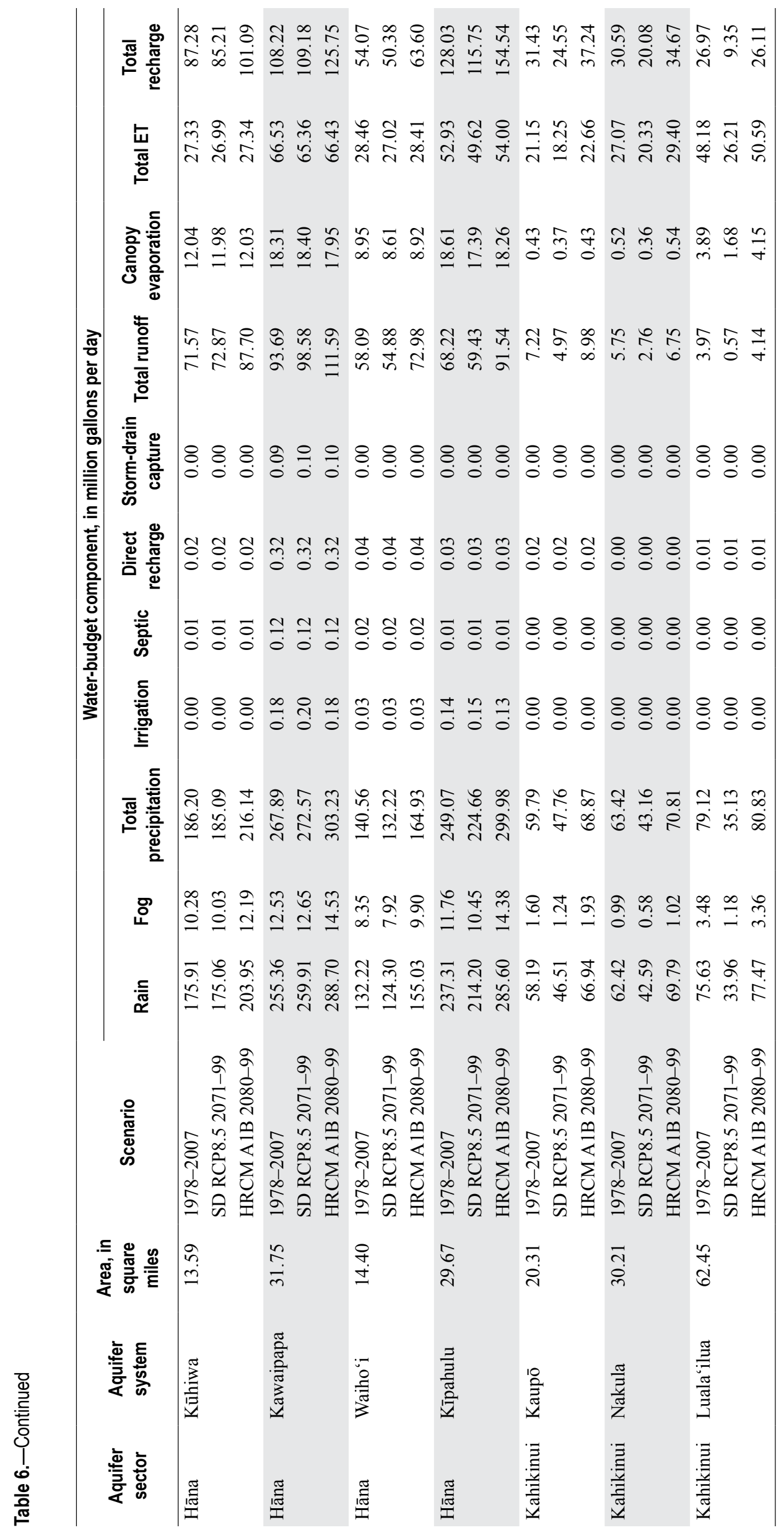




\section{Water-Budget and Recharge Estimates for the HRCM A1B 2080-99 Scenario}

Island-wide mean annual rainfall for the HRCM A1B 208099 scenario as computed by the water-budget model is greater than rainfall for the 1978-2007 present-day scenario by $274 \mathrm{Mgal} / \mathrm{d}$ (10 percent). The island-wide rainfall anomaly as computed by the water-budget model ( 10 percent increase) is less than the island-wide rainfall anomaly computed by Zhang and others (2016a; 2016b) (18 percent increase, table 2) because the rainfall anomalies of Zhang and others (2016a; 2016b) were modified by adjusting their reference period from 1990-2009 to 1978-2007, the reference period of the SD RCP8.5 2071-99 scenario. Islandwide mean annual rainfall during 1990-2009 was less than rainfall during 1978-2007 by about $237 \mathrm{Mgal} / \mathrm{d}$ (8 percent) (Frazier and others, 2016). Hence, the adjustment of rainfall anomalies for the HRCM A1B 2080-99 scenario effectively diminishes the projected increase in island-wide mean annual rainfall from 18 percent, relative to $1990-2009$, to 10 percent, relative to 1978-2007.

The projected changes in precipitation are not uniform across Maui (table 6). Aquifer-system precipitation increases in 18 of 25 aquifer systems. The greatest precipitation increases occur in the Kawaipapa, Ke'anae, Kippahulu, and Waikamoi aquifer systems where projected increases in aquifer-system precipitation range from 38 to $75 \mathrm{Mgal} / \mathrm{d}$ more than the corresponding precipitation of the 1978-2007 present-day scenario. The greatest decreases in precipitation occur in the Kama'ole and Makawao aquifer systems where projected aquifer-system precipitation decreases by 17 and $12 \mathrm{Mgal} / \mathrm{d}$, respectively.

The projected changes in mean annual recharge include a wide range of increases and decreases across large areas of Maui for the HRCM A1B 2080-99 scenario (fig. 12). Island-wide mean annual recharge is more than recharge for the 1978-2007 presentday scenario by about $144 \mathrm{Mgal} / \mathrm{d}$ (12 percent) (table 6). Mean annual recharge is projected to increase in the upland areas of West Maui Mountain, parts of the central isthmus, and the northeast and southeast slopes of Haleakalā. The greatest projected increase in mean annual recharge occurs in the eastern slopes of Haleakalā, where increases range from 30 to 43 inches (fig. 12). A decrease in recharge occurs in the lowland areas of west Maui, parts of the central isthmus, and the western slopes of Haleakalā, where projected recharge rates are as much as 15 inches less than presentday rates.

Increases in aquifer-system recharge are projected for 17 of Maui's 25 aquifer systems (fig. 13). In terms of absolute change, the greatest increases in aquifer-system recharge occur in the Kawaipapa, Ke'anae, Kīpahulu, and Waikamoi aquifer systems, where increases range from 16 to $37 \mathrm{Mgal} / \mathrm{d}$. The greatest increases of aquifer-system recharge, in percentage change from the 1978-2007 present-day scenario, occur in the Honopou, Kaupō, Kīpahulu, Waihoi, and Waikamoi aquifer systems, where increases range from 18 to 24 percent. The greatest decreases in aquifer-system recharge occur in the Makawao and Kama'ole aquifer systems, where decreases are 8 and $9 \mathrm{Mgal} / \mathrm{d}$ (18 and 27 percent), respectively.

\section{Implications of Projected Changes on Groundwater Recharge}

Island-wide recharge is projected to decrease by 14 percent for the SD RCP8.5 2071-99 scenario, in contrast to a projected increase of 12 percent for the HRCM A1B 2080-99 scenario. The two future-climate scenarios analyzed in this study show contrasting changes (opposite direction or sense) in mean annual groundwater recharge across many parts of Maui including the upland areas of the West Maui Mountains, the upland areas of windward Haleakalā, and the southeast part of Haleakalā (fig. 5). Despite opposing island-wide changes, areas of consistent (in terms of direction or sense) wetting and drying also do occur across many parts of Maui. Both future scenarios project a decrease in recharge across three extensive areas of Maui: (1) lowland, coastal areas of West Maui Mountain, (2) the western part of the isthmus that includes parts of the 'Tao, Kahului, and Waikapū aquifer systems, and (3) the summit and western part of Haleakalā crater, and the western slope of Haleakalā that includes parts of Kama'ole, Kaupō, Ke'anae, Luala'ilua, Makawao, and Nakula aquifer systems (fig. 12). Both future scenarios project an increase in recharge across two extensive areas of Maui: (1) windward lowland areas of Haleakalā including parts of Ha'ikū, Honopou, Waikamoi, and Ke'anae aquifer systems and (2) eastern lowland areas of Haleakalā that includes the Kawaipapa aquifer system. Although the change direction is the same in these areas, their change magnitude differs for each climate scenario with lesser increases in recharge projected by the SD RCP8.5 2071-99 scenario and greater increases in recharge projected by the HRCM A1B 2080-99 scenario.

In terms of aquifer-system recharge, agreement in change direction between the two future-climate scenarios is confined to 11 of Maui's 25 aquifers. Both future scenarios project decreases in aquifer-system recharge in a total of eight aquifer systems extending from the southern part of west Maui (Launiupoko, Ukumehame, and Waikapū) across the central part of Maui (Kahului and Pā'ia) to the southwestern slope of Haleakalā (Kama'ole, Luala'ilua, and Makawao) (fig. 13). The magnitude of the decrease in recharge is larger for the SD RCP8.5 2071-99 scenario. Aquifer-system recharge is also projected to increase in the Honopou, Waikamoi, and Kawaipapa aquifer systems for both future-climate scenarios, though by a larger magnitude in the HRCM A1B 2080-99 scenario. The remaining 14 aquifer systems on Maui, including the aquifers in the northern part of west Maui and the eastern part of Haleakalā, show contrasting changes in projected aquifer-system recharge for both futureclimate scenarios. The contrast in change direction and change magnitude between the two future-climate scenarios provides a range of uncertainty among available climate projections and their projected impacts on groundwater recharge on Maui, although the range may not necessarily capture the true future conditions.

The results of this study indicate projected changes in the amount and distribution of groundwater recharge on Maui that could affect groundwater availability. These changes in recharge could affect CWRM's calculation of sustainable-yield values for Maui's aquifer systems. Furthermore, these changes 
in recharge could also affect groundwater levels and salinity in production wells that supply potable drinking water. Changes in recharge could also affect aquatic ecosystems on Maui that rely on groundwater discharge to streams and nearshore marine environments. It is beyond the scope of this study to assess the range of effects to groundwater availability from the projected changes in groundwater recharge for the two future-climate scenarios included in this study.

\section{Assessing the Effects of Selected Climate Inputs on Estimated Recharge}

In this study, a set of water-budget model inputs were developed on the basis of projected changes in climate for two future-climate scenarios. The model inputs were then used in the water-budget model to estimate groundwater recharge and other water-budget components. To analyze the effect that future-scenario model inputs have on estimated recharge, the water budget was rerun, including one input at a time for a future climate condition while keeping all other model inputs the same for a present-day climate condition. The HRCM A1B 2080-99 scenario was used as the future-climate scenario for this analysis. The input parameters tested were (1) monthly rainfall and seasonal runoff-to-rainfall ratios, (2) daily rainfall fragments, (3) mean monthly reference ET, (4) the ratio of the mean evaporation rate to mean precipitation rate during saturated conditions, $V$, and (5) the combination of all preceding four sets of parameters. The monthly rainfall and seasonal runoff-to-rainfall ratio datasets were treated as one parameter input because the estimation of runoff for the future scenarios is calculated entirely from rainfall in this study (see Direct Runoff section). The daily rainfall fragments datasets for the present-day and future climate conditions were developed using the climate datasets from the HRCM 1990-2009 simulation and HRCM A1B 2080-99 scenario.

The recharge estimates for these analyses were compared with recharge estimates of a 1978-2007 present-day scenario for the Honokōwai, Honopou, 'Īao, Kama'ole, and Kīpahulu aquifer systems, and the Island of Maui as a whole (table 7). These five aquifer systems cover a range of climates on Maui. The Honokōwai and 'Tao aquifer systems are on leeward and windward West Maui Mountain, respectively, and have steep rainfall gradients. The wet uplands of the Honokōwai aquifer system are mostly native forest; drier lowlands include alien forest, coffee, developed areas, and large areas of abandoned pineapple fields that are now fallow grasslands. Within the 'Tao aquifer system, uplands are wet, steep, and mostly forest and shrubland; lowlands are drier and are a mixture of alien forest, macadamia, grassland, and developed areas. The Kīpahulu and Honopou aquifer systems are on leeward and windward Haleakalā, respectively, and have steep rainfall gradients. The upland areas of the Kippahulu and Honopou aquifer systems are wet, steep, and mostly alien and native forests, and areas below the fog zone are mostly alien forest and grassland. The area of the Kama'ole aquifer system covers a large part of leeward Haleakalā and is relatively dry. The uplands area of the Kama'ole aquifer system is a mixture of alien and native forest, grassland, and developed areas; areas below the fog zone are mostly alien forest, grassland, sparsely vegetated, and developed areas. Also, the Honopou and Kama'ole aquifer systems represent the two aquifer systems with the greatest percentage change in simulated recharge in terms of wetting (Honopou) and drying (Kama'ole) changes of the HRCM A1B 2080-99 scenario.

The monthly rainfall and seasonal runoff-to-rainfall ratios have the largest influence on recharge estimates among the four parameter inputs for the five aquifer-systems and the Island of Maui (table 7). The dependence of recharge estimates on monthly rainfall and fog interception, which is computed as a fraction of rainfall in the model, is expected since 98 percent of the total water input for the Island of Maui is derived from rain and fog (for example, see the 1978-2007 present-day scenario in table 6) (note, irrigation for the water-budget model may be derived from groundwater or surface-water sources that are considered separate from rain and fog in terms of water input). If monthly rainfall and seasonal runoff-to-rainfall ratios are the only changes included in the future-scenario simulation, then projected changes in aquifer-system recharge for three of the five aquifer systems and the Island of Maui come close to matching the values estimated when the projected changes for all four model input parameters are included (table 7). For example, the projected changes in recharge in the Honokōwai, Honopou, and Kippahulu aquifer systems, and the Island of Maui are within 7 percent of the projected changes considering all combined effects. However, the projected decrease in recharge in the Kama'ole aquifer system is underestimated by 17 percent (1.4 Mgal/d) when compared to the estimated decrease considering all combined effects. In the 'Tao aquifer system, the projected increase in recharge is underestimated by 14 percent $(0.5 \mathrm{Mgal} / \mathrm{d})$.

Recharge estimates in the Kama'ole aquifer system are also affected by adjustments in mean monthly reference ET. Including future mean monthly reference ET decreases recharge in the Kama'ole aquifer system by $1.5 \mathrm{Mgal} / \mathrm{d}$ (5.2 percent), which is 19 percent of the estimated decrease considering all combined effects (table 7). Future mean monthly reference ET in the other four aquifer systems causes relatively small decreases (Honokōwai and Honopou) or increases ('Tao and Kīpahulu) in recharge. For the Island of Maui, including future mean monthly reference ET decreases island-wide recharge by $8.3 \mathrm{Mgal} / \mathrm{d}$ (or 0.7 percent) (table 7) despite an island-wide increase of 5 percent in mean annual reference ET (fig. 9).

Unlike the other four aquifer systems, mean annual reference ET is projected to increase across all of the Kama' ole aquifer system for the HRCM A1B 2080-99 scenario (fig. 9). Furthermore, the Kama'ole aquifer system includes upland areas along the southwest slope of Haleakalā where the greatest increases in mean annual reference ET are projected for the Island of Maui. The upland areas of the 'Īao and Kippahulu aquifers include extensive areas where mean annual reference ET is projected to decline (fig. 9), which causes an increase in recharge. This island-wide disparity is due to the disproportionate effect of the non-uniform spatial distribution of projected changes in 
reference ET in wet and dry areas of Maui. The greatest projected increases in reference ET across Maui occur in dry areas with relatively low recharge, whereas the greatest projected decreases in reference ET occur in wet areas with relatively high recharge (fig. 11). Hence, in terms of island-wide recharge, reduced recharge caused by increases in reference ET across extensive dry, low-recharge areas is being largely offset by increased recharge caused by decreases in reference ET in wet, high-recharge areas.

Including future estimates of $V$ increased recharge in four of the five aquifer systems. The greatest increases occurred in the Honopou and Kīpahulu aquifer systems where recharge estimates increased by $1.3 \mathrm{Mgal} / \mathrm{d}$ ( 3.5 percent) and $1.7 \mathrm{Mgal} / \mathrm{d}$ (1.4 percent) (table 7), respectively. Estimates of $V$ decrease across much of the forested areas of the Honopou and Kippahulu aquifer systems (fig. 8), which effectively reduces canopy evaporation and increases recharge in the water-budget model calculations. The upland and lowland areas of the Honopou aquifer system are largely wet and forested (fig. 4), where canopy evaporation can influence the water budget (Johnson and others, 2018). Reductions in $V$ are also projected across parts of the upland forested areas of the 'Tao and Honokōwai aquifer systems; increases in recharge estimates in these aquifer systems are $0.2 \mathrm{Mgal} / \mathrm{d}$ ( 0.4 percent) and $0.3 \mathrm{Mgal} / \mathrm{d}$ ( 0.8 percent) (table 7$)$, respectively. Increases in $V$ are projected across much of the forested areas in the Kama'ole aquifer system (fig. 8) and result in a decrease of $0.5 \mathrm{Mgal} / \mathrm{d}$ (or 1.9 percent) in estimated recharge (table 7). The inclusion of future $V$ for the Island of Maui increases the island-wide recharge estimate by $11.5 \mathrm{Mgal} / \mathrm{d}$ (or 1 percent). Increases in $V$ are projected for mostly dry areas around West Maui Mountain and along the western slope of Haleakalā (fig. 8). Decreases in $V$ are projected across much of the wet, forested areas of the West Maui Mountains and eastern part of Haleakalā. The increases in estimated recharge in wet, forested areas with reduced $V$ more than compensate for the decreased recharge rates in areas with increased $V$ resulting in a net positive effect on island-wide recharge.

Daily rainfall fragments control the magnitude and timing of daily rainfall within a given month in the water-budget model simulations for each scenario. Hence, including future daily rainfall fragments can induce changes in the patterns of daily rainfall, which can increase or decrease recharge estimates in a given month. Future patterns of daily rainfall that concentrate the amount of rainfall during a given month over a fewer number of days (higher fragment values, fewer non-zero fragments) can result in decreased canopy evaporation and increased recharge when compared to the present-day climate condition. Conversely, future patterns that distribute the amount of rainfall during a given month over a greater number of days (lower fragment values, more non-zero fragments) can increase canopy evaporation and decrease recharge. For example, the inclusion of future daily rainfall fragments increases recharge in the 'Tao and Kama'ole aquifer systems by 0.7 percent or less, whereas its inclusion decreases recharge in the Honokōwai, Honopou, and Kīpahulu aquifer systems and the Island of Maui by 1.4 percent or less (table 7). The opposing changes in recharge among the five aquifer systems examined in this analysis suggest non-uniform impacts from changes in daily rainfall patterns across Maui for the HRCM A1B 2080-99 scenario.

Table 7. Results of testing for selected water-budget model input parameters performed for selected aquifer systems and the Island of Maui, Hawaili

[HRCM, Hawai' i Regional Climate Model from Zhang and others (2016a, 2016b); CMIP3, phase 3 of the Coupled Model Intercomparison Project; A1B, A1B emission scenario from Intergovernmental Panel on Climate Change (2000). Present-day climate condition is 1978-2007 present-day scenario and daily rainfall fragments from HRCM 1990-2009 simulation from Zhang and others (2016a); future climate condition is HRCM A1B 2080-99 scenario from Zhang and others (2016b)]

Change in recharge for future climate condition relative to present-day climate condition for selected aquifer

Parameter systems and the Island of Maui, in percent; (change in million gallons per day)

\begin{tabular}{|c|c|c|c|c|c|c|}
\hline & & & & & & \\
\hline & Honokōwai & Honopou & 'T̄ao & Kama'ole & Kīpahulu & Island of Maui \\
\hline $\begin{array}{l}\text { Monthly rainfall, seasonal } \\
\text { runoff-to-rainfall ratios }\end{array}$ & $5.7(2.0)$ & $21.9(8.4)$ & $8(3.1)$ & $-23.6(-6.7)$ & $19.5(24.1)$ & $11.8(137.6)$ \\
\hline $\begin{array}{l}\text { Ratio of the mean evaporation } \\
\text { rate to mean precipitation } \\
\text { rate during saturated } \\
\text { conditions, } V\end{array}$ & $0.8(0.3)$ & $3.5(1.3)$ & $0.4(0.2)$ & $-1.9(-0.5)$ & $1.4(1.7)$ & $1(11.5)$ \\
\hline $\begin{array}{l}\text { Monthly rainfall; seasonal } \\
\text { runoff-to-rainfall ratios; daily } \\
\text { rainfall fragments; mean } \\
\text { monthly reference ET; ratio of } \\
\text { the mean evaporation rate to } \\
\text { mean precipitation rate during } \\
\text { saturated conditions, V }\end{array}$ & $5.8(2)$ & $23.3(9)$ & $9(3.6)$ & $-28.5(-8.1)$ & $20.6(25.6)$ & $11.7(135.6)$ \\
\hline
\end{tabular}




\section{Study Limitations}

This study relies on the availability of various types of physical data for simulating hydrological processes and physical conditions that affect groundwater recharge for a set of future conditions. Lack of data or sparse, uneven distribution of data in space and time, and poor understanding of some hydrologically relevant processes limit the precision and accuracy of study results. This section reviews the limitations imposed by the present set of climate projections and the transformation of these climate datasets into waterbudget model inputs for simulating the projected effects on groundwater recharge and other water-budget components. Information that could advance future efforts to more accurately assess the projected effects of future climate conditions on groundwater availability for the Island of Maui is also discussed. Detailed descriptions of the water-budget model exclusions and limitations are provided in Johnson and others (2018) and Izuka and others (2018).

Dissimilar simulation periods between the sets of climate projections-The climate projections of the two future scenarios reflect departures from climate conditions during different reference periods (1978-2007 and 1990-2009). The rainfall projections of the SD RCP8.5 2071-99 scenario represent a 2071-99 time period relative to a 1978-2007 reference period, whereas the climate projections for the HRCM A1B 2080-99 scenario characterize future climate for a 2080-99 time period relative to a 1990-2009 reference period. Although the two present-day scenarios overlap during an 18-year period during 1990-2007, the 1990-2009 present-day scenario represents a distinctly drier baseline condition compared to the 1978-2007 present-day scenario. The differences in baseline conditions may be a contributing factor to the identified changes for each futureclimate scenario. However, it is beyond the scope of this study to assess the extent to which these differences in baseline conditions affect the drying and wetting changes identified in this study for each future-climate scenario. These differences in future time periods and baseline conditions preclude direct comparisons of the two future-climate scenarios if adjustments are not made to account for the different baseline conditions. In this study, an approach was developed to modify rainfall projections for the HRCM A1B 2080-99 scenario to reflect the same 1978-2007 present-day reference period used by the SD HRCM 2071-99 scenario. This approach enabled a direct comparison of both future scenario water-budget simulations to a common reference period. However, the approach used in this analysis may not completely compensate for the potential inherent biases of the two downscaling approaches and their respective reference climate condition. An evaluation of the potential biases of each downscaling approach with respect to their reference climate condition is beyond the scope of this study. Recharge estimates for multiple future-climate scenarios could be improved with the availability of climate projections that use common reference and projection time periods.

Projected rainfall-The results of this study indicate that precipitation is a critical dataset for estimating recharge. The two climate projections used in this study characterize a wide range of projected changes in rainfall resulting in opposing drying and wetting changes across many parts of Maui. Less uncertainty in projected changes in rainfall would reduce uncertainty in quantifying potential influences on recharge and groundwater availability. Also, the projected effects of potential changes to daily rainfall frequency on recharge and other waterbudget components could not be simulated for the SD RCP8.5 2071-99 scenario because consistently developed estimates of daily rainfall frequency were not available for this scenario. Recharge estimates for future conditions can be improved with information on projected changes in daily rainfall frequency for the wide range of projected changes in rainfall.

Projected fog interception - Projected impacts of potential changes to fog-interception rates and their effect on recharge and other water-budget components could not be simulated for both future-climate scenarios. Fog interception may provide a substantial part of the water available for recharge over large areas of Maui. Hence, recharge estimates for multiple future-climate scenarios can be improved with information that describes the potential changes in fog-interception rates for future conditions.

Projected evapotranspiration-The projected impacts of potential changes to canopy-evaporation and reference ET rates on recharge and other water-budget components could not be simulated for the SD RCP8.5 2071-99 scenario because consistently developed projections for canopy evaporation and reference ET were not available for this scenario. Improved spatial estimates of $V$, the ratio of the mean evaporation rate to the mean precipitation rate during saturated canopy conditions, would be helpful for estimating the projected effects on canopy evaporation for present-day and future climate conditions.

Effects of increased atmospheric carbon dioxide $\left(\mathrm{CO}_{2}\right)$ concentrations on recharge estimates-The analyses conducted in this study do not consider the potential effects of projected increases in atmospheric $\mathrm{CO}_{2}$ concentrations on estimates of recharge and other water-budget components. Increases in $\mathrm{CO}_{2}$ concentrations may act to suppress ET by decreasing plant leaf stomatal conductance, which can increase soil moisture available for recharge. However, the extent to which increased soil moisture could enhance recharge estimates because of increased $\mathrm{CO}_{2}$ concentrations was not evaluated. Therefore, the recharge estimates described in this study may be considered conservative with respect to the potential influence of increased $\mathrm{CO}_{2}$ concentrations. Recharge estimates for future climate conditions can be improved by considering the potential effects of increased $\mathrm{CO}_{2}$ concentrations.

Land Cover-The effects of future land-cover conditions on recharge and other water-budget components were not considered in this study. Maps of future land-cover conditions on Maui would be helpful for evaluating the effects of (1) planned development, (2) climate-induced changes in the distribution of the dominant types of forest species, and (3) watershed management and restoration efforts. The approach used for this study, however, did allow for isolating the effects of climate change on recharge by excluding the complicating factor of changing land cover. 


\section{Summary}

The main objectives of this study were to (1) produce spatially distributed estimates of mean groundwater recharge and other water-budget components for three climate scenarios including a 1978-2007 present-day scenario, an SD RCP8.5 2071-99 scenario, and an HRCM A1B 2080-99 scenario, and (2) quantify the regional hydrologic changes between presentday and future-climate scenarios. Recharge was computed with a water-budget model that used a daily computation interval. Hydrologic processes and physical conditions that affect recharge on Maui for present-day and future climate conditions were simulated in the water-budget model using the most recent datasets available - including maps of 2017 land cover, 1978-2007 monthly rainfall, and mean monthly reference ET. Published high-resolution downscaled climate projections were used to modify inputs of monthly rainfall, daily rainfall frequency, mean monthly reference ET, and forest-canopy evaporation for simulating the impacts of future climate conditions.

For the SD RCP8.5 2071-99 scenario, island-wide mean annual precipitation (rain and fog) is less than precipitation for the $1978-2007$ present-day scenario by $389 \mathrm{Mgal} / \mathrm{d}$ (13 percent); however, the projected change is not uniform across Maui. Aquifer-system precipitation decreases in all but three of Maui's 25 aquifer systems, which are management systems defined by the Hawai' $i$ Commission on Water Resource Management. The greatest drying occurs in the Kama'ole, Luala'ilua, Makawao, and Pā'ia aquifer systems where projected decreases in precipitation range from 25 to $66 \mathrm{Mgal} / \mathrm{d}$ less than corresponding precipitation for 1978-2007 present-day conditions. Projected increases in aquifer-system precipitation in the Honopou, Kawaipapa, and Waikamoi aquifer systems range from about 3.4 to $9.8 \mathrm{Mgal} / \mathrm{d}$. Island-wide mean annual recharge is projected to be less than recharge for the 1978-2007 present-day scenario by $172 \mathrm{Mgal} / \mathrm{d}$ (14 percent). Aquifer-system recharge is projected to decrease in all but three of Maui's 25 aquifer systems. The greatest reductions occur in the Kama'ole, Luala'ilua, and Makawao aquifer systems, where decreases range from 17 to $24 \mathrm{Mgal} / \mathrm{d}$ less recharge than corresponding recharge for the 1978-2007 present-day scenario. Increases in aquifer-system recharge ranging from 1 to $2.4 \mathrm{Mgal} / \mathrm{d}$ (or about 1 to 3 percent) are projected for the Honopou, Kawaipapa, and Waikamoi aquifer systems.

For the HRCM A1B 2080-99 scenario, island-wide mean annual precipitation is more than precipitation for the 1978-2007 present-day scenario by $297 \mathrm{Mgal} / \mathrm{d}$ (10 percent). Aquifer-system precipitation increases in 18 of 25 aquifer systems. The greatest precipitation increases occur in the Kawaipapa, Ke'anae, Kīpahulu, and Waikamoi aquifer systems where projected aquifer-system precipitation increases range from 35 to $75 \mathrm{Mgal} / \mathrm{d}$ more than corresponding precipitation for the 1978-2007 present-day scenario. The greatest decreases in precipitation occur in the Kama'ole and Makawao aquifer systems where projected aquifer-system precipitation decreases by 17 and $12 \mathrm{Mgal} / \mathrm{d}$, respectively. Estimated island-wide mean annual recharge is more than recharge for the 1978-2007 present-day scenario by about $144 \mathrm{Mgal} / \mathrm{d}$ (12 percent). Increases in aquifer-system recharge are projected for 17 of Maui's 25 aquifers. The greatest increases in aquifer-system recharge occur in the Kawaipapa, Ke'anae, Kīpahulu, and Waikamoi aquifer systems, where increases range from 16 to $37 \mathrm{Mgal} / \mathrm{d}$ (16 to 21 percent). The greatest decreases in aquifer-system recharge occur in the Makawao and Kama'ole aquifer systems, where decreases are 8 and $9 \mathrm{Mgal} / \mathrm{d}$ (18 and 27 percent), respectively.

Agreement in drying or wetting between the two futureclimate scenarios is limited to 11 of Maui's 25 aquifers. Projected decreases in aquifer-system recharge are indicated for both future scenarios in a total of eight aquifer systems extending from the southern part of west Maui (Launiupoko, Ukumehame, and Waikapū) across the central part of Maui (Kahului and Pā'ia) to the southwestern slope of Haleakalā (Kama'ole, Luala'ilua, and Makawao). Aquifer-system recharge is projected to increase for both future-climate scenarios in the Honopou, Waikamoi, and Kawaipapa aquifer systems. Despite their agreement in change direction, the magnitude of the changes in aquifer-system recharge vary for each futureclimate scenario with greater decreases projected for the SD RCP8.5 2071-99 scenario and greater increases projected for the HRCM A1B 2080-99 scenario. The remaining 14 aquifer systems on Maui, including the aquifers in the northern part of west Maui and the eastern part of Haleakalā, show contrasting changes in projected aquifer-system recharge for both futureclimate scenarios. Greater consistency in projected changes to rainfall between future-climate scenarios would help reduce the uncertainty associated with quantifying the effects on recharge and groundwater availability.

Among the four inputs analyzed for their effect on recharge estimates, projected changes in monthly rainfall and seasonal runoff-to-rainfall ratios (considered as a single factor) have the greatest impact on recharge estimates for the Honokōwai, Honopou, 'T̄ao, Kama'ole, and Kīpahulu aquifer systems, and the Island of Maui in the HRCM A1B 2080-99 climate scenario. The projected changes in monthly rainfall and seasonal runoff-to-rainfall ratios (relative to considering all four inputs combined) account for 83 percent or more of the projected change in aquifer-system recharge for these five aquifer systems and island-wide recharge for the Island of Maui. Projected changes in aquifer-system recharge and island-wide recharge are affected less by projected changes in reference ET, forest-canopy evaporation, and daily rainfall frequency. 


\section{References Cited}

Allen, R.G., Pereira, L.S., Raes, D., and Smith, M., 1998, Crop evapotranspiration - Guidelines for computing crop water requirements - FAO Irrigation and drainage paper 56: Food and Agriculture Organization of the United Nations, $300 \mathrm{p}$.

Allen, R.G., Pruitt, W.O., Wright, J.L., Howell, T.A., Ventura, F., Snyder, R., Itenfisu, D., Steduto, P., Berengena, J., Yrisarry, J.B., Smith, M., Pereira, L.S., Raes, D., Perrier, A., Alves, I., Walter, I., and Elliot, R., 2006, A recommendation on standardized surface resistance for hourly calculation of reference ET by the FAO56 Penman-Monteith method: Agricultural Water Management, v. 81, no. 1-2, p. 1-22.

Bassiouni, M., and Oki, D.S., 2013, Trends and shifts in streamflow in Hawai' 1 , 1913-2008: Hydrological Processes, v. 27 , no. 10 , p. $1484-1500$.

Berg, N., McGurk, B., and Calhoun, R., 1997, Hydrology and Land Use Effects on the Hanalei National Wildlife Refuge, Kauai, Hawaii, Final Report, Interagency Agreement 14-480001-94588: U.S. Department of Agriculture Forest Service, Pacific Southwest Research Station, 62 p.

Blumenstock, D.I., and Price, S., 1967, Climates of Hawai' $i$, in Climates of the States, Climatology of the United States: U.S. Department of Commerce, Washington, D.C., no. 60-51, p. 27.

Brouwer, C., and Heibloem, M., 1986, Irrigation Water Management, Training Manual No. 3; Irrigation Water Needs: Food and Agriculture Organization of the United Nations, 98 p.

Brutsaert, W., 2005, Hydrology, An Introduction: Cambridge, UK, Cambridge University Press, 605 p.

County of Maui Department of Water Supply, 2016, Maui Island Water Use and Development Plan, Background, Existing Resources and Uses, and Future Demands, Preliminary Information - Subject to Change:, 210 p., accessed November 13, 2017, at https://www.mauicounty.gov/2051/Maui-IslandWater-Use-Development-Plan.

De la Pena, R., and Melchor, F., 1984, Water use and efficiency in lowland taro production, in sixth Symposium of the International Society for Tropical Root Crops, Feb. 21-26, 1983, Proceedings: Lima, Peru, Society for Tropical Root Crops.

DeLay, J., 2005, Canopy water balance of an elfin cloud forest at Alakahi, Hawai'i: University of Hawai'i at Mānoa, Honolulu, Hawai'i, Masters Thesis, 78 p., 19 figs.

DeLay, J.K., and Giambelluca, T.W., 2010, History of cloud water interception research in Hawai' $i$, in Bruijnzeel, L., Scatena, F., and Hamilton, L. eds., Tropical Montane Cloud Forests: Science for Conservation and Management, Cambridge, UK, Cambridge University Press, p. 332-341.
Diaz, H.F., Giambelluca, T.W., and Eischeid, J.K., 2011, Changes in the vertical profiles of mean temperature and humidity in the Hawaiian Islands: Global and Planetary Change, v. 77, no. 1, p. 21-25.

Dorrance, W.H., and Morgan, F., 2000, Sugar Islands-The 165-year Story of Sugar in Hawai'i: Honolulu, Hawaii, Mutual Publishing, $282 \mathrm{p}$.

Ekern, P.C., 1964, Direct interception of cloud water on Lanaihale, Hawaii: Soil Science Society of America Journal, v. 28, p. 419-421.

Elison Timm, O., 2017, Future warming rates over the Hawaiian Islands based on elevation-dependent scaling factors: International Journal of Climatology, v. 37, p. 1093-1104.

Elison Timm, O., Giambelluca, T.W., and Diaz, H.F., 2015, Statistical downscaling of rainfall changes in Hawai' $i$ based on the CMIP5 global model projections: Journal of Geophysical Research; Atmospheres, v. 120, no. 1, p. 92-112.

Engott, J.A., 2011, A water-budget model and assessment of groundwater recharge for the Island of Hawai' $i$ : U.S. Geological Survey Scientific Investigations Report 2011-5078, 53 p., accessed at http://pubs.usgs.gov/sir/2011/5078/.

Engott, J.A., Johnson, A.G., Bassiouni, M., Izuka, S.K., and Rotzoll, K., 2017, Spatially distributed groundwater recharge for 2010 land cover estimated using a water-budget model for the Island of O‘ahu, Hawai'i (ver 2.0, December 2017): U.S. Geological Survey Scientific Investigations Report 20155010, 49 p., accessed at https://pubs.er.usgs.gov/publication/ $\operatorname{sir} 20155010$.

Engott, J.A., and Vana, T.T., 2007, Effects of agricultural landuse changes and rainfall on ground-water recharge in Central and West Maui, Hawai i, 1926-2004: U.S. Geological Survey Scientific Investigations Report 2007-5103, 56 p., accessed at https://pubs.usgs.gov/sir/2007/5103/.

Frazier, A.G., and Giambelluca, T.W., 2017, Spatial trend analysis of Hawaiian rainfall from 1920 to 2012: International Journal of Climatology, v. 37, no. 5, p. 2522-2531.

Frazier, A.G., Giambelluca, T.W., Diaz, H.F., and Needham, H.L., 2016, Comparison of geostatistical approaches to spatially interpolate month-year rainfall for the Hawaiian Islands: International Journal of Climatology, v. 36, no. 3, p. 1459-1470.

Gash, J.H.C., Lloyd, C.R., and Lachaud, G., 1995, Estimating sparse forest rainfall interception with an analytical model: Journal of Hydrology, v. 170, no. 1-4, p. 79-86.

Gaskill, T.G.R., 2004, Hydrology of forest ecosystems in the Honouliuli Preserve - implications for groundwater recharge and watershed restoration: Honolulu, Hawaii, University of Hawaii at Mānoa, PhD Dissertation, 177 p. 
Giambelluca, T.W., Chen, Q., Frazier, A.G., Price, J.P., Chen, Y.-L., Chu, P.-S., Eischeid, J.K., and Delparte, D.M., 2013, Online Rainfall Atlas of Hawai' $i$ : Bulletin of the American Meteorological Society, v. 94, no. 3, p. 313-316.

Giambelluca, T.W., DeLay, J.K., Nullet, M.A., Scholl, M.A., and Gingerich, S.B., 2011, Canopy water balance of windward and leeward Hawaiian cloud forests on Haleakalā, Maui, Hawai'i: Hydrological Processes, v. 25, p. 438-447.

Giambelluca, T.W., Diaz, H.F., and Luke, M.S.A., 2008, Secular temperature changes in Hawaii: Geophysical Research Letters, v. 35, p. L12702.

Giambelluca, T.W., X. Shuai, M.L. Barnes, R.J. Alliss, R.J. Longman, T. Miura, Q. Chen, A.G. Frazier, R.G. Mudd, L. Cuo, and A.D. Businger. 2014. Evapotranspiration of Hawai'i. Final report submitted to the U.S. Army Corps of EngineersHonolulu District, and the Commission on Water Resource Management, State of Hawai'i.

Gingerich, S.B., 2008, Ground-water availability in the Wailuku area, Maui, Hawai'i: U.S. Geological Survey Scientific Investigations Report 2008-5236, 95 p., accessed at https:// pubs.usgs.gov/sir/2008/5236/.

Gingerich, S.B., and Engott, J.A., 2012, Groundwater availability in the Lahaina District, west Maui, Hawai' $i$ : U.S. Geological Survey Scientific Investigations Report 2012-5010, 90 p., accessed at https://pubs.usgs.gov/sir/2012/5010/.

Gingerich, S.B., and Oki, D.S., 2000, Ground water in Hawaii: U.S. Geological Survey Fact Sheet 126-00, 6 p., accessed at https://pubs.usgs.gov/fs/2000/126/.

Graham, L.P., Hagemann, S., Jaun, S., and Beniston, M., 2007, On interpreting hydrological change from regional climate models: Climatic Change, v. 81, no. 1, p. 97-122.

Hay, L.E., Wilby, R.L., and Leavesley, G.H., 2000, A comparison of delta change and downscaled GCM scenarios for three mountainous basins in the United States: Journal of the American Water Resources Association, v. 36, p. 387-397.

Heath, J.A., and Huebert, B.J., 1999, Cloudwater deposition as a source of fixed nitrogen in a Hawaiian montane forest: Biogeochemistry, v. 44, no. 2, p. 119-134.

Hevesi, J.A., Flint, A.L., and Flint, L.E., 2002, Preliminary estimates of spatially distributed net infiltration and recharge for the Death Valley region, Nevada-California: U.S. Geological Survey Water-Resources Investigations Report 02-4010, 36 p.

Hunt, C.D., 2004, Ground-water quality and its relation to land use on Oahu, Hawaii, 2000-01: U.S. Geological Survey Water Resources Investigations Report 03-4305, 76 p., accessed at https://pubs.usgs.gov/wri/wri034305/.
Intergovernmental Panel on Climate Change, 2000, A Special Report of Working Group III in Nakicenovic, N. and Swart, R., eds., Emissions Scenarios: Cambridge, UK, Cambridge University Press, 570 p.

Intergovernmental Panel on Climate Change, 2007, Climate Change 2007-The Physical Science Basis in Solomon, S., Qin, D., Manning, M., Chen, Z., Marquis, M., Averyt, K.B., Tignor, M, and Miller, H.L., eds., Working Group I Contribution to the Fourth Assessment Report of the Intergovernmental Panel on Climate Change: Cambridge, UK and New York USA Cambridge University Press, 996 p.

Intergovernmental Panel on Climate Change, 2014, Climate Change 2014 Synthesis Report in Core Writing Team, Pachauri, R.K. and Meyer, L.A., eds. Contribution of Working Groups I, II and III to the Fifth Assessment Report of the Intergovernmental Panel on Climate Change: Geneva, Switzerland, Intergovernmental Panel on Climate Change, $151 \mathrm{p}$.

Intergovernmental Panel on Climate Change, 2018, Summary for Policymakers, in V.,Masson-Delmotte, V., Zhai, P., Pörtner, H.-O., Roberts, D., Skea, J., Shukla, P.R., Pirani, A., Moufouma-Okia, W., Péan, C., Pidcock, R., Connors, S., Matthews, J.B.R., Chen, Y., Zhou, X., and others eds., Global Warming of $1.5^{\circ} \mathrm{C}$-An Intergovernmental Panel on Climate Change Special Report on the impacts of global warming of $1.5^{\circ} \mathrm{C}$ above pre-industrial levels and related global greenhouse gas emission pathways, in the context of strengthening the global response to the threat of climate change, sustainable development, and efforts to eradicate poverty: Geneva, Switzerland, World Meteorological Organization, p. 32.

Izuka, S.K., Engott, J.A., Rotzoll, K., Bassiouni, M., Johnson, A.G., Miller, L.D., and Mair, A., 2018, Volcanic aquifers of Hawai' $\mathrm{i}$-Hydrogeology, water budgets, and conceptual models (ver. 2.0, March 2018): U.S. Geological Survey Scientific Investigations Report 2015-5164, 158 p., accessed at https://pubs.er.usgs.gov/publication/sir20155164.

Johnson, A.G., 2017, Mean annual water-budget components for the Island of Maui, Hawaii, for average climate conditions, 1978-2007 rainfall and 2010 land cover (version 2.0): U.S. Geological Survey data release, accessed at https:/doi. org/10.5066/F7K64H14.

Johnson, A.G., Engott, J.A., Bassiouni, M., and Rotzoll, K., 2018, Spatially distributed groundwater recharge estimated using a water-budget model for the Island of Maui, Hawai'i, 1978-2007 (ver 2.0, February 2018): U.S. Geological Survey Scientific Investigations Report 2014-5168, 53 p., accessed at https://doi.org/10.3133/sir20145168.

Juvik, J.O., and Ekern, P.C., 1978, A Climatology of Mountain Fog on Mauna Loa, Hawaii Island, Technical Report 118: Water Resources Research Center, University of Hawaii, 63 p. 
Juvik, J.O., and Nullet, D., 1995, Relationships Between Rainfall, Cloud-Water Interception, and Canopy Throughfall in a Hawaiian Montane Forest, in Hamilton, L.S., Juvik, J.O., and Scatena, F.N., eds., Tropical Montane Cloud Forests: New York, Springer US, p. 165-182.

Keener, V., Helweg, D., Asam, S., Balwani, S., Burkett, M., Fletcher, C., Giambelluca, T., Grecni, Z., Nobrega-Olivera, M., Polovina, J., and Tribble, G., 2018, Hawai' $i$ and U.S.Affiliated Pacific Islands, in Reidmiller, D.R., Avery, C.W., Easterling, D.R., Kunkel, K.E., Lewis, K.L.M., Maycock, T.K., and Stewart, B.C., eds., Impacts, Risks, and Adaptation in the United States: Washington, D.C., Fourth National Climate Assessment, Volume II, U.S. Global Change Research Program, p. 1242-1308.

Lauer, A., Zhang, C., Elison-Timm, O., Wang, Y., and Hamilton, K., 2013, Downscaling of climate change in the Hawaii region using CMIP5 results: on the choice of the forcing fields: Journal of Climate, v. 26, no. 24, p. 10006-10030.

Leavesley, G.H., Lichty, R.W., Troutman, B.M., and Saindon, L.G., 1983, Precipitation runoff modeling systemUser's manual: U.S. Geological Survey Water-Resources Investigations Report 83-4238, 207 p.

Leta, O.T., El-Kadi, A.I., and Dulai, H., 2017, Implications of Climate Change on Water Budgets and Reservoir Water Harvesting of Nuuanu Area Watersheds, Oahu, Hawaii: Journal of Water Resources Planning and Management, v. 143 , no. 11 , p. 05017013.

Leta, O.T., El-Kadi, A.I., and Dulai, H., 2018, Impact of Climate Change on Daily Streamflow and Its Extreme Values in Pacific Island Watersheds: Sustainability, v. 10, no. 6, 22 p.

Leta, O.T., El-Kadi, A.I., Dulai, H., and Ghazal, K.A., 2016, Assessment of climate change impacts on water balance components of Heeia watershed in Hawaii: Journal of Hydrology: Regional Studies, v. 8, no. Supplement C, p. 182-197.

Macdonald, G.A., Abbott, A.T., and Peterson, F.L., 1983, Volcanoes in the sea-the geology of Hawaii, 2nd edition: Honolulu, University of Hawai'i Press, 517 p.

Mair, A., 2018, Land-Cover Map for the Island of Maui, Hawaii, circa 2017 (version 1.2, November 2018): U.S. Geological Survey data release, accessed at https://doi.org/10.5066/F7DF6PPB.

Mair, A., 2019a, Mean annual water-budget components for the Island of Maui, Hawaii, for average climate conditions, 1978-2007 rainfall and 2017 land cover: U.S. Geological Survey data release, accessed at https://doi.org/10.5066/ P91WSOFO.
Mair, A., 2019b, Mean annual water-budget components for the Island of Maui, Hawaii, for projected climate conditions, CMIP3 A1B 2080-99 scenario climate and 2017 land cover: U.S. Geological Survey data release, accessed at https://doi.org/10.5066/P9437T2F

Mair, A., 2019c, Mean annual water-budget components for the Island of Maui, Hawaii, for projected climate conditions, CMIP5 RCP8.5 2071-99 scenario climate and 2017 land cover: U.S. Geological Survey data release, accessed at https://doi.org/10.5066/P98W9ABX

Melrose, J., Perroy, R., and Cares, S., 2016, Statewide Agricultural Land Use Baseline 2015: University of Hawaii at Hilo, prepared for Hawaii Department of Agriculture, 101 p., accessed at http://hdoa.hawaii.gov/wp-content/uploads/2016/02/ StateAgLandUseBaseline2015.pdf.

Miles, K., 1931, Report on study of water requirements of taro in Hanapēpē Valley, cooperative study by the Territory of Hawai' $i$ and McBryde Sugar Company: 'Ele'ele, Hawai'i, 52 p.

National Oceanic and Atmospheric Administration, 2015, C-CAP Land Cover, Maui, Hawaii: NOAA's Ocean Service, Office for Coastal Management, accessed September 28, 2018, at http://coast.noaa.gov/ccapftp/.

Natural Resources Conservation Service, 2006, Soil survey geographic (SSURGO) database for the island of Maui: U.S. Department of Agriculture, Natural Resources Conservation Service.

Oki, D.S., 2002, Reassessment of ground-water recharge and simulated ground-water availability for the Hawi area of north Kohala, Hawaii: U.S. Geological Survey Water-Resources Investigations Report 02-4006, 62 p., accessed at https://pubs.usgs.gov/wri/wri02-4006/.

Oki, D.S., 2004, Trends in streamflow characteristics at long-term gaging stations, Hawaii: U.S. Geological Survey Scientific Investigations Report 2004-5080, 120 p., accessed at https://pubs.usgs.gov/sir/2004/5080/.

Rea, A., and Skinner, K.D., 2012, Geospatial datasets for watershed delineation and characterization used in the Hawaii StreamStats web application: U.S. Geological Survey Data Series 680, 20 p., accessed at http://pubs.er.usgs.gov/publication/ds680.

van Roosmalen, L., Christensen, J.H., Butts, M.B., Jensen, K.H., and Refsgaard, J.C., 2010, An intercomparison of regional climate model data for hydrological impact studies in Denmark: Journal of Hydrology, v. 380, no. 3-4, p. 406-419.

van Roosmalen, L., Christensen, B.S.B., and Sonnenborg, T.O., 2007, Regional differences in climate change impacts on groundwater and stream discharge in Denmark: Vadose Zone Journal, v. 6, no. 3, p. 554. 
van Roosmalen, L., Sonnenborg, T.O., and Jensen, K.H., 2009, Impact of climate and land use change on the hydrology of a large-scale agricultural catchment: Water Resources Research, v. 45, no. 7, 18 p.

van Roosmalen, L., Sonnenborg, T.O., Jensen, K.H., and Christensen, J.H., 2011, Comparison of hydrological simulations of climate change using perturbation of observations and distribution-based scaling: Vadose Zone Journal, v. 10, no. 1, p. 136-150.

Safeeq, M., and Fares, A., 2012, Hydrologic response of a Hawaiian watershed to future climate change scenarios: Hydrological Processes, v. 26, no. 18, p. 2745-2764.

Safeeq, M., and Fares, A., 2014, Interception losses in three non-native Hawaiian forest stands: Hydrological Processes, v. 28 , no. 2 , p. $237-254$.

Sanderson, M., ed., 1993, Prevailing Trade Winds: Climate and Weather in Hawaii: Honolulu, University of Hawaii Press, $156 \mathrm{p}$.

Scholl, M.A., Giambelluca, T.W., Gingerich, S.B., Nullet, M.A., and Loope, L.L., 2007, Cloud water in windward and leeward mountain forests-The stable isotope signature of orographic cloud water: Water Resources Research, v. 43, p. W12411.

Schroeder, T.A., 1993, Climate controls, in Sanderson, M. ed., Prevailing Trade Winds: Weather and Climate in Hawaii: Honolulu, University of Hawaii Press, p. 12-36.

State of Hawaii, 2010, Aquifer Boundaries for the Island of Maui, Hawaii: Department of Land and Natural Resources, accessed November 14, 2017, at http://planning.hawaii.gov/ gis/download-gis-data/.

Stearns, H.T., and Macdonald, G.A., 1942, Geology and Ground-water Resources of the Island of Maui, Hawaii, Bulletin 7: Territory of Hawaii, Division of Hydrography, $344 \mathrm{p}$.

Strauch, A.M., Giardina, C.P., MacKenzie, R.A., Heider, C., Giambelluca, T.W., Salminen, E., and Bruland, G.L., 2017, Modeled Effects of Climate Change and Plant Invasion on Watershed Function Across a Steep Tropical Rainfall Gradient: Ecosystems, v. 20, no. 3, p. 583-600.

Takahashi, M., Giambelluca, T.W., Mudd, R.G., DeLay, J.K., Nullet, M.A., and Asner, G.P., 2011, Rainfall partitioning and cloud water interception in native forest and invaded forest in Hawai'i Volcanoes National Park: Hydrological Processes, v. 25 , p. $448-464$.

Tanji, M., 2016, Operations winding down at HC\&S: The Maui News, accessed at https://www.mauinews.com/news/localnews/2016/12/operations-winding-down-at-hcs/.
Taylor, K.E., Stouffer, R.J., and Meehl, G.A., 2012, An Overview of CMIP5 and the Experiment Design: Bulletin of the American Meteorological Society, v. 93, no. 4, p. 485-498.

Thornthwaite, C.W., and Mather, J.R., 1955, The water balance: Centerton, New Jersey., Laboratory of Climatology, Publications in climatology, v. 8, p. 1-104.

Timm, O., and Diaz, H.F., 2009, Synoptic-statistical approach to regional downscaling of IPCC twenty-first century climate projections - seasonal rainfall over the Hawaiian Islands: Journal of Climate, v. 22, p. 4261-4280.

Timm, O.E., Diaz, H.F., Giambelluca, T.W., and Takahashi, M., 2011, Projection of changes in the frequency of heavy rain events over Hawaii based on leading Pacific climate modes: Journal of Geophysical Research, v. 116, p. D04109.

Tribble, G., 2008, Ground water on tropical pacific islands - understanding a vital resource: U.S. Geological Survey Circular 1312, 35 p., accessed at https://pubs.usgs.gov/ circ/1312/.

University of Hawai' i, 2008, Hawaii Agricultural Water Use and Development Plan, prepared for State of Hawaii Department of Agriculture: College of Tropical Agriculture and Human Resources, Department of Natural Resources and Environmental Management, $135 \mathrm{p}$.

U.S. Geological Survey, 2013, LANDFIRE Existing Vegetation Type layer for Hawaii (2013, November - last update): Wildland Fire Science, Earth Resources Observation and Science Center, U.S. Geological Survey, available at http://landfire.cr.usgs.gov/viewer/.

Viessman, W., and Lewis, G.L., 2003, Introduction to Hydrology, Fifth Edition: Upper Saddle River, New Jersey, Prentice Hall, Pearson Education, Incorporated, $624 \mathrm{p}$.

Watson, L.J., ed., 1964, Observations made with respect to irrigation and growth of taro at certain patches at Waiāhole and Kahaluu: Honolulu, Hawai' $i$, City \& County of Honolulu Board of Water Supply Water Resources Division, in Reppun v. Board of Water Supply: variously paged.

Westenbroek, S.M., Engott, J.A., Kelson, V.A., and Hunt, R.J., 2018, SWB Version 2.0 - A soil-water-balance code for estimating net infiltration and other water-budget components: U.S. Geological Survey Techniques and Methods, book 6, chap. A59, 118 p., accessed at https://doi.org/10.3133/ tm6A59.

Westenbroek, S.M., Kelson, V.A., Dripps, W.R., Hunt, R.J., and Bradbury, K.R., 2010, SWB-A modified ThornthwaitheMather Soil-Water-Balance code for estimating groundwater recharge: U.S. Geological Survey Techniques and Methods 6A31, 60 p., accessed at https://pubs.usgs.gov/tm/tm6-a31/. 
Whittier, R.B., and El-Kadi, A.I., 2014, Human and environmental risk ranking of onsite sewage disposal systems for the Hawaiian Islands of Kauai, Maui, Molokai, and Hawaii: Department of Geology and Geophysics, University of Hawaii, 253 p.

Wilby, R.L., Hay, L.E., Gutowski, W.J., Arritt, R.W., Takle, E.S., Pan, Z., Leavesley, G.H., and Clark, M.P., 2000, Hydrological responses to dynamically and statistically downscaled climate model output: Geophysical Research Letters, v. 27, no. 8, p. 1199-1202.

Wilson Okamoto Corporation, 2008, Hawaii Water Plan, Water Resource Protection Plan: prepared for State of Hawaii, Department of Land and Natural Resources, Commission on Water Resource Management, $537 \mathrm{p}$.
Zhang, C., Wang, Y., Hamilton, K., and Lauer, A., 2016a, Dynamical Downscaling of the Climate for the Hawaiian Islands, Part I—Present Day: Journal of Climate, v. 29, no. 8, p. 3027-3048.

Zhang, C., Wang, Y., Hamilton, K., and Lauer, A., 2016b, Dynamical Downscaling of the Climate for the Hawaiian Islands, Part II-Projection for the Late Twenty-First Century: Journal of Climate, v. 29, no. 23, p. 8333-8354.

Zhang, C., Wang, Y., Lauer, A., and Hamilton, K., 2012, Configuration and evaluation of the WRF model for the study of Hawaiian regional climate: Monthly Weather Review, v. 140, no. 10 , p. 3259-3277. 
Menlo Park Publishing Service Center, California

Manuscript approved for publication June 25, 2019

Edited by Phil A. Frederick

Layout and design by Cory D. Hurd 


\section{$\frac{\mathbb{2}}{3}$}

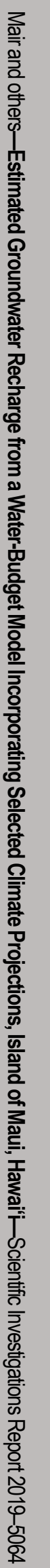

